Louisiana State University

LSU Digital Commons

$8-1-2020$

\title{
Provenance of Thal Desert sand: Focused erosion in the western Himalayan syntaxis and foreland-basin deposition driven by latest Quaternary climate change
}

\author{
Eduardo Garzanti \\ University of Milano - Bicocca \\ Wendong Liang \\ University of Milano - Bicocca \\ Sergio Andò \\ University of Milano - Bicocca \\ Peter D. Clift \\ Louisiana State University \\ Alberto Resentini \\ University of Milano - Bicocca
}

See next page for additional authors

Follow this and additional works at: https://digitalcommons.Isu.edu/geo_pubs

\section{Recommended Citation}

Garzanti, E., Liang, W., Andò, S., Clift, P., Resentini, A., Vermeesch, P., \& Vezzoli, G. (2020). Provenance of Thal Desert sand: Focused erosion in the western Himalayan syntaxis and foreland-basin deposition driven by latest Quaternary climate change. Earth-Science Reviews, 207 https://doi.org/10.1016/ j.earscirev.2020.103220

This Article is brought to you for free and open access by the Department of Geology and Geophysics at LSU Digital Commons. It has been accepted for inclusion in Faculty Publications by an authorized administrator of LSU Digital Commons. For more information, please contact ir@lsu.edu. 
Authors

Eduardo Garzanti, Wendong Liang, Sergio Andò, Peter D. Clift, Alberto Resentini, Pieter Vermeesch, and Giovanni Vezzoli 


\section{Provenance of Thal Desert sand: focused erosion in the western}

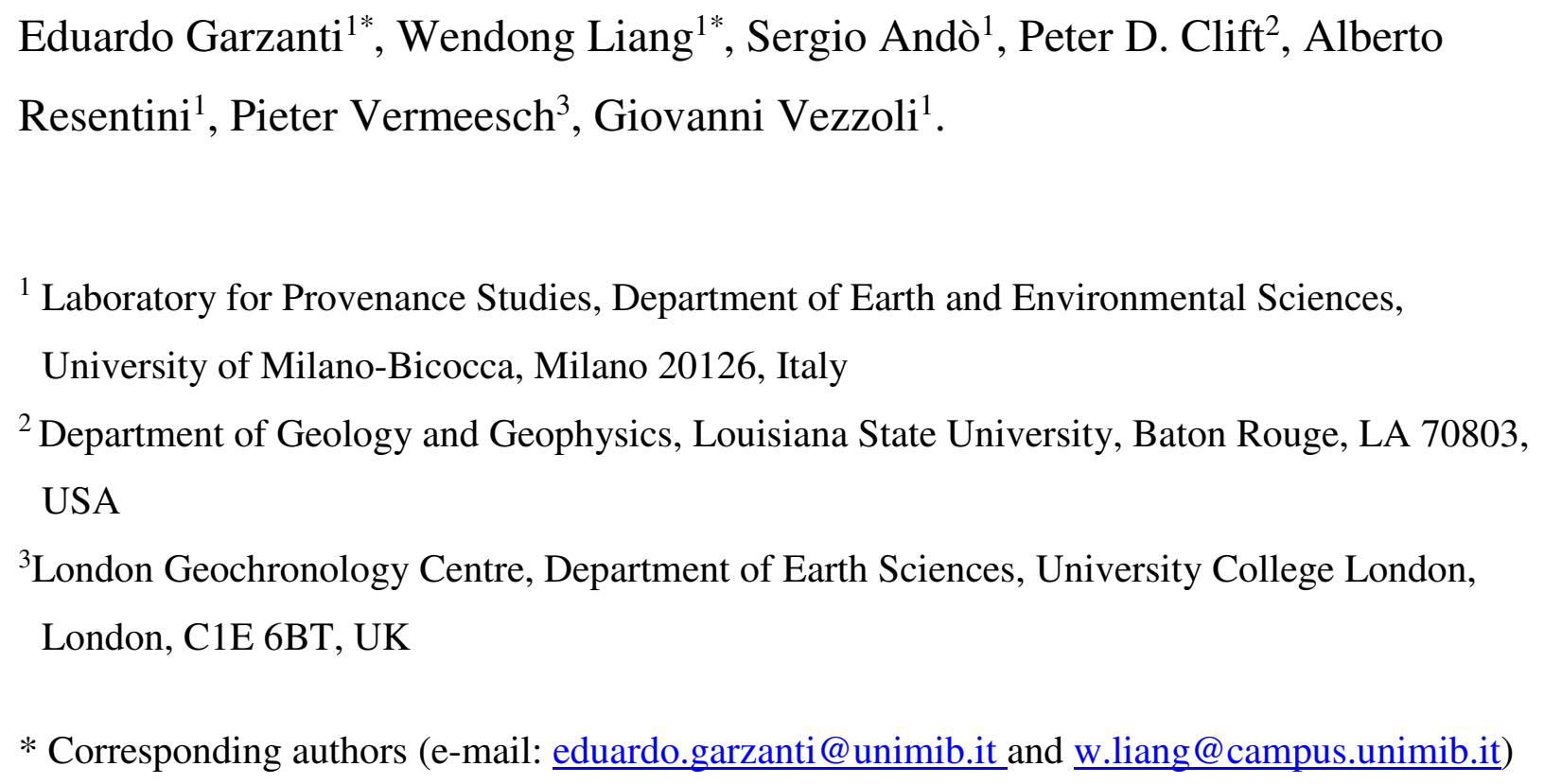

Keywords: Sand petrography and geochemistry; Detrital-zircon geochronology; Variability of ENd values; Focused erosion; Himalaya-Karakorum; Kohistan Arc; Indus River, Delta, and Fan.

\section{Highlights:}

The Thal Desert is an inland archive of Indus sand from the western Himalaya syntaxis

Sand stored in the Thal dunefield reveals major detrital supply from the Kohistan arc

High variability of $\varepsilon_{\mathrm{Nd}}$ values is controlled by minimal changes in monazite content

The Thal Desert formed in a dry landscape between the LGM and the wet early Holocene 


\begin{abstract}
As a latest Pleistocene repository of Indus River sand at the entry point to the Himalayan foreland basin, the Thal dune field in northern Pakistan stores crucial information that can be used to reconstruct the erosional evolution of the Himalayan-Karakorum orogen and the changes in the foreland-basin landscape that took place between the Last Glacial Maximum and the early Holocene. This comprehensive provenance study of Thal Desert sand integrates previously existing petrographic, heavy-mineral, mineral-chemical, isotopic, and geochronological databases with original bulksediment geochemistry, zircon-age, and Nd-isotope data. Dune sand is low in quartz and rich in feldspars, volcanic, metavolcanic and metabasite grains, contains a very rich transparent heavymineral suite including hypersthene and common zircon grains dated as Late Cretaceous to early Paleogene, and is characterized by high $\mathrm{Mg}, \mathrm{Sc}, \mathrm{V}, \mathrm{Co}, \mathrm{Ni}, \mathrm{Cu}$ concentrations and by $\varepsilon_{\mathrm{Nd}}$ values as high as -3.5 . Together, these data indicate that $\sim 40 \%$ of Thal dune sand was supplied by erosion of the Kohistan arc, a proportion that far exceeds the one assessed for modern Upper Indus sand. Greater detrital supply from the Kohistan arc indicates notably different conditions of sediment generation, during a period in which the sediment-transport capacity of the Upper Indus in the dry lowlands was reduced and volumes of sand were extensively reworked by wind and accumulated in dune fields across the foreland basin. In the early Holocene, the renewed strength of the South Asian monsoon and consequently markedly increased water and sediment discharge led to incision of the Thal and Thar dune fields by the Indus River and its Punjab tributaries draining the Himalayan front directly hit by heavy monsoonal rains.
\end{abstract}




\section{Introduction}

The western Himalaya and Karakorum Ranges (in Sanskrit: hima = snow, alayah = abode; in Uyghur Turkic: $k a r a=$ black, korum $=$ gravel) drained by the Indus River provide a spectacular example of an orogenic belt produced by continental collision (Searle, 2013). Ongoing indentation between the Indian and Asian continents since 60-58 Ma (Garzanti et al., 1987; Beck et al., 1995; Hu et al., 2015; Najman et al., 2017) and accelerated rock uplift associated with ultra-rapid exhumation of crystalline basement rocks since the Neogene (Rolland et al., 2001; Zeitler et al., 2001) resulted in extreme relief and erosion rates around the western Himalayan syntaxis (Burbank et al., 1996a; Shroder and Bishop, 2000).

An important contribution to a better understanding of the tectonic growth and erosional evolution of such a complex orogenic region, where geological processes are so intense, is given by provenance analysis of detritus carried by the precursors of the Indus River and stored through time in adjacent sedimentary basins (Critelli et al., 1990; Garzanti et al., 1996; Qayyum et al., 1997; Clift et al., 2001). Numerous studies of Himalayan foreland-basin strata have been devoted to understanding how the Indus River system has formed and evolved (e.g., Cerveny et al., 1989; Critelli and Garzanti, 1994; Najman et al., 2003; Downing and Lindsay 2005; Roddaz et al., 2011; Chirouze et al., 2015; Zhuang et al., 2015). Crucial information is stored in the thick sediment pile accumulated in the Indus Fan, cored so far around its southeastern and western edges during Ocean Drilling Program (ODP) Leg 23 in 1972 (Jipa and Kidd, 1974; Mallik, 1978; Suczek and Ingersoll, 1985) and more recently during International Ocean Discovery Program (IODP) Expedition 355 to the Laxmi Basin in 2014 (Clift et al., 2019). Turbidites of proven Himalayan provenance recovered from both ODP Leg 23 and IODP Expedition 355 are however mostly late Miocene or younger in age, and much thus remains to be understood regarding earlier phases of orogenic erosion (Pandey et al., 1996). 
While plunging deeper in time, paleogeographic reconstructions have to face an increasing number

of unknowns, not only because of subsequent accretion and exhumation of diverse geological units but also because repeated modifications of the drainage system have occurred even in the recent past (e.g., Burbank et al., 1996b; Clift et al., 2012). Moreover, the compositional fingerprints of ancient siliciclastic strata reflect a distorted image of the lithological structure of source terranes because of selective diagenetic dissolution of less durable detrital components (Garzanti, 2019a).

The safest way to proceed is to start from the knowledge of the modern sediment-routing system, where everything is in principle known or knowable (Garzanti et al., 2005; Alizai et al., 2011, 2016; East et al., 2015; Zhuang et al., 2018) and to extend that knowledge to the recent and less recent past (Clift et al., 2010; Garzanti et al., 2020). In this regard, a particularly interesting repository of clastic sediments is represented by the Thal Desert, a small dune field occupying a dry area just south of the Salt Range, the Pliocene thrust belt representing the front of the Himalayan orogen in central northern Pakistan (Fig. 1).

Thal Desert dunes consist of wind-reworked sediment entirely supplied by the Indus River upstream of the orogenic front (henceforth named "Upper Indus") that provides us with a precise compositional signature of detritus dominantly generated by the rapid erosion of the western Himalayan syntaxis in the latest Quaternary. The Jhelum River and other large left-bank tributaries draining the southern flank of the Himalaya and flowing across the Punjab plains convey their sediments to the Indus River only downstream of the Thal Desert, and their contribution to this dune field is negligible, as documented by the peculiar compositional signatures of eolian sands (Liang et al., 2019). On the contrary, it is the Thal dunes that, eroded all along the western side of the desert, contribute sand to the Jhelum River and to the Panjnad River downstream (Fig. 2; Garzanti et al., 2005).

The Upper Indus compositional signature preserved in the Thal dune field is exempt from any anthropic modification that had occurred in the region (e.g., Tarbela Dam) and can be compared with sand composition in the Lower Indus River, Delta, and Fan. This allows us to calculate the 
relative amount of sediment shed from diverse upstream sources around the syntaxis versus those derived from the southern side of the Himalaya and/or the Sulaiman-Kirthar Ranges of western Pakistan. By applying the same principle to older deposits, we can explore how erosional patterns have varied through time and reveal how the interplay between tectonic and climatic processes has governed the shift of erosional foci in the past (Clift, 2017; Clift et al., 2019).

The aim of the present study is to document in detail the diverse compositional fingerprints of Thal Desert sand by applying multiple analytical techniques, including high-resolution bulk-sediment petrography and geochemistry, heavy minerals and heavy-mineral chemistry, detrital-zircongeochronology, and $\mathrm{Nd}$ isotopes. This integrated dataset is employed to discuss the erosional evolution of the western Himalaya and the sedimentary evolution of the Indus River, Delta and Fan through the latest Cenozoic.

\section{The Thal Desert}

Pakistan is an arid to semi-arid subtropical country including the large Thar Desert $\left(\sim 175,000 \mathrm{~km}^{2}\right)$ straddling the political border with India in the southeast (Singh et al., 1990; Enzel et al., 1999; Singhvi and Kar, 2004; Singhvi et al., 2010; East et al., 2015). In the north, the much smaller and much less well studied, $300 \mathrm{~km}$-long and $100 \mathrm{~km}$-wide Thal Desert is located between about $30^{\circ}$ and $32^{\circ} 30^{\prime} \mathrm{N}$ and between about $71^{\circ}$ and $72^{\circ} \mathrm{E}$ (Fig. 1). This triangular-shaped desert occupies the Thal or Sind-Sagar Doab (in Farsi: $d o a b=$ two waters, or land between two adjacent rivers), the region extending between the course of the Indus River in the west and the Punjab plain in the east, built by the Jhelum, Chenab, Ravi, and Beas-Sutlej Rivers (in Farsi: punj $a b=$ five waters, or land of the five rivers).

The Thal Desert, located between the Indus and Jhelum Rivers, is delimited by the Salt Range foothills in the north, whereas the Indus floodplain is bounded by the Sulaiman Range in the west. Exposed in the Salt Range are Neoproterozoic evaporites overlain by a fossiliferous Cambrian to Cenozoic succession (Shah, 1977). The Sulaiman fold-thrust belt includes largely shelfal upper 
Paleozoic to Eocene strata, Neogene molasse, and deep-water turbidites underlain by ophiolitic complexes (Jadoon et al., 1994). The Punjab plains are underlain by up to $450 \mathrm{~m}$ of Quaternary alluvium and eolian deposits lying over semiconsolidated Cenozoic rocks or directly over Precambrian crystalline basement, which crops out in the Kirana Hills straddling the Chenab River course and represents the topographic culmination of the NW/SE-trending Delhi-Sargodha ridge (Greenman et al., 1967; Kadri, 1995).

\subsection{Geomorphology}

Different physiographic units can be distinguished in the Thal Desert, which lies at altitudes above sea-level decreasing from $\sim 200 \mathrm{~m}$ in the north to $\sim 120 \mathrm{~m}$ in the south. The piedmont area transitional to the Salt Range foothills hosts alluvial fans consisting of detritus reworked and deposited during sheet floods, and fining downstream over distances of $\sim 10 \mathrm{~km}$. The desert area to the south, covered by low sand dunes or rolling sand plains alternating with narrow valleys of cultivable land, is underlain by Quaternary fluvial and eolian deposits more than 350 m-thick in southern areas, but even thicker in the central part of the desert (Nickson et al., 2005). The recent finding of Mesolithic artefacts at the top of sand dunes indicates that the accumulation of eolian sand pre-dates the Holocene (Biagi et al., 2019). The last episode of dune growth may thus be related to large sediment fluxes released during glacier retreat following the Last Glacial Maximum (LGM) in the latest Pleistocene (Clift and Giosan, 2014).

The underlying alluvium mostly consists of laterally continuous bodies of fine to coarse sand, with minor gravel and isolated mud lenses. Coarser deposits occur in the north closer to the Salt Range, but otherwise the distribution of grain sizes is irregular, largely reflecting original deposition by the constantly shifting paleo-Indus and/or adjacent tributaries. The presently active Indus River floodplain reaches $>20 \mathrm{~km}$ in width in the south. The abandoned floodplain is even wider and includes areas of higher ground. These bar uplands are actively eroded by the Jhelum River in the 
105

northeastern part of the desert, forming up to $10 \mathrm{~m}$-high scarps facing the floodplain (Greenman et al., 1967).

\subsection{Climate}

Summers are very hot in the Thal Desert with average temperatures around $35^{\circ} \mathrm{C}$ in June to July, dropping to $\sim 10^{\circ} \mathrm{C}$ in December to January. Average annual temperatures increase from $\sim 24^{\circ} \mathrm{C}$ in the north and west to $\sim 28^{\circ} \mathrm{C}$ in the south. Most of the region receives less than $350 \mathrm{~mm}$ of rain per year. Annual rainfall progressively decreases from the northern $(617 \mathrm{~mm}$ on average recorded from 1991 to 2013 in the Mianwali meteorological station; Shah and Ahmad, 2015) to the southern edges of the desert (150 mm; Greenman et al., 1967). Today, cold dry winds blow from the north in winter, whereas hot rain-bearing winds blow from the south in summer, with an average speed of several km per hour. Between March and April, hailstorms generated by air turbulence owing to the high temperature difference between the warm surface and the cold upper atmosphere may cause major damage to crop and buildings (Gosal, 2004). In the summer, dust storms are fostered by unsteady thermal conditions and north/south temperature gradients (Hussain et al., 2005).

\subsection{Sediment flux}

The upper course of the Indus River, sourced in the Tibetan Plateau (Fig. 2), drains the Ladakh arc and forearc basin together with the northern side of the Himalaya (Garzanti and Van Haver, 1988; Henderson et al., 2010; Munack et al., 2014). Next, it cuts a deep gorge through the Nanga Parbat crystalline massif and receives detritus from the Karakorum Range and Kohistan Arc (Gaetani et al., 1990; Treloar et al., 1996; Searle et al., 1999; DiPietro and Pogue, 2004; Pêcher et al., 2008; Burg, 2011). Further downstream, it flows across the Himalayan belt and Potwar Plateau (Khan et al., 1997a), where it joins with the Kabul River draining the Hindukush Range (Hildebrand et al., 2001), crosses the Salt Range to eventually reach the lowlands where it flows southward confined between the front of the Sulaiman Range in the west and the Thal Desert in the east (Fig. 1). After closure of the Chashma Dam at the northwestern corner of the Thal Desert in 1971, and of the 
134 Tarbela Dam $200 \mathrm{~km}$ to the north in 1976, most of the sediment carried by the Indus River has $\frac{1}{25}$ been trapped in artificial reservoirs. The suspended sediment flux upstream of Tarbela Dam was

3 136 5 $1 \frac{6}{7} 7$ 8 198 10 gauged as between 176-200 $\cdot 10^{6}$ t/a (Tate and Farquharson, 2000; Ali and De Boer, 2007, 2008) and 218,235 , or $287 \cdot 10^{6}$ t/a (Rehman et al., 1997), whereas estimates of total sediment delivery to the Arabian Sea before the Anthropocene range widely between $100 \cdot 10^{6} \mathrm{t} / \mathrm{a}$ and $675 \cdot 10^{6} \mathrm{t} / \mathrm{a}$ (Ali and De Boer, 2007). Suspended load of the Kabul River was measured as $36.6 \cdot 10^{6}$ t/a (i.e. $17 \pm 3 \%$ that of the Indus upstream of Tarbela Dam; Rehman et al., 1997)

The Thal Doab aquifer, consisting of Quaternary alluvial and eolian deposits with local mud lenses, is recharged rapidly from river water and rainfall. The Indus River and its Punjab tributaries give rise to one of the largest irrigation systems in the world, including the Chashma-Jhelum link canal supplied with Indus waters and built between 1967 and 1971. A network of dams, barrages and canals aims to convert the Thal Desert, where the water table lies between 9 and $0.5 \mathrm{~m}$ from ground surface, into cultivable land (Shah and Ahmad, 2016; Hussain et al., 2017).

The main tributaries joining the Indus River downstream of the Thal Desert drain the Himalayan belt (Fig. 2). Since the 1960 Indus Waters Treaty gave rights to the entire flow of the Indus, Jhelum, and Chenab Rivers to Pakistan, and of the Ravi, Beas, and Sutlej Rivers to India, all Himalayan tributaries of the Punjab have been dammed and linked by canals to irrigate the arid plains and compensate for lost waters in eastern Pakistan. Water discharge dropped sharply from $\geq 100 \mathrm{~km}^{3} / \mathrm{a}$ to $\leq 60 \mathrm{~km}^{3} / \mathrm{a}$, and flow in the Ravi and Sutlej Rivers ceased except during monsoon floods. The Mangla Dam, completed in 1967, has reduced sediment load of the Jhelum River from $45 \cdot 10^{6}$ t/a to $<0.5 \cdot 10^{6}$ t/a (Milliman et al., 1984; Meadows and Meadows, 1999; Giosan et al., 2006a). The main right-bank (western) tributaries of the Indus River draining the Sulaiman Ranges are the Gomal River (basin area 36,000 $\mathrm{km}^{2}$ ), characterized by extreme concentration of suspended solids (42 g/l) and high sediment load (30 $\left.10^{6} \mathrm{t} / \mathrm{a}\right)$, and the Kurram River $\left(3 \cdot 10^{6} \mathrm{t} / \mathrm{a}\right.$; Rehman et al., 1997). Other rivers are minor and mostly flow during flash floods.

\section{Methods}


162 This study, focusing on fine-grained sand of eolian dunes sampled in February 2001 from the Thal

Desert, provides geochemical and geochronological data on sand collected between 2001 and 2011

\subsection{Sand petrography and heavy minerals}

A quartered aliquot of each bulk-sand sample of Thal Desert dunes was impregnated with araldite epoxy, cut into a standard thin section stained with alizarine red to distinguish dolomite and calcite, and analysed by counting 400 points by the Gazzi-Dickinson method (Ingersoll et al., 1984). Sand classification was based on the relative abundance of the three main groups of components $(\mathrm{Q}=$ quartz; F = feldspars; $\mathrm{L}=$ lithic fragments), considered where exceeding 10\%QFL. According to standard use, the less abundant component goes first, the more abundant last (e.g., in a lithofeldspatho-quartzose sand Q > F > L > 10\%QFL; Garzanti, 2019b). Metamorphic grains were classified by protolith composition and metamorphic rank; average rank of rock fragments in each sample was expressed by the metamorphic indices $\mathrm{MI}$ and $\mathrm{MI}^{*}$, ranging respectively from 0 (detritus from sedimentary and volcanic rocks) or 100 (detritus from very low-grade metamorphic rocks) to 500 (detritus from high-grade metamorphic rocks; Garzanti and Vezzoli, 2003). Median grain size was determined in thin section by ranking the samples from coarsest to finest followed by visual comparison with in-house standards sieved at $0.25 \phi$ interval. 
187 Heavy minerals were separated in sodium polytungstate (density $\sim 2.90 \mathrm{~g} / \mathrm{cm}^{3}$ ), using the $63-250 \mu \mathrm{m}$ $\frac{1}{188}$ fraction obtained by sieving and treated with oxalic and acetic acids. Analyses were carried out first

3 189 5 190 8 $19) 1$ 10

by counting 200-225 transparent heavy minerals on grain mounts by the area method (Mange and Maurer, 1992). Next, in order to obtain an accurate estimate of volume percentages of each dense detrital component (Galehouse, 1971), between 275 and 1300 dense grains per sample (700 on average) were point-counted on a polished thin section by semi-automated analysis with a Raman spectrometer (Andò and Garzanti, 2014; Lünsdorf et al., 2019).

Transparent heavy-mineral assemblages, called for brevity "tHM suites" throughout the text, are defined as the spectrum of detrital extrabasinal minerals with density $>2.90 \mathrm{~g} / \mathrm{cm}^{3}$ identifiable under a transmitted-light microscope. According to the volume percentage of transparent heavy minerals in the sample (tHMC), tHM suites are defined as "poor" (tHMC $<1)$, "moderately poor" $(1 \leq$ tHMC < 2), "moderately rich" $(2 \leq \mathrm{tHMC}<5)$, "rich" $(5 \leq \mathrm{tHMC}<10)$, "very-rich" $(10 \leq \mathrm{tHMC}<$ 20), or "extremely rich" (20 < tHMC < 50) (Garzanti and Andò, 2007, 2019). The sum of zircon, tourmaline and rutile over total transparent heavy minerals (ZTR index of Hubert, 1962) estimates the durability of the tHM suite (i.e., extent of recycling; Garzanti, 2017). Detrital components are listed in order of abundance (high to low) throughout the text. The complete petrographic and heavy-mineral datasets are provided in Appendix Tables A2, A3, A4, and A5. Further information on the chemical composition of detrital amphiboles, garnets, epidote-group minerals, and pyroxenes is provided in Liang et al. (2019).

\subsection{U-Pb zircon geochronology}

Detrital zircons were identified by Automated Phase Mapping (Vermeesch et al., 2017) with a Renishaw inVia ${ }^{\mathrm{TM}}$ Raman microscope on the heavy-mineral separates of 14 samples (three from the Thal Desert, two from the Upper Indus, and nine from diverse end-member sources). U-Pb zircon ages were determined at the London Geochronology Centre using an Agilent 7700x LA-ICP-MS (laser ablation-inductively coupled plasma-mass spectrometry) system, employing a NewWave 
214 NWR193 Excimer Laser operated at $10 \mathrm{~Hz}$ with a $20 \mu \mathrm{m}$ spot size and $\sim 2.5 \mathrm{~J} / \mathrm{cm}^{2}$ fluence. No

cathodo-luminescence imaging was done, and the laser spot was always placed "blindly" in the middle of zircon grains in order to treat all samples equally and avoid bias in intersample comparison ("blind-dating approach" as discussed in Garzanti et al., 2018). Data reduction was performed using GLITTER 4.4.2 software (Griffin et al., 2008). We used ${ }^{206} \mathrm{~Pb} /{ }^{238} \mathrm{U}$ and ${ }^{207} \mathrm{~Pb} /{ }^{206} \mathrm{~Pb}$ ages for zircons younger and older than $1100 \mathrm{Ma}$, respectively. No common $\mathrm{Pb}$ correction was applied. Grains with $>+5 /-15 \%$ age discordance were discarded, and 1392 concordant ages were obtained overall. The full geochronological dataset is provided in Appendix B.

\subsection{Bulk chemistry and Nd isotopes}

Chemical analyses of 23 sand samples (four from the Thal Desert, eight from diverse end-member sources, three from the Upper Indus, four from Punjab tributaries, and four from the Lower Indus and Delta) were carried out at Bureau Veritas Mineral Laboratories (Vancouver) on a split aliquot of the 63-2000 $\mu \mathrm{m}$ fraction obtained by wet sieving. Major oxides were determined by ICP-ES and trace elements by ICP-MS, following a lithium metaborate/tetraborate fusion and nitric acid digestion. A separate split was digested in aqua regia and analysed for $\mathrm{Mo}, \mathrm{Cu}, \mathrm{Ag}, \mathrm{Au}, \mathrm{Zn}, \mathrm{Cd}, \mathrm{Hg}$, $\mathrm{Tl}, \mathrm{Pb}, \mathrm{As}, \mathrm{Sb}, \mathrm{Bi}$ and $\mathrm{Se}$, but the concentration of these elements is generally underestimated because of incomplete leaching of refractory minerals. For further information on adopted procedures, geostandards used, and precision for various elements see http://acmelab.com (code LF200). The geochemical dataset is provided in Appendix Table A6.

For each of the four Thal Desert samples, several grams of the bulk sand were powdered to ensure a good average composition. Samples were then dissolved, and the Nd separated using standard column extraction techniques. $\mathrm{Nd}$ isotopic compositions were determined on VG354 mass spectrometer at Woods Hole Oceanographic Institution. ${ }^{143} \mathrm{Nd} /{ }^{144} \mathrm{Nd}$ values were normalized to ${ }^{146} \mathrm{Nd} /{ }^{144} \mathrm{Nd}=0.7219$ and relative to 0.511847 for the La Jolla standard. We calculated the parameter $\varepsilon_{\mathrm{Nd}}$ (DePaolo and Wasserburg, 1976) using a ${ }^{143} \mathrm{Nd} /{ }^{144} \mathrm{Nd}$ value of 0.512638 for the Chondritic 
241 Uniform Reservoir (Hamilton et al., 1983). Original data and a compilation of literature data are provided in Appendix Tables A7 and A8.

\subsection{Statistical/graphical displays}

Zircon-age data, plotted using the provenance package of Vermeesch et al. (2016), are visualized as kernel density estimates (KDE) with a nominal bandwidth of 40 Ma (Vermeesch, 2012). Statistical techniques used to illustrate our datasets also include the compositional biplot (Gabriel, 1971) and multidimensional scaling (MDS; Vermeesch, 2013; Vermeesch and Garzanti, 2015).

The biplot, drawn using CoDaPack software by Comas-Cufí and Thió-Henestrosa (2011), allows discrimination among multivariate observations (points) while shedding light on the mutual relationships among variables (rays). The length of each ray is proportional to the variance of the corresponding variable in the dataset. If the angle between two rays is close to $0^{\circ}, 90^{\circ}$ or $180^{\circ}$, then the corresponding variables are directly correlated, uncorrelated, or inversely correlated, respectively.

MDS produces a map of points in which the distance among samples is approximately proportional to the Kolmogorov-Smirnov dissimilarity of their compositional or chronological signatures. Closest and second-closest neighbours are linked by solid and dashed lines, respectively, and the goodness of fit is evaluated using the "stress" value of the configuration $(0.2=$ poor; $0.1=$ fair; $0.05=$ good; Kruskal, 1964; table 1 in Vermeesch, 2013; 2018).

\section{Compositional fingerprints of Thal Desert sand}

\subsection{Petrography and heavy minerals}

Three Thal dune samples are litho-feldspatho-quartzose sands and one is quartzo-feldspatho-lithic (average composition Q37 F34 L29; Fig. 3A). Quartz is mostly monocrystalline. K-feldspar and plagioclase occur in subequal amounts. The rock-fragment population includes metasedimentary (paragneiss, schist, slate, calcschist, phyllite, metasandstone), metabasite (prasinite, chloritoschist, 
amphibolite), carbonate (limestone, dolostone), other sedimentary (shale, siltstone, minor chert), granitoid, felsic to mafic volcanic and metavolcanic, and minor ultramafic (serpentineschist, cellular serpentinite) grains (MI 209-290, MI* 273-317). A few muscovite and biotite flakes are present. The very rich tHM suite is dominated by mainly blue-green amphiboles associated with epidote, garnet, green to colourless clinopyroxene, and hypersthene. Titanite, staurolite, kyanite, zircon, tourmaline, rutile, sillimanite, olivine, and chloritoid also occur $($ ZTR $\leq 4)$. Detrital amphiboles include mainly hornblende, subordinate pargasite, actinolite, hastingsite, and minor tschermakite. Detrital garnet is mostly almandine with minor grossular, pyrope, spessartine, and andradite (mostly Bi grains with minor $\mathrm{Ci}, \mathrm{Bii}, \mathrm{A}$, and a few $\mathrm{D}$ grains according to the classification of Mange and Morton, 2007). Epidote-group minerals are mainly clinozoisite and epidote. Detrital pyroxene is mainly diopside with common orthopyroxene and minor augite (Liang et al., 2019).

\subsection{Detrital-zircon geochronology}

The three Thal samples analysed yielded 103 concordant ages overall, including early Miocene (22 Ma; n=3), Eocene (38-53 Ma; n=15), latest Cretaceous/Paleocene (61-84 Ma; n=19), midCretaceous (98-110 Ma; n=10), Orosirian (1.82-1.87 Ga; n=15), and earliest Paleoproterozoic clusters (2.32-2.39 Ga; $n=4)$. Other ages are spread in the Mesozoic $(n=6)$, Paleozoic $(n=6)$, Neoproterozoic $(n=13)$, late Mesoproterozoic $(n=4)$, Paleoproterozoic $(n=4)$, and earliest Paleoproterozoic to late Neoarchean $(n=4)$.

\subsection{Sand geochemistry}

Despite their homogenous provenance, local selective-entrainment effects account for a difference in heavy-mineral concentration by a factor of two in our Thal Desert sand samples. This corresponds to a difference by factors of between 2.5 and 5 of elements preferentially hosted in the densest rock-forming minerals such as opaque Fe-Ti-Cr oxides, monazite, zircon, and to a lesser extent rutile and garnet (i.e., Fe, Ti, Mn, Y, REE, Th, U, Zr, Hf, V, Nb, Ta and Cr). The europium anomaly $\mathrm{Eu} / \mathrm{Eu}^{*}$ varies from 0.74 in the less heavy-mineral rich sample S1474 (Zr $106 \mathrm{ppm}$ ) to 0.46 
299 in the sample richest in heavy minerals $\mathrm{S} 1470$ (Zr $524 \mathrm{ppm}$ ) and is 0.62-0.64 in the other two

samples S1462 and S1463 (Zr 195-213 ppm). The composition of Thal Desert sand compares remarkably well with the Upper Continental Crust standard (UCC; Taylor and McLennan, 1995; Rudnick and Gao, 2003), but with twice as much Th and $\mathrm{Cr}, \sim 50 \%$ more $\mathrm{Ca}, \mathrm{Y}, \mathrm{REE}$, and $\mathrm{Zr}$, and $\sim 50 \%$ less $\mathrm{K}, \mathrm{Rb}$, and $\mathrm{Ba}$, differences all largely accounted for by the strong local concentration of densest minerals by selective-entrainment effects.

\subsection{Nd isotopes}

Neodymium isotope ratios range widely in the studied Thal Desert sand samples. All four samples are fine sands, but coarser samples characterized by higher heavy-mineral concentration and more volcanic, metavolcanic, and metabasite rock fragments have less negative $\varepsilon_{\mathrm{Nd}}(2.0-2.2 \phi$; tHMC 18$19 ; \varepsilon_{\mathrm{Nd}}-3.5$ and -8.7$)$ than finer-grained samples (2.3-2.7 $\phi ;$ tHMC 10-15; $\varepsilon_{\mathrm{Nd}}-10.9$ and -13.2$)$. Because their bulk-sediment mineralogy is homogeneous overall, indicating notably constant provenance, such a marked variability is dominantly controlled by local factors including grain size and concentration of densest minerals by selective entrainment of less dense grains by wind deflation.

\section{Compositional fingerprints of sand sources}

All geological domains drained by the Upper Indus, including the Ladakh and Kohistan arcs, the Karakorum and Hindukush Ranges, the Himalayan belt, and the Nanga Parbat massif are detrital sources of Thal Desert dunes (Fig. 4). The mineralogical signatures of modern sand carried by tributaries draining each geological domain, summarized here below, are illustrated in detail in Garzanti et al. (2005) and Liang et al. (2019).

\subsection{Petrography and heavy minerals}


Indus tributaries draining the Ladakh arc carry quartzo-feldspathic to feldspar-rich feldspathoquartzose plutoniclastic sand with a rich to very rich tHM suite dominated by amphibole (mostly hornblende), with minor epidote, titanite, apatite, and clinopyroxene (mainly diopside). Hypersthene or allanite are found locally.

River sand from the Kohistan arc ranges in composition from feldspatho-quartzo-lithic to lithoquartzo-feldspathic metamorphiclastic with common prasinite and epidote-amphibolite grains and a very rich to extremely rich tHM suite dominated by amphibole (mainly hornblende or pargasite associated with actinolite or hastingsite and rare tschermakite). Epidote-group minerals (mostly clinozoisite) and pyroxene (diopside, pigeonite, augite, and hypersthene) are common, whereas mostly Ca-rich or Mg-rich garnet is rare.

Indus tributaries draining the Karakorum carry sand ranging in composition from quartzofeldspatho-lithic sedimentaclastic (North Karakorum) to quartzo-feldspathic plutoniclastic (Central Karakorum) or litho-feldspatho-quartzose metamorphiclastic with marble grains (South Karakorum). Mainly moderately rich tHM suites include mostly amphibole (mainly hornblende with pargasite, hastingstite, or actinolite), epidote-group minerals (epidote, clinozoisite, and allanite), mostly Bi-type garnet, titanite, mostly diopsidic clinopyroxene, and minor kyanite, staurolite and sillimanite. A similar composition characterizes feldspatho-quartzo-lithic sedimentaclastic sand of the Kabul River upstream of the Swat confluence.

Detritus from the Greater Himalaya, contributed by the Zanskar River and by minor rivers in northern Pakistan, is litho-feldspatho-quartzose metamorphiclastic with a moderately rich tHM suite including amphibole (pargasite and hornblende with minor hastingsite), mostly Bi-type garnet, fibrolitic sillimanite, kyanite, epidote-group minerals (epidote, clinozoisite, minor allanite), and pyroxene (diopside, augite, and locally hypersthene).

Sand supplied by tributaries draining the Nanga Parbat massif is mainly feldspar-rich feldspathoquartzose with an up to very rich tHM suite dominated by amphibole (mainly hornblende with 
352 common tschermakite and minor pargasite). Garnet (mainly $\mathrm{Ci}$ and minor Bii types), pyroxene $\frac{1}{25} 3$ (diopside with rare augite), epidote, clinozoisite, and sillimanite occur.

3 354 5

The Soan River, mostly recycling Cenozoic foreland-basin strata, carries feldspatho-litho-quartzose sedimentaclastic sand with a moderately rich, epidote-dominated tHM suite with garnet, hornblende, and tourmaline.

As far as REE-rich minerals are concerned, allanite is invariably common (2-3 tHM\%) in sand carried by the Hushe, Braldu, Hispar, and Hunza Rivers draining the Karakorum Range. Karakorum-derived sand contains two to five times more allanite than sand shed by the Greater Himalaya and Nanga Parbat, and one order of magnitude more allanite than sand shed by the Ladakh and Kohistan arcs. Monazite is rarer and was detected in sand derived from the Karakorum and in Zanskar sand.

\subsection{Detrital-zircon geochronology}

\subsubsection{Ladakh and Kohistan arcs}

Modern river sand derived from the Transhimalayan arcs yielded simple zircon-age spectra (Fig. 5), reflecting peaks of magmatic activity in the Ladakh (50-70 Ma, Weinberg and Dunlap, 2000; 58-60 Ma, Singh et al., 2007; 50-67 Ma, Ravikant et al., 2009; 47-58 Ma, St-Onge et al., 2010) and Kohistan arc (82-99 Ma, Schaltegger et al., 2002; 42-85 Ma, Jagoutz et al., 2009).

Sand of the Domkar stream draining the Ladakh arc shows a dominant Eocene-Paleocene peak (49$65 \mathrm{Ma} ; \mathrm{n}=34)$ with a younger age at $46 \mathrm{Ma}$ and a Late Cretaceous cluster (78-87 Ma; n=7). Kandia and Swat sands derived from the Kohistan arc display a Late Cretaceous peak (73-95 Ma; $\mathrm{n}=54$ ) with two younger ages at $56 \mathrm{Ma}$ and $69 \mathrm{Ma}$ and three older ages at $716 \mathrm{Ma}, 1086 \mathrm{Ma}$, and $2545 \mathrm{Ma}$. A younger spectrum, very similar to Domkar sand, was obtained by Zhuang et al. (2018) from Dir River sand, which displays a prominent Eocene-Paleocene peak (43-65 Ma; n=76), several Cretaceous aged grains (76-118 Ma; $n=14)$, and a few older grains (196-821 Ma; $n=4)$.

\subsubsection{Karakorum Range}


The four samples of Karakorum river sand yielded 576 concordant ages overall (Fig. 5), including prominent peaks in the early Miocene/latest Oligocene (16-26 Ma; n=19), late Eocene (35-43 Ma; $\mathrm{n}=51$ ), Paleocene (57-66 Ma; $n=10)$, and mid-Cretaceous (99-130 Ma; $n=184$ ), with sparse ages in the Rupelian (31 Ma), early Eocene (48 Ma), Campanian (73 Ma and $76 \mathrm{Ma}$ ), and Turonian (91-92 Ma; $n=4)$. Older ages are irregularly spread between the earliest Cretaceous and the Ordovician (134-484 Ma; $\mathrm{n}=47$ ), form a broad cluster ranging between the Cambrian and the latest Mesoproterozoic (490-1026 Ma; n=201), are again sparsely spread through the Mesoproterozoic and Paleoproterozoic (1050-2448 Ma; n=34), and form a cluster straddling the Proterozoic/Archean boundary (2468-2535 Ma; n=15) with a few older Archean grains (2553-3568 Ma; n=7). Most ages from our Upper Hunza River sample combined with that from the same site analysed by Zhuang et al. (2018) outline two dominant young clusters at 48-74 Ma (n=51) and 101-122 Ma (n=81) with other sparse ages at $44 \mathrm{Ma}, 82-93 \mathrm{Ma}(\mathrm{n}=4), 126-130 \mathrm{Ma}(\mathrm{n}=3)$, and $239 \mathrm{Ma}$. All older ages (377$893 \mathrm{Ma} ; \mathrm{n}=7$ ) are from our sample.

Zircon ages in Karakorum-derived sand correspond closely with the ages of igneous and metamorphic rocks exposed in the range. The early Miocene peak found in zircons from Hushe (19$26 \mathrm{Ma} ; \mathrm{n}=9 / 55)$ and Braldu (16-25 Ma; $\mathrm{n}=10 / 124)$ sands reflects the age of high-grade metamporphism, crustal melting and emplacement of the Baltoro granite (21-26 Ma; Schärer, et al., 1990; 13-26 Ma, Searle et al., 2010; 15-26 Ma, Mahar et al., 2014). The Eocene peak found in Hispar sand (35-42 Ma; $n=48 / 359)$ reflects the age of upper-amphibolite-facies metamorphism in the South Karakorum belt (44-64 Ma, Fraser et al., 2001; 37-55 Ma, Rolland et al., 2001). The Lower Cretaceous peak is prominent in all samples (100-125 Ma; $n=120 / 359$ in Hispar sand, $\mathrm{n}=29 / 124$ in Braldu sand, and $\mathrm{n}=15 / 55$ in Hushe sand) and reflects the emplacement age of the central Karakorum batholith (95-110 Ma, Debon et al., 1987; 95-115 Ma, Crawford and Searle, 1992). Whereas earliest Cretaceous to Silurian zircons are few and possibly recycled from sedimentary and low-grade metasedimentary rocks, ages between the Ordovician and the latest Mesoproterozoic are common in all samples, and reflect the Pan-African orogenic event widely 
408

4) 9

3

410

5

491

412

4913

1994

11

得

14

1456

16

47
18

19

2018

21

24 9

detected in the Himalayas (Garzanti et al., 1986; DeCelles et al., 2000; Miller et al., 2001; Gehrels et al., 2003). Older zircons, mostly represented in Hispar and Braldu sands with ages clustering around $2.5 \mathrm{Ga}$, may be largely recycled from sedimentary and metasedimentary units.

\subsubsection{Hindukush Range and Kabul River}

In a sand sample analysed by Zhuang et al. (2018) from the Chitral-Kunar River, which drains both Hindukush and Karakorum Ranges, half of the zircon ages are spread between the Cambrian and the Tonian (486-976 Ma; $\mathrm{n}=61 / 126)$, whereas minor clusters are documented at $62-70 \mathrm{Ma}(\mathrm{n}=8)$, 102-114 Ma (n=16), 1851-1891 Ma (n=6), and 2467-2515 Ma (n=4).

The zircon age-spectrum obtained by Zhuang et al. (2018) on a sand sample from the Kabul River downstream is notably different, with a younger peak at 31-38 Ma $(\mathrm{n}=12)$, a Cretaceous cluster at 75-113 Ma (n=39), a small peak at 191-204 Ma $(n=10)$ - a Cimmerian age characteristic of Hindukush igneous and metamorphic rocks (Hildebrand et al., 2001) -, a broad Cambrian-Tonian spread (495-986 Ma; n=28), and a few Orosirian (1841-1847 Ma; n=3) and older ages (2074-2592 Ma; $n=7)$. Ages were recorded also at 46-71 Ma (n=3), 123-179 Ma (n=7), 211-482 Ma (n=7), and $1011-1419 \mathrm{Ma}(\mathrm{n}=4)$.

\subsubsection{Nanga Parbat}

The Astor River sand derived from the Nanga Parbat massif yielded a unimodal earliest StatherianOrosirian peak at $1787-1941 \mathrm{Ma}(\mathrm{n}=98)$ consistent with the age of the gneissic basement $(\sim 1850$ Ma; Zeitler et al., 1993; Whittington et al., 2000; Schneider et al., 2001). This major episode of crustal growth is widely recognized in the Lesser Himalaya (e.g., Miller et al., 2000; Singh et al., 2009; Gehrels et al., 2011; “Ulleri-Wangtu” event of Prasad et al., 2011). Older Paleoproterozoic ages (1964-2494 Ma; n=14) and one latest Carboniferous age also occur (Fig. 5). No grain younger than $47 \mathrm{Ma}$ was found, and the few early Eocene to Late Cretaceous zircons (47-88 Ma; n=7) may be derived from the Ladakh arc drained in the upper course.

\subsubsection{Greater Himalaya}


Nandihar River sand derived from the Greater Himalaya in Pakistan yielded mainly early-middle Neoproterozoic ages (740-989 Ma; n=20), with sparse Carboniferous to Ediacaran ages (345-547 $\mathrm{Ma} ; \mathrm{n}=11)$ and a few younger (105 Ma and $216 \mathrm{Ma}$ ) and older grains (1700 Ma, $1803 \mathrm{Ma}$, and 2400 Ma) (Fig. 5). A similar spectrum was obtained by Jonell et al. (2017a) from Zanskar River sand, with better defined Cryogenian-Tonian (751-856 Ma; $\mathrm{n}=44)$ and Carboniferous-Ordovician clusters (337-476 Ma; n=27), and sparse younger (58 Ma, $246 \mathrm{Ma}$, and $301 \mathrm{Ma}$ ) and older ages (1040-3117 $\mathrm{Ma} ; \mathrm{n}=17)$

\subsection{Sand geochemistry}

The provenance-discrimination power of bulk-sediment geochemistry is limited, because the same chemical elements are hosted in different minerals found in a wide range of rocks and because element concentrations are severely affected by grain-size and hydraulic-sorting effects (Garzanti, 2016). Nevertheless, some remarkable differences are noted among sands derived from different geological domains surrounding the western Himalayan syntaxis (Fig. 6A).

Sand derived from the Kohistan arc is enriched 1.5-2 times in $\mathrm{Fe}, \mathrm{Mg}, \mathrm{Ca}, \mathrm{Sc}, \mathrm{Ti}, \mathrm{V}$ and $\mathrm{Cr}$ relatively to the UCC standard, and depleted by $\sim 50 \%$ or more in $\mathrm{K}, \mathrm{Rb}, \mathrm{Ba}, \mathrm{LREE}, \mathrm{Th}, \mathrm{U}, \mathrm{Zr}, \mathrm{Hf}$, $\mathrm{Nb}$, Ta and Sn, reflecting the mainly intermediate to mafic character of calc-alkaline magmatic source-rocks. Domkar sand derived from the Ladakh arc is notably different and much closer to the UCC standard, although depleted by $50 \%$ or more in $\mathrm{Mg}, \mathrm{Nb}, \mathrm{Ta}, \mathrm{Cr}$ and $\mathrm{Co}$, which reflects the more felsic character of the largely granodioritic calc-alkaline source rocks.

Hispar River sand derived from the Central and South Karakorum is enriched by factors of 2-3 relative to the UCC standard in REE, U, Zr and Hf, and by factors of 5-10 in Th, W and As. This may be ascribed to selective entrainment of less dense detrital components in the river channel and consequent concentration of densest minerals probably including monazite and scheelite. Elements most depleted relative to the UCC are $\mathrm{Mg}, \mathrm{V}$, Co and Ni. 
465 Himalayan-derived sand displays overall homogeneous character. Most elements - excepting Si,

$\frac{1}{466}$ 3 467 5 6
468 8 469 10

170 13 147 1 15

162 18 $149 / 3$ 20

274 23 245 25

246 27
287 $249 / 8$ 3099 32 $3+80$ 34 3581

Ca, LREE and Th - are slightly depleted relatively to the UCC standard, which is typical of sand including detritus recycled from sedimentary and metasedimentary rocks. Large differences in Ca and to a lesser extent $\mathrm{Sr}$ reflect varying amounts of carbonate detritus, which is particularly abundant in sand of the Zanskar River cutting across the Tethys Himalaya zone (Blöthe et al., 2014; Jonell et al., 2017a). Zanskar and Astor sands are the closest to UCC composition: Zanskar sand is markedly depleted in V, Cr, Co and $\mathrm{Ni}$, and Astor sand slight enriched in $\mathrm{Rb}$ and $\mathrm{Th}$ and markedly depleted in $\mathrm{Nb}$, Ta and Ni. Soan sand is more depleted (by $\sim 50 \%$ ) in $\mathrm{Na}$ and other mobile alkalic and alkaline-earth metals excepting $\mathrm{Ca}$ and $\mathrm{Sr}$, suggesting weathering inherited from recycling of Cenozoic Himalayan molasse exposed within and around the Potwar Plateau (Garzanti and Resentini, 2016).

\subsection{Nd isotopes}

The ${ }^{143} \mathrm{Nd} /{ }^{144} \mathrm{Nd}$ isotopic ratio provides a useful means to discriminate among different source-rock domains in the Himalayan-Karakorum orogen (e.g., Clift et al., 2002; Chirouze et al., 2015; Zhuang et al., 2015) (Appendix Tables A7 and A8). Juvenile values characterize the Ladakh and Kohistan $\operatorname{arcs}\left(\varepsilon_{\mathrm{Nd}}\right.$ mostly from 0 to +8 ; Petterson et al., 1993; Khan et al., 1997b; Rolland et al., 2002; Jagoutz et al., 2019), whereas the most radiogenic values identify the gneissic basement of the Nanga Parbat massif ( $\varepsilon_{\mathrm{Nd}}$ from -18 to -30; Whittington et al., 1999; Argles et al., 2003). Values are very negative also in Lesser Himalayan rocks $\left(\varepsilon_{\mathrm{Nd}}\right.$ mainly from -19 to -26$)$, but less negative for the Tethyan and Greater Himalaya ( $\varepsilon_{\mathrm{Nd}}$ mainly from -13 to -20; Parrish and Hodges, 1996; Whittington et al., 1999; Ahmad et al., 2000). Values intermediate between the Himalayan belt and Transhimalayan arcs characterize the Karakorum $\left(\varepsilon_{\mathrm{Nd}}\right.$ mainly from -6 to -12 ; Schärer et al., 1990; Mahéo et al., 2009). 


\section{Compositional fingerprints of Indus sand from the mountains to the deep sea}

\subsection{Petrography and heavy minerals}

The modern Upper Indus River carries feldspatho-litho-quartzose sand to the foreland basin, including a variety of sedimentary and metamorphic rock fragments, and a rich hornblendedominated tHM suite with epidote, garnet, and minor clinopyroxene, hypersthene, staurolite, titanite, kyanite, and sillimanite (Fig. 3B). In the mid-Miocene, the Burdigalian-Langhian (18-14 Ma) Kamlial Formation, exposed in the Potwar Plateau and inferred to have been largely deposited by a paleo-Indus River, contains feldspatho-quartzo-lithic sandstones including sedimentary as well as volcanic, metavolcanic, and metabasite rock fragments (Najman et al., 2003). This may represent the time when a drainage system similar to the present one was first established. The existence and compositional fingerprints of a paleo-Indus at older times remain loosely constrained (Clift et al., 2000; Roddaz et al., 2011; Zhuang et al., 2015).

Himalayan tributaries in the Punjab region carry feldspatho-litho-quartzose sand with varied sedimentary and metamorphic rock fragments and mainly moderately rich epidote-amphibolegarnet tHM suites including dravitic tourmaline, kyanite, fibrolitic sillimanite, and staurolite (Fig. 3C). Right-bank tributaries draining the sedimentary succession of the Sulaiman-Kirthar Ranges as well as Indian basement rocks of the Spinghar Crystalline (Badhsah et al., 2000) and the Waziristan, Zhob and Muslimbagh ophiolites (Gnos et al., 1997) - carry feldspatho-quartzo-lithic sedimentaclastic to lithic carbonaticlastic sand yielding very poor to moderately rich tHM suites with epidote, amphibole, clinopyroxene, and garnet. Minor ophiolitic detritus includes serpentinite grains, enstatite, olivine, and Cr-spinel.

The Lower Indus River carries feldspatho-litho-quartzose sand with mostly sedimentary and metamorphic rock fragments, and a rich amphibole-epidote-garnet tHM suite with minor clinopyroxene, titanite, tourmaline, kyanite, staurolite, hypersthene, and sillimanite (Fig. 3D). LGM to Holocene Delta sand has a very similar composition (Clift et al., 2010), with differences mostly 
518 accounted for by hydraulic-sorting effects (more micas, less heavy minerals, and especially less

high-density garnet; Fig. 3E).

Plio-Quaternary Indus Fan turbidites reported from ODP Sites 221 and 222 are more feldspathic (Q49 F31 L20; Suczek and Ingersoll, 1985) than modern Lower Indus River (Q48 F21 L31; Garzanti et al., 2005) and LGM to Holocene Delta sands (Q49 F26 L25; Clift et al., 2010). Recent data from upper Miocene to lower Pleistocene Indus Fan turbidites (Q52 F24 L25; Garzanti et al., 2020), however, indicate that their main composition is quite similar to that of the modern Lower Indus River and LGM to Holocene Delta sands (Fig. 3F), only with more abundant micas in finergrained overbank deposits (Andò et al., 2019).

\subsection{Detrital-zircon geochronology}

Zircon ages from two Upper Indus samples collected between the Kabul confluence and the Salt Range front, combined with data from one sample analysed by Zhuang et al. (2018), cluster mainly between 33 and $124 \mathrm{Ma}(\mathrm{n}=248)$. The youngest cluster occurs at 17-21 Ma (n=5) with another young age at $30 \mathrm{Ma}$ and older ages spread in the Early Cretaceous to Jurassic (127-170 Ma; n=14), Triassic to Permian (205-290 Ma; n=16), and Carboniferous to Ordovician (302-482 Ma; n=17). Zircon grains yielded common Cambrian to Neoproterozoic (485-1000 Ma; n=139) and earliest Statherian-Orosirian ages (1788-1948; n=39), and fewer Mesoproterozoic to late Statherian (1008$1669 \mathrm{Ma} ; \mathrm{n}=24)$ and earliest Orosirian to late Siderian ages (2018-2441 Ma; n=20). The oldest cluster occurs at 2449-2491 Ma (n=9) and several Archean ages were also obtained (2520-3508; $\mathrm{n}=11$ ). Such a composite age spectrum reflects the many distinct geological events that affected the diverse source-rock domains. Age spectra do not change significantly downstream of the confluence with the Soan River, a minor tributary largely recycling Himalayan molasse exposed within and around the Potwar Plateau (Critelli and Garzanti, 1994; Critelli and Ingersoll, 1994).

Sand carried by the Himalayan tributaries of the Punjab (Jhelum, Chenab, Ravi, Beas, and Sutlej samples combined; data after Alizai et al., 2011) include only a few young grains (1 late Oligocene, 
5457 Lutetian-Ypresian, 13 Mesozoic, 1 Carboniferous) and common mid-early Paleozoic (9 Devonian,

13 Silurian, 48 Ordovician, 25 Cambrian) and Neoproterozoic zircons (18 Ediacaran, 32 Cryogenian, 116 Tonian). Mesoproterozoic zircons are much less common (26 Stenian, 7 Ectasian,

9 Calymmian) than Paleoproterozoic zircons (28 Statherian, 110 Orosirian, 22 Rhyacian, 14 Siderian), and 15 Neoarchean, 4 Mesoarchean, and 3 Paleoarchean grains also occur (Appendix Table A9).

Sands in the Lower Indus River, Delta, and Fan display complex zircon-age distributions that reflect all components present in the huge catchment. The age spectrum obtained by combining data on eight modern fluvial and LGM to Holocene deltaic sands (n=766; Clift et al., 2004, 2008, 2010) reveals a marked change in age proportions relative to modern Upper Indus sand. The percentage of Eocene-Cretaceous ages is notably lower, whereas a few more Miocene-Oligocene ages and many more Silurian-Ordovician, Tonian-Stenian, and mid-Paleoproterozoic ages occur. The age spectrum obtained by combining data on five Plio-Quaternary Indus Fan sands ( $\mathrm{n}=624$; Clift et al., 2019) is quite similar, with an even lower percentage of Eocene-Cretaceous ages (Appendix Table A9).

Sand in the Indus Delta and Fan contains zircons as young as 11.3-11.7 Ma (Clift et al., 2010, 2019), which are notably younger than the youngest zircon grain found so far in the Upper Indus catchment (i.e., 15.9 Ma in Braldu sand). Zircon grains even as young as 4.4 Ma have been detected in the Indus Canyon ( $\mathrm{Li}$ et al., 2019). In this regard, it is noteworthy that such very young grains are found only in silt samples with modal grain size $\leq 40 \mu \mathrm{m}$, whereas the youngest zircon in the only sand sample analysed so far is dated as 14.2 Ma. Because such young ages were never obtained from the core of sand-sized zircon grains, it is likely that they correspond to small fragments chipped off the rim of zircon grains with an older core. In the same way, the notably greater abundance of relatively young lower Mesozoic to upper Paleozoic ages in Indus Canyon samples might reflect the greater frequency of zircon rims recording thermal events that followed the PanAfrican orogeny. The other peculiar features of Indus Canyon zircons (spectrum of 988 ages combined from ten medium silts to fine sands deposited in the last $50 \mathrm{ka}$; Li et al., 2019) are the 
much smaller population of Orosirian aged grains and the disappearance of the minor cluster around $2.5 \mathrm{Ga}$, which also may be explained by a greater frequency of analysed small grains, originally representing younger rims surrounding older crystal cores.

\subsection{Sand geochemistry}

Upper Indus sand is similar to the UCC standard, apart from a moderate enrichment in elements preferentially concentrated in densest minerals such as zircon and monazite ( $\mathrm{Zr} 254-323$ ppm, $\mathrm{Eu} / \mathrm{Eu}^{*}$ 0.51-0.61) and a depletion in $\mathrm{Na}, \mathrm{K}, \mathrm{Rb}$ and Ba preferentially hosted in alkali feldspars.

In sand carried by the Himalayan tributaries of the Punjab, most elements - except $\mathrm{Si}$, and $\mathrm{Ca}$ in Jhelum and Sutlej sands - are depleted relatively to the UCC standard (Fig. 6B), which is typical of sand including detritus recycled from sedimentary and metasedimentary rocks. Elements preferentially hosted in densest minerals are slightly enriched in the Sutlej (Zr 281 ppm, Eu/Eu* 0.43) and Jhelum samples ( $\mathrm{Zr} 230 \mathrm{ppm}, \mathrm{Eu} / \mathrm{Eu}^{*}$ 0.60) and slightly depleted in the Chenab sample (Zr $123 \mathrm{ppm}, \mathrm{Eu} / \mathrm{Eu}^{*}$ 0.72) owing to local differences in heavy-mineral concentration possibly caused by moderate selective-entrainment processes.

Relatively to Upper Indus sand, Lower Indus sand is depleted in most elements except $\mathrm{Si}, \mathrm{Ca}$, and P. This reflects major additional contribution from metamorphic and siliciclastic rocks richer in quartz. Relatively to Lower Indus River sand, LGM to Holocene deltaic sediments are instead enriched in most elements but $\mathrm{Si}, \mathrm{Y}, \mathrm{REE}, \mathrm{Zr}$ and $\mathrm{Hf}$, and especially in $\mathrm{Al}, \mathrm{Fe}, \mathrm{Mg}, \mathrm{K}, \mathrm{Rb}, \mathrm{V}, \mathrm{Co}$, $\mathrm{Ni}, \mathrm{Cu}$, and loss on ignition (Fig. 6B), which is chiefly ascribed to their finer average grain size and higher phyllosilicate content.

\subsection{Nd isotopes}

In modern Indus sand, $\varepsilon_{\mathrm{Nd}}$ values have been shown to decrease progressively from -8.4 upstream of the western syntaxis to -10.8 upstream of Tarbela Dam, and to -15.0 upstream of the delta, documenting a progressive dilution of less radiogenic and unradiogenic sediment generated in the 
Karakorum and Transhimalayan arcs by more radiogenic sediment derived from the Nanga Parbat massif and Himalayan belt (Clift et al., 2002). In LGM to Holocene sand of the Indus Delta, $\varepsilon_{\mathrm{Nd}}$ varies between -11 and -15 (Clift et al., 2010; Jonell et al., 2018), whereas in turbidites of the Indus Fan $\varepsilon_{\mathrm{Nd}}$ values remained mostly between -8.5 and -11.5 until 5.7 Ma, after which they declined to between -9 and -12 until 3 Ma and finally to between -11 and -14 thereafter (Clift et al., 2019).

\section{Provenance of Thal Desert sand}

Based on the detailed compositional information on end-member sources illustrated above, the relative contributions from each geological domain to eolian sand of the Thal Desert can be calculated by forward mixing models according to the method illustrated in Garzanti et al. (2012) and Resentini et al. (2017). These calculations are non-unique and uncertain, being affected by various sources of error including the imprecise assessment of end-member sources owing to a limited number of samples and locally significant hydraulic-sorting effects. The calculations also depend on a variety of premises that are never strictly verified, including the assumption that selective mechanical or chemical breakdown of detrital components is negligible. The accuracy of the results thus needs to be increased by performing several independent tests according to different criteria for each dataset (i.e., petrography and heavy minerals, geochemistry, zircon age spectra, and $\mathrm{Nd}$ isotopes), keeping in mind that each estimate thus obtained refers only to the investigated set of components and grain-size range (i.e., sand, transparent heavy minerals, zircon, and Nd-rich phases; Garzanti, 2016). Extrapolating such diverse and not necessarily identical or even similar provenance budgets to the entire sediment flux, which is a necessary step to calculate sediment yields and erosion rates in different parts of the catchment, is a challenging endeavour fraught with uncertainties, which requires careful consideration of mineral fertilities in each source-rock domain (Malusà et al., 2016).

\subsection{Petrography and heavy minerals}


627 The provenance budget based on integrated petrographic and heavy-mineral data from the Upper

Indus catchment and obtained after numerous sets of independent calculations indicated that bedload sand upstream of Tarbela Dam is predominantly derived from the Karakorum Range

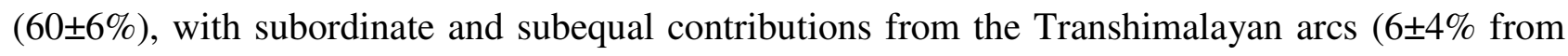
the Ladakh Arc and South Tibet; $14 \pm 4 \%$ from the Kohistan Arc) and Himalayan units (Nanga

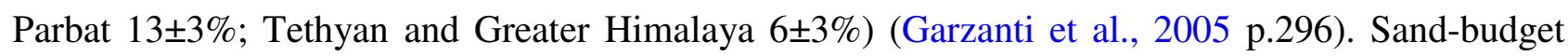
estimates are far less precise downstream of Tarbela Dam, because sediment discharge has been profoundly modified by human activities. Because of effective sediment sequestration in the Tarbela reservoir, the composition of Indus sand downstream of the Kabul confluence is very close to Kabul sand, and modern sand at the Salt Range front was estimated to be derived in significant

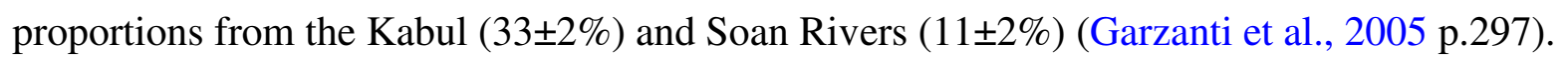

Compared to modern Upper Indus sand, Thal Desert dunes are notably poorer in quartz and sedimentary to low-rank metasedimentary rock fragments, and richer in feldspars, volcanic, metavolcanic and metabasite rock fragments, heavy minerals and especially hypersthene, documenting a significantly greater contribution from the Kohistan arc (Fig. 4). Although precise estimates are hard to obtain because of strong local selective-entrainment effects caused by wind deflation and partial overlap among end members, detrital modes of Thal dune sand can be satisfactorily reproduced as a 36:64 mixture of Kohistan and Upper Indus sand. Thal dune sand is thus assessed to be derived from the Transhimalayan arcs (40-45\%, predominantly from the Kohistan arc), the Karakorum-Hindukush Ranges (40-50\%, at least a third of which via the Kabul River according to suspended-load data of Rehman et al., 1997), the Nanga Parbat massif (<10\%), and the Himalayan belt $(<10 \%$, including detritus recycled by the Soan River).

Further clues are obtained from electron-microprobe mineral-chemical data, which showed that the Kohistan arc played the principal role as a source of the most common groups of transparent heavy minerals, especially pyroxene and epidote (Fig. 7). The South Karakorum gneiss domes undergoing fast exhumation, and to a lesser extent the Nanga Parbat massif, represent important additional 
653

$\frac{1}{624}$ 3 695 5 6,56 687 658 10 12 1650 14

$\frac{15}{16} 1$ 17 1562 19

2063 22 2064 24 2555 26 31

sources of amphibole, garnet and zircon, whereas the contribution from other Himalayan domains is major only for Lower Indus sand downstream of the Thal Desert (Lee et al., 2003; Alizai et al., 2016).

\subsection{Detrital-zircon geochronology}

In the Upper Indus catchment, Miocene grains were found only in sand of the Braldu and Hushe Rivers draining the Baltoro granite. The youngest age population found in Thal Desert (22 Ma; $3 \%$ of total zircons) and Upper Indus sand (17-21 Ma; $1 \%$ of total zircons) are thus most likely derived from the Karakorum. Oligocene to Aptian grains (46\% of total zircons in both Thal Desert and Upper Indus sand) are predominantly derived from the Karakorum Range (peaks at 24-43 Ma and 99-130 Ma) and Transhimalayan arcs (43-96 Ma). Paleozoic and Neoproterozoic grains (18\% and $30 \%$ of total zircons in Thal dunes and Upper Indus sand) are contributed by both Karakorum and Himalayan sources, whereas Orosirian grains (peak at $1.85-1.86 \mathrm{Ga} ; 16 \%$ and $7 \%$ of total zircons in Thal dunes and Upper Indus sand) are chiefly derived from the Nanga Parbat massif (Fig. 5).

A set of simple forward mixing calculations based on age groups defined by different criteria and choosing different bandwidths indicate that zircons in Thal dune sand are largely derived from the Transhimalayan arcs (34-40\%), Karakorum-Hindukush Ranges (28-34\%), Nanga Parbat massif (2021\%), and Himalayan belt (11-12\%) (Fig. 8A). Instead, zircon grains in modern Upper Indus sand are mostly derived from the Karakorum-Hindukush Ranges (60-66\%) and Transhimalayan arcs (1724\%), with minor contributions from the Nanga Parbat massif (9\%) and the Himalayan belt (7-8\%). The percentages of zircon grains supplied via the Kabul River draining both the KarakorumHindukush Ranges and the Kohistan arc cannot be estimated accurately, but is most probably significant (10-20\%), as revealed by the greater percentage of Jurassic/Triassic ages in both Upper Indus and Thal Desert sands than in any studied catchment upstream of Tarbela Dam.

\subsection{Sand geochemistry}


681 The composition of Thal Desert sand compares well with that of modern Upper Indus sand (Fig.

6A), confirming that they share the same provenance with insignificant supply from the Jhelum River or other Himalayan tributaries of the Punjab. Approximate forward mixing calculations based on bulk-sediment geochemistry suggest that $\sim 50 \%$ of the sand in the Thal dune field may be derived from the Karakorum Range, 40\% from the Kohistan arc, and only 10\% from diverse Himalayan sources. This indicates that the Kohistan arc contributed more at those times, and the Himalayan belt less, than at present.

\subsection{Nd isotopes}

The great intersample variability of $\varepsilon_{\mathrm{Nd}}$ values observed in Thal Desert sand - even in samples collected less than $30 \mathrm{~km}$ apart in the middle of the dune field - cannot be explained by differences in provenance. This is thus an exemplary case that highlights the difficulties of decoding the provenance signal carried by $\mathrm{Nd}$ isotopes, which requires full understanding of the detrital components that control the Nd budget as well as of hydraulic-sorting processes (Garçon et al., 2014). Moreover, if detritus is derived from multiple tectonic domains with overlapping signatures, as it is the case in a large river system such as the Indus draining a complex orogenic belt, then the same isotopic ratio can be produced by several different combinations of detrital sources and is therefore unable to provide an unequivocal answer (Garzanti, 2016).

Based on bulk-sand provenance budgets discussed above in subsections 7.1 and 7.3 and on average $\varepsilon_{\mathrm{Nd}}$ values given in Zhuang et al. (2015) for the Karakorum (-9.6), Ladakh-Kohistan arc (+4.9), Greater Himalaya (-14.7) and Nanga Parbat massif (-25; Clift et al., 2002), the expected $\varepsilon_{\mathrm{Nd}}$ in Thal sand would range between -3.5 and -5.5 (versus observed values between -3.5 and -13.2 ), whereas that of Indus sand upstream of Tarbela Dam would be close to -9 (versus an observed value of 10.8; Clift et al., 2002). Observed values more negative than expected - outside the $\pm 1 \varepsilon_{\mathrm{Nd}}$ uncertainty estimated by Jonell et al. (2018) - call for an explanation. 
Studies of sand generated in the Himalayan orogen have shown that $80-90 \%$ of their $\mathrm{Nd}$ is

contained in transparent heavy minerals, mostly in allanite and monazite and subordinately in titanite, apatite, other epidote-group minerals, and amphibole (Garzanti et al., 2010, 2011). The $\mathrm{Nd}$ isotopic signature of orogenic sediment is thus markedly affected by the presence of REE-rich monazite and allanite grains even where their concentration is very low (Garçon et al., 2014; Jonell et al., 2018; Garzanti et al., 2019).

High-resolution heavy-mineral data obtained with semi-automated Raman spectroscopy (Appendix Table A4) indicate that REE-rich allanite is most abundant by far in Karakorum-derived sand, minor in sand from the Greater Himalaya, and rare in sand from the Transhimalayan arcs and Nanga Parbat massif (Liang et al., 2019), whereas monazite was detected only in sand generated in the Karakorum and Greater Himalaya. The average $\varepsilon_{\mathrm{Nd}}$ value carried by monazite grains is therefore predicted to be more negative than that carried by allanite. This is corroborated by semi-automated Raman-point-counting heavy-mineral analysis, which detected significant monazite (0.3 tHM\%) and a little allanite $(0.1 \mathrm{tHM} \%)$ in sample S1462 yielding the most strongly negative $\varepsilon_{\mathrm{Nd}}$ value (13.2), a little monazite ( $0.1 \mathrm{tHM} \%)$ and no allanite in sample S1474 yielding the other strongly negative $\varepsilon_{\mathrm{Nd}}$ value (-10.9), and some allanite (0.1 and $\left.0.6 \mathrm{tHM} \%\right)$ but no monazite in samples S1470 and S1463 yielding the least negative $\varepsilon_{\mathrm{Nd}}$ values (-8.7 and -3.5$)$.

The results of heavy-mineral point-counting cannot be very precise in this regard, because the amount of monazite in our sand samples is exceedingly small. Moreover, Nd-bearing minerals may be present as undetected tiny inclusions in other detrital grains. Nevertheless, because every 100 ppm of monazite hosting $\sim 10^{5} \mathrm{ppm}$ of Nd contributes $\sim 10 \mathrm{ppm}$ of $\mathrm{Nd}$ to the bulk sand, our results suggest that most of the $\mathrm{Nd}$ in sample S1462 (containing $30 \mathrm{ppm}$ of Nd overall) and much of the $\mathrm{Nd}$ in sample S1474 (containing only 19 ppm overall) may well be provided by monazite of Greater Himalayan provenance with an $\varepsilon_{\mathrm{Nd}}$ value of $\sim 15$ (Cottle et al., 2019), thus resulting in unexpectedly low bulk-sand $\varepsilon_{\mathrm{Nd}}$ values of -13.2 and -10.9. A few monazite (or allanite) grains from the Nanga 
1 733 3 4 754 6 735 9 प्रक 6 11 12,37 14 1,538 16

Parbat massif may also be responsible for such a sharp local drop in $\varepsilon_{\mathrm{Nd}}$ values. These observations indicate that REE-rich monazite (or allanite) grains carrying a strongly negative $\varepsilon_{\mathrm{Nd}}$ fingerprint, even in amounts so small that seriously challenge the resolution power of current analytical methods, can produce an unexpectedly strong local decrease in $\varepsilon_{\mathrm{Nd}}$ values. The uncertainties of provenance budgets based on bulk-sand $\mathrm{Nd}$ isotopes are consequently increased.

\section{Provenance of Lower Indus, Indus Delta, and Indus Fan sand}

\subsection{Petrography and heavy minerals}

In the Lower Indus catchment, where the sediment flux has been profoundly modified by man, sediment-budget calculations are affected by large uncertainties. Big dams and link canals, built along both the trunk river and Punjab tributaries since Pakistan's independence in 1947 and especially after the Indus Waters Treaty in 1960, have greatly hampered sediment transit across the Punjab plains. The entire water discharge of the Ravi and Sutlej Rivers has been retained upstream in India except during monsoon floods, triggering sediment reworking and erratic mixing and blurring of provenance signals in Pakistan downstream. All along the eastern edge of the Thal Desert, changes in composition observed in sand of the Jhelum River and downstream of the Jhelum-Chenab confluence reveal fluvial reworking of Thal dune sand, which may locally represent up to more than $20 \%$ of river bedload (Garzanti et al., 2005 p.297). Forward mixing calculations based on the integrated petrographic and mineralogical dataset tentatively indicated a $39 \pm 4 \%$ contribution from the Himalayan tributaries of the Punjab to Lower Indus sand of ( $15 \pm 6 \%$ of which from the Jhelum, $33 \pm 7 \%$ from the Chenab, $4 \pm 4 \%$ from the Ravi, $40 \pm 8 \%$ from the Sutlej, and 9 $\pm 3 \%$ from reworking of Thal dunes; Garzanti et al., 2005 p.297-298).

Provenance budgets thus suggest relative supply from the Upper Indus and Himalayan tributaries of the Punjab in proportion 60:40, with very minor additional detritus from the Sulaiman-Kirthar Ranges in the west. These figures are notably similar to what is observed on the eastern side of 
peninsular India, where sediments in the Bengal Delta and Bengal Fan are assessed to be derived $\geq$ $60 \%$ from the Brahmaputra River draining the eastern Himalayan syntaxis and $\leq 40 \%$ from the Ganga River chiefly draining the Himalayan belt, with very minor additional detritus from the IndoBurman Ranges in the east (Lupker et al., 2013; Borromeo et al., 2019; Garzanti et al., 2019). A remarkable symmetry in the proportion of sediment generated from the Himalayan belt and carried by rivers draining the Himalaya exclusively or dominantly (e.g., Punjab rivers and Ganga) versus rivers sourced in Tibet and cutting across the western and eastern syntaxes (e.g., Indus and Brahmaputra) is thus observed on opposite sides of the India-Asia collision system (figure 5 in Garzanti et al., 2005).

Given the overall similarity in composition (Fig. 9A), sand budgets based on petrographic and heavy-mineral data are not drastically different for the modern Lower Indus, the LGM to Holocene Delta, and the early Pleistocene Indus Fan. However, a subtle compositional shift in detrital modes from Miocene-Pleistocene deep-sea-fan turbidites to Holocene and modern fluvio-deltaic sands points to progressively increasing relative supply from the Himalayan belt (light grey arrow in Fig. 9B), which is consistent with decreasing $\varepsilon_{\mathrm{Nd}}$ values and increasing relative abundance of zircon grains older than 300 Ma observed in Indus Fan turbidites since the latest Miocene (Clift et al., 2019). At even earlier, mid-Miocene times (18-14 Ma), a sudden influx of volcanic detritus to the foreland basin testifies to the onset of rapid exhumation of the Kohistan arc in the western Himalaya syntaxis (Kamlial Formation in Fig. 9A; Najman et al., 2003), which is consistent with increasing $\varepsilon_{\mathrm{Nd}}$ values recorded by Indus Fan turbidites from $17 \mathrm{Ma}$ to $9.5 \mathrm{Ma}$ (Clift et al., 2019).

\subsection{Detrital-zircon geochronology}

Data from Clift et al. $(2004,2008,2019)$ show that zircon grains younger than $125 \mathrm{Ma}$ - which account for $47-49 \%$ of the zircon population in Upper Indus and Thal Desert sands - are still common in LGM to Holocene sand of the Indus Delta (34\%) downstream. Young grains are also found in the Plio-Quaternary Indus Fan (17\%), although they are few in sand carried by Himalayan 
tributaries of the Punjab $(\sim 3 \%)$. This indicates that detrital zircon in the modern Lower Indus River, LGM to Holocene Delta, and Plio-Quaternary Fan is derived from the Upper Indus and Punjab tributaries in roughly similar proportions (Fig. 8B), with notable short-term variations in space and time (Clift et al., 2008, 2019; Li et al., 2019). Despite a zircon-age dataset that has been rapidly expanded in the last decade, estimates of zircon contributions from various parts of the catchment still vary widely. Alizai et al. (2011, their table 7 and figure 12A) estimated that two-thirds of zircon grains in the modern delta are supplied by the Himalayan tributaries of the Punjab (two-thirds of which by the Sutlej River), which is largely explained by the high zircon fertility of Himalayan rocks. Our set of forward mixing calculations, based on age groups defined by diverse criteria, suggest that the Upper Indus may have supplied on average $45-48 \%$ of detrital zircon to the PlioQuaternary Fan and up to 55-67\% of detrital zircon to the LGM-Holocene Delta. Similar, but less robust estimates are obtained from Indus Canyon zircon-age data (Li et al., 2019), which is largely ascribed to the finer grain-size of the analysed zircons and short timescale variability. The different proportions of original cores and rims of zircon grains in samples of markedly different grain size may explain the notable variability observed even at the centennial to millennial time scale, which may be at least partly caused by the variable grain size of the studied samples rather than by provenance changes.

\subsection{Sand geochemistry}

The geochemical composition of modern Lower Indus sand indicates a much higher percentage of Himalayan detritus than in Thal Desert and Upper Indus River sands (Fig. 6B). Forward mixing calculations, affected by the same uncertainties discussed for the petrographic-mineralogical sand budget illustrated in subsection 8.1 above, suggest that the Upper Indus and the Himalayan tributaries of the Punjab provide sand in roughly equal amounts to the Lower Indus and LGM to

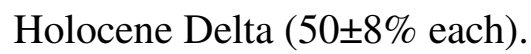

\subsection{Nd isotopes}


814

815

2

816 4

5 8617 7 8918 10 P19 12 1820 14

15 17

$\mathrm{Nd}$ isotopes have long been used to identify sediment sources and to trace erosion patterns in the huge Indus drainage basin. In modern Indus River sand, the sharp decrease in $\varepsilon_{\mathrm{Nd}}$ values across the foreland basin documents the progressive dilution of detritus shed from more juvenile Karakorum and Transhimalayan arc sources by more radiogenic Himalayan detritus supplied by the Punjab tributaries in the lower course (Clift et al., 2002). Values as negative as -15.4 in the modern delta contrast with less negative values measured from Pleistocene Indus Fan sediments cored at ODP Site $720\left(\varepsilon_{\mathrm{Nd}}-12.5\right.$ and -14.0; Clift et al., 2001) and IODP Sites U1456 and U1457 ( $\varepsilon_{\mathrm{Nd}}-9.5$ and 13.0; Clift et al., 2019; Yu et al., 2019). Although this discrepancy may partly result from reduced sediment flux from the Upper Indus after the closure of the Tarbela Dam, Indus Delta sediments do document a progressive increase of detrital supply from the radiogenic Lesser Himalaya since the Last Glacial Maximum (LGM), with relatively reduced contributions from Transhimalayan and Karakorum sources. The $\varepsilon_{\mathrm{Nd}}$ values decreased from -11 to -12 between the LGM and the beginning of the Younger Dryas $(\sim 12.7 \mathrm{ka})$, to reach -15 around $-8.7 \mathrm{ka}$, a change ascribed to enhanced erosion along the southern Himalayan front caused by the increasing intensity of summer monsoon rains (Clift et al., 2008, 2010).

Upper Miocene to Pleistocene Indus Fan sediments recently drilled by IODP Expedition 355 to the Laxmi Basin also show less radiogenic $\varepsilon_{\mathrm{Nd}}$ values than recent sediments in the Indus Delta, with a pronounced decline throughout the Pliocene ascribed to an accelerated exhumation of the Lesser Himalaya and, to a lesser extent, of the Nanga Parbat massif (Clift et al., 2019). Laxmi Basin sediments deposited during the last $600 \mathrm{ka}$ yielded less radiogenic $\varepsilon_{\mathrm{Nd}}$ values mostly between -9.5 and -13.0, which however reflects mixing of sediment supplied not only by the Indus River but also by rivers draining Deccan Trap basalts in Peninsular India (Yu et al., 2019), as independently documented by heavy-mineral data (Garzanti et al., 2020).

\section{Climatic control on latest Quaternary erosion patterns}


841 In provenance studies, each one of the many different possible approaches adds useful

2

complementary information but hardly ever provides a sharp univocal response. Among bulksediment methods, petrographic analysis applies to bedload sand only and geochemistry has limited discrimination power with the notable exception of mafic source rocks. Heavy-mineral suites are strongly affected by hydraulic sorting and selective chemical dissolution during the successive stages of a sedimentary cycle. Age spectra of detrital zircon are strongly distorted by fertility effects and heavily biased in favour of felsic igneous and metaigneous sources; moreover, grains recycled even several times from siliciclastic covers cannot be distinguished from first-cycle grains derived directly from basement rocks. $\mathrm{Nd}$ isotopic ratios suffer from overlap among the fingerprints of diverse source-rock domains, are strongly influenced by grain size and hydraulic-sorting effects, and are highly dependent on rare minerals very rich in REE such as monazite, which can control the Nd budget even if present in amounts so small that can hardly be assessed precisely enough by current techniques.

Nevertheless, the evidence provided by these different methods combined, as illustrated in Sections 4, 5 and 6 and discussed in Sections 7 and 8, indicates robustly enough that the Thal dune field was fed entirely by the paleo-Upper Indus at a time when erosion was focused to the north of the Himalayan belt, and specifically in the Kohistan arc and Karakorum Range. All provenance budgets based on integrated petrographic-mineralogical data, bulk-sediment geochemistry, age spectra of detrital zircon, and $\mathrm{Nd}$ isotope ratio converge to indicate that Thal Desert sand was originally derived $\sim 40 \%$ from erosion of the Kohistan arc, up to $50 \%$ from the Karakorum Range, and only in minor amount from diverse Himalayan sources. Instead, $\sim 60 \%$ of modern Indus sand upstream of Tarbela Dam is assessed to be derived from the Karakorum, the rest being supplied in subequal amounts by the Transhimalayan arcs and the Himalayan belt.

In Thal Desert sand, the low abundance of quartz and high abundance of feldspars and volcanic, metavolcanic and metabasite rock fragments, the very rich tHM suites including common 
866

1 867 3 868 6 869 8 890 10 11 82 13 1842 15

363 88/4

195 2176 22

hypersthene, the common zircon grains of Late Cretaceous to early Paleogene age, and the $\varepsilon_{\mathrm{Nd}}$ values less negative than those of Upper Indus sand and as high as -3.5 are all clear evidence of major contribution from the Kohistan arc. Notably greater detrital supply from juvenile sources lying to the north of the Himalayan belt than in the modern Upper Indus system indicates markedly different conditions of sediment generation at a time when the paleo-Upper Indus delivered to the foreland basin volumes of sand to be subsequently reworked by wind and accumulated in the Thal dune field.

\subsection{Eolian sedimentation in the dry latest Pleistocene}

A precise chronology of the evolution of the Thal Desert has not been established yet, whereas thermoluminescence dating of eolian sediments in the Thar Desert of southern Pakistan has revealed multistep phases of dune accretion through the last $200 \mathrm{ka}$ alternating with precessiondriven interludes of wetter climate (Singhvi et al., 2010). The last major phase of dune growth in the eastern Thar Desert took place under a transitional climate, when SW monsoon winds were being re-established following a peak in aridity during the LGM characterized by a very weak SW monsoon. Sand aggradation in the eastern desert took place between $17 \mathrm{ka}$ and $14 \mathrm{ka}$ and lasted until $9 \mathrm{ka}$, at the onset of the early Holocene wet stage (Dhir et al., 2010; Singhvi et al., 2010). In contrast, the western Thar Desert has been supplied by sediment from the Indus Delta since the onset of the wetter Holocene and expanded further west as the climate dried after the mid-Holocene (East et al., 2015). The recent finding of Mesolithic artefacts dated as the first millennia of the Holocene on top of sand dunes of both Thar and Thal Deserts (Biagi et al., 2019), suggests that a chronology similar to the eastern Thar Desert may be extrapolated to the Thal Desert.

The compositional fingerprints of Thal dunes indicate that detritus was largely generated by erosion in the high Karakorum and Kohistan Ranges in the northern part of the western Himalayan syntaxis (Fig. 9A). During deglaciation following the LGM, sediment fluxes were augmented by incision of moraines and fluvial terraces in the mountains (Clift and Giosan, 2014; Blöthe et al., 2014; Jonell et 
al., 2017b). In this latest Pleistocene period of weak summer monsoonal rains, meltwater fluxes

from shrinking mountain glaciers were insufficient to guarantee a constant full sediment-transport capacity to the paleo-Upper Indus River, fluvial sediments were dumped and extensively reworked by wind in the lowlands, and sand blown by progressively strengthening winds accumulated in dune fields all across the dry foreland basin (Fig. 10A).

In the Indus Delta, a ravinement surface formed at this time of sea-level rise, as documented by a hiatus separating sand deposited during the LGM (radiocarbon ages $28.7 \mathrm{ka}$ and $38.9 \mathrm{ka}$ ) from the overlying sediments deposited since $\sim 15 \mathrm{ka}$ and documenting sustained progradation since $\sim 12 \mathrm{ka}$ (Clift et al., 2008, 2010). Sediments deposited during and immediately after the LGM carry a notably less negative isotopic signature $\left(\varepsilon_{\mathrm{Nd}}-11\right.$ to -12$)$ than more recent deposits, which confirms a greater contribution from juvenile Transhimalayan sources at those times (Fig. 8B). The $\varepsilon_{\mathrm{Nd}}$ values started to decrease with the beginning of the Younger Dryas, a consequence of increasingly focalized erosion along the southern Himalayan front (Clift et al., 2010). Changing climatic conditions since the LGM have certainly contributed to such a prominent shift in erosion patterns and accelerated erosional denudation of the Himalayan belt (Clift et al., 2008, 2019).

\subsection{Changing landscapes in the Holocene}

Global warming and intensification of the South Asian monsoon led to much wetter conditions in the early Holocene, when water and sediment discharge from the Himalayan orogen very markedly increased, fuelled by heavier monsoonal rains. This is documented by notably enhanced freshwater influx peaking around $10.8 \mathrm{ka}$, as recorded by low $\delta^{18} \mathrm{O}$ in foraminifera off the coast of Pakistan (Staubwasser et al., 2002) and by progradation of the Indus Delta even at a time of rapid sea-level rise, fostered by augmented sediment delivery between $13 \mathrm{ka}$ and $9.5 \mathrm{ka}$ (Giosan et al., 2006b). On the opposite side of Peninsular India, the strengthened early Holocene monsoon is held responsible for greatly increased sediment supply to the Bengal Delta between $\sim 11 \mathrm{ka}$ and $7 \mathrm{ka}$ (Goodbred and Kuehl, 2000). This wet period fostered the formation of lakes in the Thar Desert from $\sim 7$ ka to $\sim 5$ 

1
921 3 ${ }_{5}^{4} 2$ 6 923 8

ka (Enzel et al. 1999; Roy et al., 2009). Lakes desiccated at the onset of a new arid phase at $\sim 4 \mathrm{ka}$ (Giosan et al., 2012; Dixit et al., 2014), which was followed by several other wet events of shorter duration and smaller magnitude (Prasad and Enzel, 2006).

The Thal Desert, therefore, testifies to the markedly different landscape that preceded the wet early Holocene, when strongly enhanced water discharge led to incision and reworking of the Thal and Thar dune fields by the Indus and its Punjab tributaries draining the Himalayan front, directly and most strongly hit by the heavy rains brought in by the renewed strength of the South Asian monsoon (Fig. 10B).

\section{Conclusions}

The distinctive petrographic, heavy-mineral, mineral-chemical, U-Pb zircon-age, geochemical, and Nd-isotope fingerprints of Thal Desert sand reveal that this dune field was fed entirely by the paleoUpper Indus at a time when erosion was focused in the Kohistan arc and Karakorum Range to the north of the Himalayan belt. Thermoluminescence chronology and artefacts dated at the first millennia of the Holocene found on top of sand dunes of both Thal and Thar Deserts indicate that these dune fields expanded in semi-dry climate during the latest Pleistocene. In this period, global warming and glacial retreat following the Last Glacial Maximum fostered enhanced detrital supply from the high Kohistan and Karakorum Ranges of the western Himalayan syntaxis. When meltwater fluxes from shrinking mountain glaciers were reduced, at a time of weak monsoonal rains, the sediment-transport capacity of the paleo-Upper Indus River was also reduced. Fluvial sediments were dumped and extensively reworked by wind in the lowlands, and sand accumulated in dune fields across the dry foreland basin. Sand stored in the Thal dune field thus testifies to a major change in Himalayan landscape and erosion patterns that took place at a time of rapid climatic transition from dry periglacial settings during the Last Glacial Maximum to wet conditions in the early Holocene, when markedly enhanced river water and sediment discharge was fuelled by intensified monsoonal rainfall. 


\section{ACKNOWLEDGMENTS}

Heartfelt thanks to Giacomo Ghielmi and Filippo Lazzati, who collected sand samples in the Thal

Desert and around the western Himalayan syntaxis, and to Henry Munack and Jan Blöthe who

1952 11

123 14

1554 16

7755 19 256 21

provided samples from Ladakh. The Braldu and Hushe samples were collected and kindly provided by Mike Searle. Guido Pastore helped with several geochronological analyses. This study was supported financially by Projects MIUR-PRIN 2015EC9PJ5 "The subduction and exhumation of the continental lithosphere: their effects on the structure and evolution of the orogens" and MIUR Dipartimenti di Eccellenza 2018-2022, Department of Earth and Environmental Sciences, University of Milano-Bicocca. We warmly thank ESR Editor Chris Fielding and an anonymous reviewer for their useful comments and constructive advice.

\section{SUPPLEMENTARY MATERIALS}

Supplementary data associated with this article, to be found in the online version at http://dx.doi.__ , include information on sampling sites (Table A1), together with the complete datasets on sand petrography (Table A2), heavy minerals (Table A3), heavy-mineral point-counting by semi-automated Raman spectroscopy (Table A4), percentages of amphibole, garnet, epidote, and pyroxene varieties in each source-rock domain (Table A5), sand geochemistry (Table A6), and $\mathrm{Nd}$ isotopes (Table A7). A compilation of $\mathrm{Nd}$ isotope values from bedrocks and sediments from the Himalayan-Karakorum orogen is shown in Table A8 and original and literature data on zircon-age distributions are summarized in Table A9, whereas the full original detritalzircon geochronology dataset is illustrated in Appendix B. The Google-Earth ${ }^{\mathrm{TM}}$ map of sampling sites Thal Review.kmz is also provided. 


\section{FIGURE CAPTIONS}

Figure 1. The Thal Desert is situated where the Upper Indus reaches the foreland basin to the south of the western Himalayan syntaxis (WHS) and to the west of the Punjab plain. Location of the four studied Thal dune samples is indicated by orange stars. Inset shows area enlarged in the Google Earth $^{\mathrm{TM}}$ image; the white circle indicates the Indus Canyon, and the white star the location of the Laxmi Basin targeted by IODP Expedition 355. Ga and $\mathrm{Br}=$ Ganga and Brahmaputra Rivers.

Figure 2. Geological map of the Indus catchment (mod. after Garzanti et al., 2005) indicating the studied Indus tributaries and sampling sites. Blue stars in the Indus Delta indicate location of the Thatta (T), Jati (J), and Keti Bandar (K) cores.

Figure 3. Sand petrography. Thal Desert sand is enriched in plagioclase, volcanic to metabasite rock fragments, and pyroxenes (A; S1462) relative to Upper Indus sand (B; S1447). Sand supplied by Punjab tributaries downstream of the Thal Desert includes abundant metasedimentary detritus from the Himalaya (C; S1424). Sands in the Lower Indus River (D; S1487), Holocene Delta (E; sample TH10_8 in Clift et al., 2010) and lower Pleistocene Fan (F; sample U1456 39F1W130/132, collected during IODP Expedition 355; Pandey et al., 2016) are notably poorer in feldspars and richer in quartz, metasedimentary rock fragments and micas relatively to Thal dunes. All samples with crossed polarizers; blue bar for scale $=100 \mu \mathrm{m}$.

Figure 4. Detrital modes of Thal Desert dunes compared with sand carried by the Upper Indus and its tributaries draining the diverse geological domains of the western Himalayan syntaxis (QFL and LmLvLs diagrams after Ingersoll et al., 1984). Thal dune sand contains more feldspars, more volcanic, metavolcanic, and metabasite rock fragments, more heavy minerals, and more hypersthene than modern Upper Indus sand, indicating greater contribution from the Kohistan arc. 
$999 \mathrm{Q}=$ quartz; $\mathrm{F}=$ feldspar; $\mathrm{L}=$ lithic grains $(\mathrm{Lm}=$ metamorphic $; \mathrm{Lv}=$ volcanic; $\mathrm{Ls}=$ sedimentary $)$;

$10 \frac{1}{2} 0$ other parameters as in Table 1. Data in the LmLvLs and heavy-mineral triangular diagrams are 3 centered to allow better visualization (von Eynatten et al., 2002).

1092

Figure 5. U-Pb age spectra of detrital zircons in Thal dunes and in sands carried by the Upper Indus and its tributaries. Zanskar data after Jonell et al. (2017a); Dir and most Upper Hunza ages after Zhuang et al. (2018). Main events of crustal growth in the western Himalayas are indicated. The multimodal spectrum of Thal sand indicates dominant zircon supply from the western Himalayan syntaxis, including the Karakorum Range (Baltoro granite, South Karakorum gneiss domes, and central batholith) and Transhimalayan arcs (ages from 20 to $130 \mathrm{Ma}$ ), together with the Nanga Parbat massif (sharp $1.85 \mathrm{Ga}$ peak). Contribution from the Greater and Tethys Himalaya is subordinate (mostly Neoproterozoic ages).

Figure 6. Sedimentary geochemistry. Elements are arranged following the periodic table group by group and data are normalized to the median composition of average Upper Indus (A) and Lower Indus sand (B) (Appendix Table A6). A) Note: i) similar composition of Thal Desert and Upper Indus sands, which have higher concentration in most chemical elements relatively to Himalayanderived sand; ii) peculiar composition of Kohistan sand, with high $\mathrm{Mg}, \mathrm{Sc}, \mathrm{V}, \mathrm{Co}, \mathrm{Ni}$ and $\mathrm{Cu}$, and low $\mathrm{Th}, \mathrm{U} \mathrm{Nb}$, Ta, and $\mathrm{Eu}$ anomaly; iii) low $\mathrm{Cr}$ and $\mathrm{Ni}$ in Ladakh sand; iv) heavy-mineral enrichment and strongly negative $\mathrm{Eu}$ anomaly in Hispar sand, owing to a local selectiveentrainment effect. B) Note: i) both Thal Desert and Upper Indus sands have higher concentration in most chemical elements than Himalayan-derived sand of Punjab tributaries; ii) high K, Rb, V, Ni and $\mathrm{Cu}$ in finer-grained sediments of the LGM to Holocene Indus Delta (data after Clift et al., 2010); iii) markedly variable Eu anomaly in both Thal Desert and Punjab tributary sands chiefly controlled by local selective-entrainment effects (Garzanti et al., 2010). 
1025 Figure 7. MDS maps based on electron-microprobe chemical analyses of amphibole, garnet,

1026 3 1027 5 $10 \frac{1}{8} 8$ 8 1029 10 1030 12 13 1041 15 17932 17 11833 20 18134 22 12335 25 12636 27 14837 30 13038 32 13339 34 35 350 37 13841 39

1442 42 140843 44 14544 47 14845 49 15946 51 52 15037 54 $15 \sqrt{48}$ 56 1574 59 1650 61

epidote, and pyroxene (mod. after figure 7 in Liang et al., 2019). The Kohistan arc is indicated as the main supplier of epidote $(\mathbf{A})$ and pyroxene $(\mathbf{B})$, whereas amphibole $(\mathbf{C})$ and garnet $(\mathbf{D})$ were largely derived from the Karakorum Range (Hispar River), Nanga Parbat massif, and Himalayan belt.

Figure 8. MDS maps based on U-Pb age spectra of detrital zircons highlight focused erosion of the western Himalayan syntaxis at LGM times and increasing contributions from the Himalayan belt in the Holocene. A) Thal dunes show a greater affinity with Transhimalayan arcs than Upper Indus sand. Zanskar data after Jonell et al. (2017a); Dir, Kabul, and most Upper Hunza ages after Zhuang et al. (2018). B) Sands of the Lower Indus, Thar dunes, and Pleistocene Fan plot close to Himalayan tributaries of the Punjab, showing strong Himalayan influence. Instead, Holocene and especially LGM Delta sands display closer affinity to sands of the Upper Indus, Thal dunes, and Transhimalayan arcs. Data sources: Punjab tributaries and Thar Desert (Alizai et al., 2011); Lower Indus River (Clift et al., 2004); LGM to Holocene Indus Delta (Clift et al., 2008, 2010; 4 samples combined from Thatta, Jati, and Keti Bandar cores, age 6.6-9.7 ka, n=288; 2 samples combined from Keti Bandar core, age 28.7 ka, n=229); Indus Canyon (Li et al., 2019; 6 samples combined, age 0.4-6.7 ka, n=507); Indus Fan (Clift et al., 2019; sample U1456A-11H-6 60/69, age 0.9 ka). Eastern Karakorum: Hushe + Braldu samples; western Karakorum: Upper Hunza + Hispar samples.

Figure 9. Petrography and heavy minerals in Indus River sands, from the western Himalayan syntaxis to the deep sea. A) Quartz increases downstream of the Thal Desert because of major supply from Punjab tributaries draining the Himalayan belt. Rock fragments are dominantly sedimentary in sand from the Kirthar Range but locally include volcanic/metavolcanic and ultramafic types shed by the Waziristan and Zhob ophiolites in sand from the Sulaiman Range. Otherwise, modern sand in the Indus sedimentary system includes a variety of sedimentary and 
1051 metamorphic grains with subordinate volcanic/metavolcanic types. Volcanic rock fragments are $10 \frac{1}{2} 2$ most abundant in the Kamlial Formation, reflecting incipient dissection of the Kohistan arc at mid3 1053 5 1054 8 1055 10 1056 12 13 1.057 15 17538 17 17959 20 18160 22

Miocene times (Najman et al., 2003). B) A progressive shift in detrital modes indicates increasing contribution from Himalayan tributaries of the Punjab from Miocene-Pleistocene fan turbidites to Holocene deltaic and modern Lower Indus fluvio-deltaic sands (light grey arrow). Q = quartz; F = feldspar; L = lithic grains; Ky = kyanite; Sil = sillimanite; Sp = Cr-spinel; St = staurolite; other parameters as in Table 1. Data sources: modern sand (Garzanti et al., 2005), LGM to Holocene Delta (Clift et al., 2010), Upper Miocene-Pleistocene Fan, IODP sites U1456 and U1457 (Garzanti et al., 2020).

Figure 10. Drastically changing landscapes in the western Himalayan foreland basin driven by latest Quaternary climate change. Pictures in rectangles aim at representing natural sceneries and life conditions at the time, from mountain higlands to the coastal plain. Circles represent rough proportions of detritus contributed by the Upper Indus (orange dots) versus the Himalayan tributaries of the Punjab (blue dots). A) In the dry latest Pleistocene, during deglaciation following the LGM, sediment fluxes were largely generated by incision of moraines and fluvial terraces in the high Kohistan and Karakorum Ranges surrounding the western Himalayan syntaxis. B) In the wet early Holocene, water and sediment fluxes were instead largely fuelled by heavy rainfall along the southern front of the Himalayan belt directly hit by humid air masses brought in by the intensified summer monsoon.

Table 1. Petrographic and heavy-mineral signatures of Thal Desert sand compared with sands carried by the Indus River and its tributaries draining different source-rock domains. Data sources: Miocene Kamlial Formation (Najman et al., 2003); Indus Delta cores (Clift et al., 2010); modern Indus sands and Neogene Indus Fan turbidites (Garzanti et al., 2005, 2020). Q = quartz; F = feldspars $(\mathrm{KF}=\mathrm{K}$-feldspar; $\mathrm{P}=$ plagioclase $; \mathrm{L}=$ lithic grains $(\mathrm{Lvm}=$ volcanic and metavolcanic; $\mathrm{Lc}$ 
1077 = carbonate and metacarbonate Lh = chert Lsm = shale, siltstone, slate, and metasiltstone; $\mathrm{Lmf}=$

$10 \frac{1}{2} 8$ felsic metamorphic; $\mathrm{Lmb}=$ metabasite; $\mathrm{Lu}=$ ultramafic); $\mathrm{HM}=$ heavy minerals; $\mathrm{MI}^{*}=$ 3

1079 Metamorphic Index; tHMC $=$ transparent heavy-mineral concentration. ZTR $=$ zircon + tourmaline 5

$10 \frac{8}{8} 0$ + rutile; Ttn = titanite; Ep = epidote-group minerals; Grt = garnet; SKS = staurolite + kyanite + 8

1081 sillimanite; Amp = amphibole; $\mathrm{Px}=$ pyroxene $(\mathrm{Cpx}=$ clinopyroxene Opx $=$ orthopyroxene, mostly 10

10 hypersthene); \&tHM = other transparent heavy minerals (apatite, chloritoid, Cr-spinel, olivine, 11383 prehnite, pumpellyite, brookite, andalusite, barite).

17884

17 
1085

$10 \frac{1}{2} 6$

1087

1088

6

7

1089

1090 11

${ }_{13}^{12} 1$

1 (1) 2

15

16

11)93

18

1094

2095 22

10396

12857

26

27

1288

29

13099

13100

1331

35

$1316) 2$

37

1318)

39

1404

$14 \sqrt{4} 25$

43

1,106

$1_{47}^{4} 907$

48

141908

50

15109

52

15130

54

1551

${ }_{58}^{57}$

15913

16114

62

63

64

65

\section{REFERENCES}

Ahmad, T., Harris, N., Bickle, M., Chapman, H., Bunbury, J., Prince, C., 2000. Isotopic constraints on the structural relationships between the Lesser Himalayan Series and the High Himalayan Crystalline Series, Garhwal Himalaya. Geological Society of America Bulletin, 112, 467-477.

Ali, K.F., De Boer, D.H., 2007. Spatial patterns and variation of suspended sediment yield in the upper Indus River basin, northern Pakistan. Journal of Hydrology, 334, 368-387.

Ali, K.F., De Boer, D.H., 2008. Factors controlling specific sediment yield in the upper Indus River basin, northern Pakistan. Hydrological Processes, 22, 3102-3114.

Alizai, A., Carter, A., Clift, P.D., Van Laningham, S., Williams, J.C., Kumar, R., 2011. Sediment provenance, reworking and transport processes in the Indus River by U-Pb dating of detrital zircon grains. Global and Planetary Change, 76, 33-55.

Alizai, A., Clift, P.D., Still, J., 2016. Indus Basin sediment provenance constrained using garnet geochemistry. Journal of Asian Earth Sciences, 126, 29-57.

Andò, S., Garzanti, E., 2014. Raman spectroscopy in heavy-mineral studies. In: Scott, R.A., Smyth, H.R., Morton, A.C., Richardson, N. (Eds.), Sediment Provenance Studies in Hydrocarbon Exploration and Production. Geological Society: London, UK, Special Publication 386, pp. 395412 .

Andò, S., Aharonovich, S., Hahn, A., George, S.C., Clift, P.D., Garzanti, E., 2019. Integrating heavy-mineral, geochemical, and biomarker analyses of Plio-Pleistocene sandy and silty turbidites: a novel approach for provenance studies (Indus Fan, IODP Expedition 355). Geological Magazine, https://doi.org/10.1017/S0016756819000773

Argles, T., Foster, G., Whittington, A., Harris, N., George, M., 2003. Isotope studies reveal a complete Himalayan section in the Nanga Parbat syntaxis. Geology, 31(12), 1109-1112.

Badshah, M.S., Gnos, E., Jan, M.Q., Afridi, M.I., 2000. Stratigraphic and tectonic evolution of the northwestern Indian plate and Kabul Block. Geological Society, London, Special Publications, $170,467-476$.

Beck, R.A., Burbank, D.W., Sercombe, W.J., Riley, G.W., Barndt, J.K., Berry, J.R., Afzal, J., Khan, A.M., Jurgen, H., Metje, J., Cheema, A., Shafique, N.A., Lawrence, R.D., Khan, M.A., 1995. Stratigraphic evidence for an early collision between Northwest India and Asia. Nature, 373 (6509), 55-58. 
1115 Biagi, P., Starnini, E., Ghauri, Z.S., 2019. Mahi Wala 1 (MW-1): a Mesolithic site in the Thal desert 1116 of Punjab (Pakistan). Asian Archaeology, https://doi.org/10.1007/s41826-019-00024-z.

2

1137

$11_{6}^{5} 8$

$11_{8}^{7} 19$

9

1120

11

1121

13

1142

15

16

11723

1724

1325

22

14326

24

12527

26

12728

28

139

13130

131331

34

35

13162

13733

1394

1435

43

14146

45

1467

47

49

${ }_{51}^{5} 39$

15240

53

54

151541

56

1542

58

59

60

61

62

63

64

65

Blöthe, J.H., Munack, H., Korup, O., Fülling, A., Garzanti, E., Resentini, A., Kubik. P.W., 2014. Late Quaternary valley infill and dissection in the Indus River, western Tibetan Plateau margin. Quaternary Science Reviews, 94, 102-119.

Borromeo, L., Andò, S., France-Lanord, C., Coletti, G., Hahn, A., Garzanti, E., 2019. Provenance of Bengal Shelf Sediments: 1. Mineralogy and Geochemistry of Silt. Minerals, 9, 640, doi:10.3390/min9100640.

Burbank, D.W., Leland, J., Fielding, E., Anderson, R.S., Brozovic, N., Reid, M.R., Duncan, C., 1996a. Bedrock incision, rock uplift and threshold hillslopes in the northwestern Himalayas. Nature, 379, 505-510.

Burbank, D.W., Beck, R.A., Mulder, T., 1996b. The Himalayan foreland basin. In: Yin, A., Harrison, T.M. (Eds.), The Tectonic Evolution of Asia (World and regional geology). Cambridge University Press, Cambridge, UK, pp.149-188.

Burg, J.P., 2011. The Asia-Kohistan-India collision: review and discussion. In: Brown, D., Ryan, P.D. (Eds.), Arc-Continent Collision, Frontiers in Earth Sciences, Springer Berlin Heidelberg, pp. 279-309.

Cerveny, P.F., Johnson, N.M., Tahirkheli, R.A.K., Bonis, N.R., 1989. Tectonic and geomorphic implications of Siwalik group heavy minerals, Potwar plateau, Pakistan. In: Malinconico, L.L., Lillie, R.J. (Eds.), Tectonics of the Western Himalayas. Geological Society of America, Special Papers, 232, pp. 129-136.

Chirouze, F., Huyghe, P., Chauvel, C., van der Beek, P., Bernet, M., Mugnier, J.-L., 2015. Stable drainage pattern and variable exhumation in the Western Himalaya since the Middle Miocene. The Journal of Geology, 123, 1-20, doi.org/10.1086/679305.

Clift, P.D., 2017. Cenozoic sedimentary records of climate-tectonic coupling in the Western Himalaya. Progress in Earth and Planetary Science, 4, 39, doi10.1186/s40645-017-0151-8.

Clift, P.D., Giosan, L., 2014. Sediment fluxes and buffering in the post-glacial Indus Basin. Basin Research, 26, 369-386, doi:10.1111/bre.12038. 
1143

1144 1245 4 $1 \frac{5}{6} 6$ $11_{8}^{7} 47$ 11948 10 11 11249 1350 1,51 ${ }_{18}^{17} 752$ 19 12क 3 21 12154 23 155 25

1356 1497 29 1358 31 13159 33

1340 ${ }_{3}^{3} 61$ 13882 39 14163 41 141264 43 1445 45

14966 1487 15168 51 52 15169 54 1550 56 1587 15192 60 61 62

Clift, P., Shimizu, N., Layne, G., Gaedicke, C., Schlter, H.U., Clark, M., Amjad, S., 2000. Fifty-five million years of Tibetan evolution recorded in the Indus Fan. Eos, Transactions American Geophysical Union, 81, 277-281.

Clift, P.D., Shimizu, N., Layne, G., Blusztajn, J.S., Gaedicke, C., Schluter, H.-U., Clark, M.K., Amjad, S., 2001. Development of the Indus Fan and its significance for the erosional history of the Western Himalaya and Karakoram. Geological Society of America Bulletin, 113, 1039-1051.

Clift, P.D., Lee, J.I., Hildebrand, P., Shimizu, N., Layne, G.D., Blusztajn, J., Blum, J.D., Garzanti, E., Khan, A.A., 2002. Nd and Pb isotope variability in the Indus River System: implications for sediment provenance and crustal heterogeneity in the Western Himalaya. Earth and Planetary Science Letters, 200(1-2), 91-106.

Clift, P.D., Campbell, I.H., Pringle, M.S., Carter, A., Zhang, X., Hodges, K.V., Khan, A.A., Allen, C.M., 2004. Thermochronology of the modern Indus River bedload: New insight into the controls on the marine stratigraphic record. Tectonics, 23(5), doi:10.1029/2003TC001559.

Clift, P., Giosan, L., Blusztajn, J., Campbell, I.H., Allen, C., Pringle, M., Tabrez, A.R., Danish, M., Rabbani, M.M., Alizai, A., Carter, A., Lückge, A., 2008. Holocene erosion of the Lesser Himalaya triggered by intensified summer monsoon. Geology, 36, 79-82, doi: 10.1130/G24315A.1.

Clift P.D., Giosan L., Carter A., Garzanti E., Galy V., Tabrez A.R., Pringle M., Campbell I.H., France-Lanord C., Blusztajn J., Allen C., Alizai A., Lückge A., Danish M., Rabbbani M.M., 2010. Monsoon control over erosion patterns in the Western Himalaya: possible feed-backs into the tectonic evolution. In: Clift P.D., Tada R. and Zheng H. (Eds.), Monsoon evolution and tectonic-climate linkage in Asia, Geological Society London, Special Publication 342, pp. 185218

Clift, P.D., Carter, A., Giosan, L., Durcan, J., Duller, G.A., Macklin, M.G., Alizai, A., Tabrez, A.R., Danish, M., Van Laningham, S., Fuller, D.Q., 2012. U-Pb zircon dating evidence for a Pleistocene Sarasvati River and capture of the Yamuna River. Geology, 40(3), 211-214.

Clift, P.D., Zhou, P., Stockli, D.F., Blusztajn, J., 2019. Regional Pliocene exhumation of the Lesser Himalaya in the Indus drainage. Solid Earth, 10, 647-661.

Comas-Cufí, M., Thió-Henestrosa, F.S., 2011. CoDaPack 2.0: a stand-alone, multi-platform compositional software. 
1173 Cottle, J., Lederer, G., Larson, K., 2019. The monazite record of pluton assembly: Mapping 11174 Manaslu using petrochronology, Chemical Geology, 530, 119309,

$1 \frac{2}{13} 5$ 4

$11 \frac{5}{6} 6$ 1177 1198 10

117 129 https://doi.org/10.1016/j.chemgeo.2019.119309.

Crawford, M.B., Searle, M.P., 1992. Field relationships and geochemistry of pre-collisional (IndiaAsia) granitoid magmatism in the central Karakoram, northern Pakistan. Tectonophysics, 206, 171-192.

Critelli, S., Garzanti, E., 1994. Provenance of the Lower Tertiary Murree redbeds (Hazara-Kashmir syntaxis, Pakistan) and initial rising of the Himalayas. Sedimentary Geology, 89, 265-284.

Critelli, S., Ingersoll, R.V., 1994. Sandstone petrology and provenance of the Siwalik Group (northwestern Pakistan and western-southeastern Nepal). Journal of Sedimentary Research, A64, 815-823.

Critelli, S., De Rosa, R., Platt, J.P., 1990. Sandstone detrital modes in the Makran accretionary wedge, southwest Pakistan: Implications for tectonic setting and long-distance turbidite transportation. Sedimentary Geology, 68, 241-260.

Debon, F., Le Fort, P., Dautel, D., Sonet, J., Zimmermann, J.L., 1987. Granites of western Karakorum and northern Kohistan (Pakistan): A composite Mid-Cretaceous to upper Cenozoic magmatism. Lithos, 20(1), 19-40.

DeCelles, P., Gehrels, G.E., Quade, J., LaReau, B., Spurlin, M., 2000. Tectonic implications of U$\mathrm{Pb}$ zircon ages of the Himalayan orogenic belt in Nepal. Science, 288, 497-499, doi: 10.1126/science.288.5465.497.

DePaolo, D.J., Wasserburg, G.J., 1976. Nd isotopic variations and petrogenetic models. Geophysical Research Letters, 3, 249-252.

DiPietro, J.A., Pogue, K.R., 2004. Tectonostratigraphic subdivisions of the Himalaya: A view from the west. Tectonics, 23, TC5001, doi:10.1029/2003TC001554.

Dixit, Y., Hodell, D.A., Petrie, C.A., 2014. Abrupt weakening of the summer monsoon in northwest India 4100 yr ago. Geology, 42(4), 339-342, doi:10.1130/G35236.1.

Dhir, R.P., Singhvi, A.K., Andrews, J.E., Kar, A., Sareen, B.K., Tandon, S.K., Kailath, A., Thomas, J.V., 2010. Multiple episodes of aggradation and calcrete formation in late Quaternary aeolian sands, central Thar Desert, Rajasthan, India. Journal of Asian Earth Sciences, 37, 10-16. 
1202

1203

126) 4

4

1255

12706

1207

10

11

1208

1309

155

17

1281

19

12012

21

12213

23

124 14

1295

28

1296

30

13217

32

1328

34

1359

1320

39

1421

41

1422

43

1223

45

$1 \frac{42}{4} 4$

14225

50

15226

52

1527

54

${ }_{56}^{53} 8$

523
58

15930

60

$12 B 1$

62

63

64

65

Downing, K.F., Lindsay, E.H.., 2005. Relationship of Chitarwata Formation paleodrainage and paleoenvironments to Himalayan tectonics and Indus River paleogeography. Palaeontologia Electronica, 8, 1; 20A, 12 p.

East, A.E., Clift, P.D., Carter, A., Alizai, A., Van Laningham, S., 2015. Fluvial-eolian interactions in sediment routing and sedimentary signal buffering: an example from the Indus Basin and Thar Desert. Journal of Sedimentary Research, 85, 715-728.

Enzel, Y., Ely, L.L., Mishra, S., Ramesh, R., Amit, R., Lazar, B., Rajaguru, S.N., Baker, V.R., Sandler, A., 1999. High-resolution Holocene environmental changes in the Thar Desert, northwestern India. Science, 284, 125-128.

Fraser, J.E., Searle, M.P., Parrish, R.R., Noble, S.R., 2001. Chronology of deformation, metamorphism, and magmatism in the southern Karakoram Mountains. Geological Society of America Bulletin, 113 (11), 1443-1455-

Gabriel, K.R., 1971. The biplot graphic display of matrices with application to principal component analysis. Biometrika, 58, 453-467.

Gaetani, M., Garzanti, E., Jadoul, F., Nicora, A., Tintori, A., Pasini, M., Kanwar, S.A.K., 1990, The north Karakorum side of the Central Asia geopuzzle. Geological Society of America Bulletin, $102,54-62$.

Galehouse, J.S., 1971. Point counting, In: Carver, R.E. (ed.), Procedures in sedimentary petrology, New York, Wiley, pp. 385-407.

Garçon, M., Chauvel, C., France-Lanord, C., Limonta, M., Garzanti, E., 2014. Which minerals control the Nd-Hf-Sr-Pb isotopic compositions of river sediments? Chemical Geology, 364, 4255.

Garzanti, E., 2016. From static to dynamic provenance analysis-Sedimentary petrology upgraded. Sedimentary Geology, 336, 3-13.

Garzanti, E., 2017, The maturity myth in sedimentology and provenance analysis. Journal of Sedimentary Research, 87, 353-365.

Garzanti, E., 2019a. The Himalayan foreland basin from collision onset to the present: a sedimentary-petrology perspective. In: Treloar, P., Searle, M.P. (Eds.), Himalayan tectonics: a modern synthesis. Geological Society London, Special Publication 483, 65-122, doi.org: 10.1144/SP483.17 
1232 Garzanti, E., 2019b. Petrographic classification of sand and sandstone. Earth-Science Reviews, 192,

$12 B 3$

2

$12 \frac{3}{4} 4$

$12 \frac{5}{6} 5$

7

12836

1 1DO37

11

12

11238

$1, \frac{1}{12} 39$

16

$1 \frac{17}{18} 40$

12941

20

21

12242

1243 25

$\frac{1394}{27}$

12845

29

30

13446

32

$13-37$

1348 36

1349

38

13250

40

14251

42

1252

$1 \frac{453}{46}$

14254

48

15055

51

15256

1537

55

1558

15259 545-563.

Garzanti, E., Andò, S., 2019. Heavy Minerals for Junior Woodchucks. Minerals, 9, 148, https://doi.org/10.3390/min9030148.

Garzanti, E., Resentini, A., 2016. Provenance control on chemical indices of weathering (Taiwan river sands). Sedimentary Geology, 336, 81-95.

Garzanti, E., Van Haver, T., 1988. The Indus clastics: forearc basin sedimentation in the Ladakh Himalaya (India). Sedimentary Geology, 59(3-4), 237-249.

Garzanti, E., Vezzoli, G., 2003. A classification of metamorphic grains in sands based on their composition and grade Journal of Sedimentary Research, 73, 830-837.

Garzanti, E., Casnedi, R., Jadoul, F., 1986. Sedimentary evidence of a Cambro-Ordovician orogenic event in the northwestern Himalaya. Sedimentary Geology, 48, 237-265.

Garzanti, E., Baud, A., Mascle, G., 1987. Sedimentary record of the northward flight of India and its collision with Eurasia (Ladakh Himalaya, India). Geodinamica Acta, 1, 297-312.

Garzanti, E., Critelli, S., Ingersoll, R.V., 1996. Paleogeographic and paleotectonic evolution of the Himalayan Range as reflected by detrital modes of Tertiary sandstones and modern sands (Indus transect, India and Pakistan). Geological Society of America Bulletin, 108, 631-642.

Garzanti, E., Vezzoli, G., Andò, S., Paparella, P., Clift, P.D., 2005. Petrology of Indus River sands: a key to interpret erosion history of the Western Himalayan Syntaxis. Earth and Planetary Science Letters, 229, 287-302.

Garzanti, E., Andò, S., France-Lanord, C., Vezzoli, G., Najman, Y., 2010. Mineralogical and chemical variability of fluvial sediments. 1. Bedload sand (Ganga-Brahmaputra, Bangladesh). Earth Planetary Science Letters, 299, 368-381.

Garzanti, E., Andò, S., France-Lanord, C., Galy, V., Censi, P., Vignola, P., 2011. Mineralogical and chemical variability of fluvial sediments. 2. Suspended-load silt (Ganga-Brahmaputra, Bangladesh). Earth and Planetary Science Letters, 302, 107-120.

Garzanti, E., Resentini, A., Vezzoli, G., Andò, S., Malusà, M., Padoan, M., 2012. Forward compositional modelling of Alpine orogenic sediments. Sedimentary Geology, 280, 149-164. 
1260 Garzanti, E., Vermeesch, P., Rittner, M. and Simmons, M., 2018. The zircon story of the Nile: 1261 Time- structure maps of source rocks and discontinuous propagation of detrital signals. Basin

Garzanti, E., Andò, S., France-Lanord, C., Limonta, M., Borromeo, L., Vezzoli, G., 2019. Provenance of Bengal Shelf Sediments. 2. Petrology of sand. Minerals, 9, 642; doi:10.3390/min9100642.

Garzanti, E., Andò, S., Vezzoli, G., 2020. Provenance of Cenozoic Indus Fan sediments (IODP Sites U1456 and U1457). Journal of Sedimentary Research, in press.

Gehrels, G.E., DeCelles, P.G., Martin, A., Ojha, T.P., Pinhassi, G., Upreti, B.N., 2003. Initiation of the Himalayan Orogen as an early Paleozoic thin-skinned thrust belt. GSA Today, 13(9), 4-9.

Gehrels, G., Kapp, P., DeCelles, P., Pullen, A., Blakey, R., Weislogel, A., Ding, L., Guynn, J., Martin, A., McQuarrie, N., Yin, A., 2011. Detrital zircon geochronology of pre- Tertiary strata in the Tibetan- Himalayan orogen. Tectonics, 30, TC5016, doi:10.1029/2011TC002868.

Giosan, L., Constantinescu, S., Clift, P.D., Tabrez, A.R., Danish, M., Inam, A., 2006a. Recent morphodynamics of the Indus delta shore and shelf. Continental Shelf Research, 26, 1668-1684.

Giosan, L., Clift, P.D., Blusztajn, J., Tabrez, A., Constantinescu, S., Filip, F., 2006b. On the control of climate- and human-modulated fluvial sediment delivery on river delta development: The Indus. Eos, Transactions, American Geophysical Union, 87, AGU Fall Meeting Abstracts, OS14A-04.

Giosan, L., Clift, P.D., Macklin, M.G., Fuller, D.Q., Constantinescu, S., Durcan, J.A., Stevens, T., Duller, G.A.T., Tabrez, A.R., Gangal, K., Adhikari, R., Alizai, A., Filip, F., Van Laningham, S., Syvitski, J.P.M., 2012. Fluvial landscapes of the Harappan civilization. Proceedings of the National Academy of Sciences, 109, 1688-1694, doi/10.1073/pnas.1112743109.

Gnos, E., Immenhauser, A., Peters, T.J., 1997. Late Cretaceous/early Tertiary convergence between the Indian and Arabian plates recorded in ophiolites and related sediments. Tectonophysics, 271, $1-19$.

Goodbred, S.L., Kuehl, S.A., 2000. Enormous Ganges-Brahmaputra sediment discharge during strengthened early Holocene monsoon. Geology, 28, 1083-1086.

Gosal, G., 2004. Physical geography of the Punjab. Journal of Punjab Studies, 11, 19-37. 
1289

1290

12. 1

1292

6

1293

1294

10

1205

12

1296

14

${ }_{16}^{15} 7$

$1 \frac{13}{18}$

1129) 9

20

21

12300

23

1352

13303

29

1304

31

13205

33

13466

35

$1_{37}^{36} 7$

13308

39

40

14109

42

14310

1431

46

13712

1493

50

51

15214

53

1545

1356

$1_{58}^{57} 17$

59

60

61

62

63

64

65

Greenman, D.W., Swarzenski, W.V., Bennett, G.D., 1967. Ground-water hydrology of the Punjab, West Pakistan, with emphasis on problems caused by canal irrigation. United States Government Printing Office, Washington, United Stated Geological Survey, Water-supply paper 1608H, 166.

Griffin, W.L., Powell, W.J., Pearson, N.J., O'Reilly, S.Y., 2008. GLITTER: data reduction software for laser ablation ICP-MS. In: Sylvester, P. (Ed.), Laser ablation-ICP-MS in the earth sciences: current practices and outstanding issues. Mineralogical Association of Canada, Short Course 40, pp. 204-207.

Hamilton, P.J., O'Nions, R.K., Bridgwater, D., Nutman, A.P., 1983. Sm-Nd studies of Archaean metasediments and metavolcanics from west Greenland and their implications for the Earth's early history. Earth and Planetary Science Letters, 62, 263-272.

Henderson, A.L., Najman, Y., Parrish, R., BouDagher- Fadel, M., Barford, D., Garzanti, E., Andò, S., 2010. Geology of the Cenozoic Indus Basin sedimentary rocks: Paleoenvironmental interpretation of sedimentation from the western Himalaya during the early phases of India- Eurasia collision. Tectonics, 29(6), TC6015, doi:10.1029/2009TC002651.

Hildebrand, P.R., Noble, S.R., Searle, M.P., Waters, D.J., Parrish, R.R., 2001. Old origin for an active mountain range: Geology and geochronology of the eastern Hindu Kush, Pakistan. Geological Society of America Bulletin, 113, 625-639.

Hu, X., Garzanti, E., Moore, T., Raffi, I., 2015. Direct stratigraphic dating of India-Asia collision onset at the Selandian (middle Paleocene, 59 \pm 1 Ma). Geology, 43(10), 859-862.

Hubert, J.F., 1962. A zircon-tourmaline-rutile maturity index and the interdependence of the composition of heavy minerals assemblages with the gross composition and texture of sandstones. Journal of Sedimentary Petrology, 32, 440-450.

Hussain, A., Mir, H., Afzal, M., 2005. Analysis of dust storms frequency over Pakistan during 1961-2000. Pakistan Jounal of Meteorology, 2, 49-68.

Hussain, Y., Ullah, S.F., Hussain, M.B., Aslam, A.Q., Akhter, G., Martinez-Carvajal, H., CárdenasSoto, M., 2017. Modelling the vulnerability of groundwater to contamination in an unconfined alluvial aquifer in Pakistan. Environmental Earth Sciences, 76, 84, doi:10.1007/s12665-0176391-5. 
1318 Ingersoll, R.V., Bullard, T.F., Ford, R.L., Grimm, J.P., Pickle, J.D., Sares, S.W., 1984. The effect of 13119 grain size on detrital modes: a test of the Gazzi-Dickinson point-counting method. Journal of

Jadoon, I.A., Lawrence, R.D., Lillie, R.J., 1994. Seismic data, geometry, evolution, and shortening in the active Sulaiman fold-and-thrust belt of Pakistan, southwest of the Himalayas. American Association of Petroleum Geologists Bulletin, 78, 758-774.

Jagoutz, O.E., Burg, J.P., Hussain, S., Dawood, H., Pettke, T., Iizuka, T., Maruyama, S., 2009. Construction of the granitoid crust of an island arc part I: geochronological and geochemical constraints from the plutonic Kohistan (NW Pakistan). Contributions to Mineralogy and Petrology, 158, 739-755.

Jagoutz, O., Bouilhol, P., Schaltegger, U., Müntener, O., 2019. The isotopic evolution of the Kohistan Ladakh arc from subduction initiation to continent arc collision. In: Treloar, P.J., Searle, M.P. (Eds.), Himalayan Tectonics: A Modern Synthesis. Geological Society, London, Special Publications, 483, 165-182.

Jipa, D., Kidd, R.B., 1974. Sedimentation of coarser grained interbeds in the Arabian Sea and sedimentation processes of the Indus Cone. In: Whitmarsh, R.B., Weser, O.E., Ross, D.A., et al. (Eds.), Initial Report of the Deep Sea Drilling Project 219-230. Washington, D.C., US Government Printing Office, pp. 471-495.

Jonell, T.N., Carter, A., Böning, P., Pahnke, K., Clift, P.D., 2017a. Climatic and glacial impact on erosion patterns and sediment provenance in the Himalayan rain shadow, Zanskar River, NW India. Geological Society of America Bulletin, 129, 820-836.

Jonell, T.N., Owen, L.A., Carter, A., Schwenniger, J. L., Clift, P.D., 2017b. Quantifying episodic erosion and transient storage on the western margin of the Tibetan Plateau, upper Indus River. Quaternary Research, 89(1), 281-306.

Jonell, T.N., Li, Y., Blusztajn, J., Giosan, L., Clift, P.D., 2018. Signal or noise? Isolating grain size effects on $\mathrm{Nd}$ and $\mathrm{Sr}$ isotope variability in Indus delta sediment provenance. Chemical Geology, 485, 56-73.

Kadri, I.B., 1995. Petroleum Geology of Pakistan. Pakistan Petroleum Limited (275 pp.).

Khan, I.A., Bridge, J.S., Kappelman, J., Wilson, R., 1997a. Evolution of Miocene fluvial environments, eastern Potwar plateau, northern Pakistan. Sedimentology, 44, 221-251. 
1348

1349

1350

4

1351

13752

9

1Bक 3

11

1354

135

15

$1 \frac{1356}{35}$

1397

19

20

12558

22

12359

1340

26

12561

28

12362

30

13363

32

13364

34

13555

36

13366

38

13367

40

1468

42

13359

44

14570

46

1471

48

$1 \frac{49}{5} 2$

$1_{52}^{57} 3$

53

15374

55

1565

57

1536

1307

Khan, M.A., Stern, R.J., Gribble, R.F., Windley, B.F., 1997b. Geochemical and isotopic constraints on subduction polarity, magma sources and palaeogeography of the Kohistan intra-oceanic arc, northern Pakistan Himalayas. Journal of the Geological Society, London, 154, 935-946.

Kruskal, J., 1964. Multidimensional scaling by optimizing goodness of fit to a nonmetric hypothesis. Psychometrika, 29, 1-27.

Lee, J.I., Clift, P.D., Layne, G., Blum, J., Khan, A.A., 2003. Sediment flux in the modern Indus River inferred from the trace element composition of detrital amphibole grains. Sedimentary Geology, 160, 243-257.

Li, Y., Clift, P.D., O'Sullivan, P., 2019. Millennial and centennial variations in zircon U- Pb ages ìn the Quaternary Indus submarine canyon. Basin Research, 31, 155-170.

Liang, W., Garzanti, E., Andò, S., Gentile, P., Resentini, A., 2019. Multimineral fingerprinting of Transhimalayan and Himalayan sources to Indus-derived Thal Desert sand (central Pakistan). Minerals, 9, 457, doi:10.3390/min9080457.

Lünsdorf, N.K., Kalies, J., Ahlers, P., Dunkl, I., von Eynatten, H., 2019. Semi-automated heavymineral analysis by Raman spectroscopy. Minerals, 9, 385, doi.org/10.3390/min9070385.

Lupker, M., France-Lanord, C., Galy, V., Lavé, J., Kudrass, H., 2013. Increasing chemical weathering in the Himalayan system since the Last Glacial Maximum. Earth and Planetary Science Letters, 365, 243-252.

Mahar, M.A., Mahéo, G., Goodell, P.C., Pavlis, T.L., 2014. Age and origin of post collision Baltoro granites, south Karakoram, North Pakistan: Insights from in-situ U-Pb, Hf and oxygen isotopic record of zircons. Lithos, 205, 341-358.

Mahéo, G., Blichert-Toft, J., Pin, C., Guillot, S., Pêcher, A., 2009. Partial melting of mantle and crustal sources beneath South Karakorum, Pakistan: Implications for the Miocene geodynamic evolution of the India-Asia convergence zone. Journal of Petrology, 50, 427-449.

Mallik, T.K., 1978, Mineralogy of deep-sea sands of the Indian Ocean. Marine Geology, 27, 161176.

Malusà, M.G., Resentini, A., Garzanti, E., 2016. Hydraulic sorting and mineral fertility bias in detrital geochronology. Gondwana Research, 31, 1-19.

Mange, M.A., Maurer, H.F.W., 1992, Heavy minerals in colour. Chapman and Hall, London. (147 pp.). 
1378

13179

1330

4

$13 \frac{5}{6} 1$

13782

9

$1 B 83$

11

1384

1335

15

1366

13887

19

12388

21

22

12389

12300

$1_{2}^{2} 1$

1382

29

30

13293

32

13394

34
1355 36

1376

3897

40

1498

42

43

1499

14500

14701

49

15102

51

$15+23$

53

1544

15505

15406

59

60

61

62

63

64

65

Mange, M.A., Morton, A.C., 2007. Geochemistry of heavy minerals. In: Mange, M.A., Wright, D.T. (Eds.), Heavy Minerals in Use. Elsevier, Amsterdam, Developments in Sedimentology, 58, pp. 345-391.

Meadows, A., Meadows, P., 1999. The Indus River: Biodiversity, Resources, Humankind. Oxford University Press (441 pp.).

Miller, C., Klötzli, U., Frank, W., Thöni, M., Grasemann, B., 2000. Proterozoic crustal evolution in the NW Himalaya (India) as recorded by circa $1.80 \mathrm{Ga}$ mafic and $1.84 \mathrm{Ga}$ granitic magmatism. Precambrian Research, 103(3-4), 191-206.

Miller, C., Thöni, M., Frank, W., Grasemann, B., Klötzli, U., Guntli, P., Draganits, E., 2001. The early Palaeozoic magmatic event in the Northwest Himalaya, India: source, tectonic setting and age of emplacement. Geological Magazine, 138(3), 237-251.

Milliman, J.D., Quraishee, G.S. Beg, M.A.A., 1984. Sediment discharge from the Indus River to the ocean: past, present, and future. In: Haq, B.U., Milliman, J.D. (Eds.), Marine Geology and Oceanography of the Arabian Sea and Coastal Pakistan. Van Nostrand Reynolds, New York, pp. $65-70$.

Munack, H., Korup, O., Resentini, A., Limonta, M., Garzanti, E., Blöthe, J.H., Scherler, D., Wittmann, H., Kubik, P.W., 2014. Postglacial denudation of western Tibetan Plateau margin outpaced by long-term exhumation. Geological Society of America Bulletin, 126, 1580-1594.

Najman, Y., Garzanti, E., Pringle, M., Bickle, M., Stix, J., Khan, I., 2003. Early-Middle Miocene paleodrainage and tectonics in the Pakistan Himalaya. Geological Society of America Bulletin, 115, 1265-1277.

Nickson, R.T., McArthur, J.M., Shrestha, B., Kyaw-Myint, T.O., Lowry, D., 2005. Arsenic and other drinking water quality issues, Muzaffargarh District, Pakistan. Applied Geochemistry, 20, $55-68$.

Pandey, D.K., Clift, P.D., Kulhanek, D.K. \& Expedition 355 Scientists, 2016. Expedition 355 summary. Arabian Sea Monsoon. In: Pandey, D.K., Clift, P.D., Kulhanek, D.K. \& Expedition 355 Scientists (Eds.), Expedition 355 Scientific Prospectus: Arabian Sea Monsoon. Proceedings of the International Ocean Discovery Program, Volume 355. International Ocean Discovery Program, College Station, TX, 1-32, https://doi.org/10.14379/iodp.proc.355.101.2016. 
1407

1408

$\stackrel{2}{14999}$

4

$14 \frac{5}{6} 0$

$14_{8}^{71} 1$

1492

10

1 141 3

12

13

1444

$1 \frac{15}{16} 5$

14716

19

129 7

21

126ㄹ 8

23

1250

27

12821

29

30

13世区2

32

1323

34

$1 \frac{35}{36} 4$

13325

13926

40

41

14227

43

1428

1459

47

14830

49

151031

51

15632

53

1,533

15934

15835

59

161036

61

62

63

64

65

Parrish, R.R., Hodges, V., 1996. Isotopic constraints on the age and provenance of the Lesser and Greater Himalayan sequences, Nepalese Himalaya. Geological Society of America Bulletin,108, 904-911.

Pêcher, A., Seeber, L., Guillot, S., Jouanne, F., Kausar, A., Latif, M., Majid, A., Mahéo, G., Mugnier, J.L., Rolland, Y., van der Beek, P., Van Melle, J., 2008. Stress field evolution in the northwest Himalayan syntaxis, northern Pakistan. Tectonics, 27, TC6005, doi:10.1029/2007TC002252.

Petterson, M.G., M.B. Crawford, B.F. Windley, 1993. Petrogenetic implications of neodymium isotope data from the Kohistan Batholith, North Pakistan, Journal of the Geological Society, London, 150, 125-129.

Prasad, B.R., Klemperer, S.L., Rao, V.V., Tewari, H.C., Khare, P., 2011. Crustal structure beneath the Sub-Himalayan fold-thrust belt, Kangra recess, northwest India, from seismic reflection profiling: Implications for Late Paleoproterozoic orogenesis and modern earthquake hazard. Earth and Planetary Science Letters, 308(1-2), 218-228.

Prasad, S., Enzel, Y., 2006. Holocene palaeoclimates of India. Quaternary Research, 66, 442-453.

Qayyum, M., Lawrence, R.D., Niem, A.R., 1997. Discovery of the palaeo-Indus delta-fan complex. Journal of the Geological Society London, 154, 753-756, doi: 10.1144/gsjgs.154.5.0753.

Ravikant, V., Wu, F.Y., Ji, W.Q., 2009. Zircon U-Pb and Hf isotopic constraints on petrogenesis of the Cretaceous-Tertiary granites in eastern Karakoram and Ladakh, India. Lithos, 110(1-4), 153166.

Rehman, S.S., Sabir, M.A., Khan, J., 1997. Discharge characteristics and suspended load from rivers of Northern Indus Basin, Pakistan. Geological Bulletin University of Peshawar, 30, 325336.

Resentini, A., Goren, L., Castelltort, S., Garzanti, E., 2017. Partitioning the sediment flux by provenance and tracing erosion patterns in Taiwan. Journal Geophysical Research - Earth Surface, 122, 1430-1454, doi:10.1002/2016JF004026.

Roddaz, M., Said, A., Guillot, S., Antoine, P.O., Montel, J.M., Martin, F., Darrozes, J., 2011. Provenance of Cenozoic sedimentary rocks from the Sulaiman fold and thrust belt, Pakistan: implications for the palaeogeography of the Indus drainage system. Journal of the Geological Society, 168, 499-516. 
1437

$14 B 8$

1439

4

$1 \frac{54}{6} 0$

1441

1442

10

11

11243

13

1144

$\frac{15}{16} 5$

14746

19

12아7

21

121248

23

1249

25

12450

12951

29

13152

31

32

13153

$1 \frac{34}{35} 4$

13555

38

13956

40

14!57

42

1438

44

1459

14760

48

49

15151

51

15262

53

15463

55

1564

15865

Rolland, Y., Mahéo, G., Guillot, S., Pêcher, A., 2001. Tectono-metamorphic evolution of the Karakorum metamorphic complex (Dassu-Askole area, NE Pakistan): exhumation of mid-crustal HT-MP gneisses in a convergent context. Journal of Metamorphic Geology, 19, 717-737.

Rolland, Y., Picard, C., Pêcher, A., Lapierre, H., Bosch, D., Keller, F., 2002. The Cretaceous Ladakh arc of NW himalaya-slab melting and melt-mantle interaction during fast northward drift of Indian Plate. Chemical Geology, 182, 139-178.

Roy, P.D., Nagar, Y.C., Juyal, N., Smykatz-Kloss, W., Singhvi, A.K., 2009. Geochemical signatures of Late Holocene paleohydrological changes from Phulera and Pokharan saline playas near the eastern and western margins of the Thar Desert, India. Journal of Asian Earth Sciences $34,275-286$.

Rudnick, R.L., Gao, S., 2003. Composition of the continental crust. In: Rudnick, R.L., Holland, H.D., Turekian, K.K. (Eds.), Treatise on Geochemistry, The Crust. Elsevier Pergamon, Oxford, UK, Vol. 3, pp. 1-64.

Schärer, U., Copeland, P., Harrison, T. M., Searle, M.P., 1990. Age, cooling history, and origin of post-collisional leucogranites in the Karakoram Batholith; a multi-system isotope study. The Journal of Geology, 98(2), 233-251.

Schaltegger, U., Zeilinger, G., Frank, M., Burg, J.P., 2002. Multiple mantle sources during island arc magmatism: $\mathrm{U}-\mathrm{Pb}$ and $\mathrm{Hf}$ isotopic evidence from the Kohistan arc complex, Pakistan. Terra Nova, 14(6), 461-468.

Schneider, D.A., Zeitler, P.K., Kidd, W.S.F., Edwards, M.A., 2001. Geochronologic constraints on the tectonic evolution and exhumation of Nanga Parbat, western Himalaya syntaxis, revisited. The Journal of Geology, 109, 563-583.

Searle, M.P., 2013. Colliding continents: a geological exploration of the Himalaya, Karakoram, and Tibet. Oxford University Press, Oxford UK, 438 p.

Searle, M.P., Khan, M.A., Fraser, J.E., Gough, S.J., Jan, M.Q., 1999. The tectonic evolution of the Kohistan- Karakoram collision belt along the Karakoram Highway transect, north Pakistan. Tectonics, 18, 929-949.

Searle, M.P., Parrish, R.R., Thow, A.V., Noble, S.R., Phillips, R.J., Waters, D.J., 2010. Anatomy, age and evolution of a collisional mountain belt: the Baltoro granite batholith and Karakoram 
1466

1467

2

14488 5

1489

$14 \% 0$ 9
10

1표1

12

$1+432$ 14

$\frac{15}{16} 3$

1474

18

11495

20

21

12426

14 377

$1 \frac{25}{26} 8$

27

12899

29

13180

31

$13+21$

33

13482

13683

13484

39

14185

41

14286

43

14587

1488

48

1489

50

15490

52

$15+91$

54

15592

15493

15994 4

60

61

62

63

64

65

Shah, S.M.I., 1977. Stratigraphy of Pakistan. Geological Survey of Pakistan, Memoir, 12, 138 p.

Shah, Z.U.H., Ahmad, Z., 2015. Hydrochemical mapping of the Upper Thal Doab (Pakistan) using the geographic information system. Environmental Earth Sciences, 74, 2757-2773.

Shah, Z.U.H., Ahmad, Z., 2016. Hydrogeology and hydrochemistry of the Upper Thal Doab (Pakistan). Environmental Earth Sciences, 75(6), 527, doi: 10.1007/s12665-015-5211-z.

Shroder, J.F., Bishop, M.P., 2000. Unroofing of Nanga Parbat Himalaya. In: Khan M.A., Treloar P.J., Searle M.P., Jan M.Q. (Eds.), Tectonics of the Nanga Parbat Syntaxis and the Western Himalaya. Geological Society, London, Special Publication, 170, pp. 163-179.

Singh, G., Wasson, R.J., Agrawal, D.P., 1990. Vegetational and seasonal climatic changes since the last full glacial in the Thar Desert, northwestern India. Review of Palaeobotany and Palynology, 64(1-4), 351-358.

Singh, S., Kumar, R., Barley, M.E., Jain, A.K., 2007. SHRIMP U-Pb ages and depth of emplacement of Ladakh Batholith, Eastern Ladakh, India. Journal of Asian Earth Sciences, 30(34), 490-503.

Singh, S., Jain, A.K., Barley, M.E., 2009. SHRIMP U-Pb c.1860 Ma anorogenic magmatic signatures from the NW Himalaya: implications for Palaeoproterozoic assembly of the Columbia Supercontinent. In: Reddy, S.M., Mazumder, R., Evans, D.A.D., Collins, A.S. (Eds.), Palaeoproterozoic Supercontinents and Global Evolution. Geological Society, London, Special Publications, 323, 283-300.

Singhvi, A. K., Kar, A., 2004. The aeolian sedimentation record of the Thar Desert. Journal of Earth System Science, 113, 371-401.

Singhvi, A.K., Williams, M.A.J., Rajaguru, S.N., Misra, V.N., Chawla, S., Stokes, S., Chauhan, N., Francis, T., Ganjoo, R.K., Humphreys, G.S., 2010. A 200 ka record of climatic change and dune activity in the Thar Desert, India. Quaternary Science Reviews, 29, 3095-3105.

Staubwasser, M., Sirocko, F., Grootes, P.M., Erlenkeuser, H., 2002. South Asian monsoon climate change and radiocarbon in the Arabian Sea during early and middle Holocene. Paleoceanography, 17(4), 1063, doi:10.1029/2000PA000608. 
1495 St-Onge, M.R., Rayner, N., Searle, M.P., 2010. Zircon age determinations for the Ladakh batholith 1496 at Chumathang (Northwest India): Implications for the age of the India-Asia collision in the

Suczek, C.A., Ingersoll, R.V., 1985. Petrology and provenance of Cenozoic sand from the Indus Cone and the Arabian Basin, DSDP sites 221, 222, and 224. Journal of Sedimentary Petrology, 55(3), 340-346.

Tate, E.L., Farquharson, F.K., 2000. Simulating reservoir management under the threat of sedimentation: The case of Tarbela Dam on the River Indus. Water Resources Management, 14 191-208.

Taylor, S.R., McLennan, S.M., 1995. The geochemical evolution of the continental crust. Review of Geophysics, 33, 241-265.

Treloar, P.J., Petterson, M.G., Jan, M.Q., Sullivan, M.A., 1996. A re-evaluation of the stratigraphy and evolution of the Kohistan arc sequence, Pakistan Himalaya: implications for magmatic and tectonic arc-building processes. Journal of the Geological Society London, 153, 681-693.

Vermeesch, P., 2012. On the visualisation of detrital age distributions. Chemical Geology, 312, 190-194.

Vermeesch, P., 2013. Multi-sample comparison of detrital age distributions. Chemical Geology, 341, 140-146.

Vermeesch, P., 2018. Dissimilarity measures in detrital geochronology. Earth-Science Reviews, $178,310-321$.

Vermeesch, P., Garzanti, E., 2015. Making geological sense of 'Big Data' in sedimentary provenance analysis. Chemical Geology, 409, 20-27.

Vermeesch, P., Resentini, A., Garzanti, E., 2016. An R package for statistical provenance analysis. Sedimentary Geology, 336, 14-25.

Vermeesch, P., Rittner, M., Petrou, E., Omma, J., Mattinson, C., Garzanti, E., 2017. High throughput petrochronology and sedimentary provenance analysis by automated phase mapping and LAICPMS. Geochemistry, Geophysics, Geosystems, 18, 4096-4109, doi: 10.1002/2017GC007109. 
1523

$15 \mathrm{R} 4$

1525

4

$15 \frac{5}{6} 6$

1527

1598

10

11

1529

1530

15

$1 \frac{15}{17} 1$

15932

19

13033

21

12534

23

$1 \frac{24}{25} 5$

1356

15897

29

13038

31

32

13339

13540 36

13741

13942

40

1543

42

43

1544

$1 \frac{45}{46}$

4746
48

15947

50

51

15248

53

1549

1550

15751

59

1552

61

62

63

64

65

Von Eynatten, H., Pawlowsky-Glahn, V., Egozcue, J.J., 2002. Understanding perturbation on the simplex: A simple method to better visualize and interpret compositional data in ternary diagrams. Mathematical Geology, 34(3), 249-257.

Weinberg, R.F., Dunlap, W.J., 2000. Growth and deformation of the Ladakh Batholith, Northwest Himalayas: implications for timing of continental collision and origin of calc-alkaline batholiths. The Journal of Geology, 108, 303-320.

Whittington, A., Foster, G., Harris, N., Vance, D., Ayres, M., 1999. Lithostratigraphic correlations in the western Himalaya; an isotopic approach. Geology 27, 585-588.

Whittington, A., Harris, N.B.W., Ayres, M.W., Foster, G., 2000. Tracing the origins of the western Himalaya: an isotopic comparison of the Nanga Parbat massif and Zanskar Himalaya. In: Khan, M.A., Treloar, P.J., Searle, M.P., Jan, M.Q. (Eds.), Tectonics of the Nanga Parbat Syntaxis and the Western Himalaya. Geological Society, London, Special Publications, 170, pp. 201-218.

Yu, Z., Colin, C., Wan, S., Saraswat, R., Song, L., Xu, Z., Clift, P.D., Lu, H., Lyle, M., Kulhanek, D., Hahn, A., Tiwari, M., Mishra, R., Miska, S., Kumar, A., 2019. Sea level-controlled sediment transport to the eastern Arabian Sea over the past 600 kyr: Clay minerals and SrNd isotopic evidence from IODP site U1457. Quaternary Science Reviews, 205, 22-34.

Zeitler, P.K., Chamberlain, C.P., Smith, H.A., 1993. Synchronous anatexis, metamorphism, and rapid denudation at Nanga Parbat (Pakistan Himalaya). Geology, 21, 347-350.

Zeitler, P.K., Meltzer, A.S., Koons, P.O., Craw, D., Hallet, B., Chamberlain, C.P., Kidd, W.S., Park, S.K., Seeber, L., Bishop, M., Shroder, J., 2001. Erosion, Himalayan geodynamics, and the geomorphology of metamorphism. GSA Today, 11, 4-9.

Zhuang, G., Najman, Y., Guillot, S., Roddaz, M., Antoine, P.O., Métais, G., Carter, A., Marivaux, L., Solangi, S.H., 2015. Constraints on the collision and the pre-collision tectonic configuration between India and Asia from detrital geochronology, thermochronology, and geochemistry studies in the lower Indus basin, Pakistan. Earth and Planetary Science Letters, 432, 363-373.

Zhuang, G., Najman, Y., Tian, Y., Carter, A., Gemignani, L., Wijbrans, J., Jan, M.Q., Khan, M.A., 2018. Insights into the evolution of the Hindu Kush-Kohistan-Karakoram from modern river sand detrital geo-and thermochronological studies. Journal of the Geological Society London, 175(6), 934-948. 
1553

1

2

3

4

7

8

10

11

12

13

14

15

16

17

18

19

20

21

22

23

24

25

26

27

28

29

30

31

32

33

34

35

36

37

38

39

40

41

42

43

44

45

46

47

48

49

50

51

52

53

54

55

56

57

58

59

60

61

62

63

64

65 


\title{
Provenance of Thal Desert sand: focused erosion in the western Himalayan syntaxis and foreland-basin deposition driven by latest Quaternary climate change
}

\begin{abstract}
As a latest Pleistocene repository of Indus River sand at the entry point to the Himalayan foreland basin, the Thal dune field in northern Pakistan stores crucial information that can be used to reconstruct the erosional evolution of the Himalayan-Karakorum orogen and the changes in the foreland-basin landscape that took place between the Last Glacial Maximum and the early Holocene. This comprehensive provenance study of Thal Desert sand integrates previously existing petrographic, heavy-mineral, mineral-chemical, isotopic, and geochronological databases with original bulk-sediment geochemistry, zircon-age, and Nd-isotope data. Dune sand is low in quartz and rich in feldspars, volcanic, metavolcanic and metabasite grains, contains a very rich transparent heavy-mineral suite including hypersthene and common zircon grains dated as Late Cretaceous to early Paleogene, and is characterized by high $\mathrm{Mg}, \mathrm{Sc}, \mathrm{V}, \mathrm{Co}, \mathrm{Ni}, \mathrm{Cu}$ concentrations and by $\varepsilon_{\mathrm{Nd}}$ values as high as -3.5 . Together, these data indicate that $\sim 40 \%$ of Thal dune sand was supplied by erosion of the Kohistan arc, a proportion that far exceeds the one assessed for modern Upper Indus sand. Greater detrital supply from the Kohistan arc indicates notably different conditions of sediment generation, during a period in which the sediment-transport capacity of the Upper Indus in the dry lowlands was reduced and volumes of sand were extensively reworked by wind and accumulated in dune fields across the foreland basin. In the early Holocene, the renewed strength of the South Asian monsoon and consequently markedly increased water and sediment discharge led to incision of the Thal and Thar dune fields by the Indus River and its Punjab tributaries draining the Himalayan front directly hit by heavy monsoonal rains.
\end{abstract}




\title{
Provenance of Thal Desert sand: focused erosion in the western \\ Himalayan syntaxis and foreland-basin deposition driven by latest Quaternary climate change
}

\author{
Eduardo Garzanti ${ }^{1 *}$, Wendong Liang ${ }^{1 *}$, Sergio Andò ${ }^{1}$, Peter D. Clift ${ }^{2}$, Alberto \\ Resentini ${ }^{1}$, Pieter Vermeesch ${ }^{3}$, Giovanni Vezzoli ${ }^{1}$. \\ ${ }^{1}$ Laboratory for Provenance Studies, Department of Earth and Environmental Sciences, \\ University of Milano-Bicocca, Milano 20126, Italy \\ ${ }^{2}$ Department of Geology and Geophysics, Louisiana State University, Baton Rouge, LA 70803, \\ USA \\ ${ }^{3}$ London Geochronology Centre, Department of Earth Sciences, University College London, \\ London, C1E 6BT, UK \\ *Corresponding authors (e-mail: eduardo.garzanti@unimib.it and w.liang@ campus.unimib.it)
}

Keywords: Sand petrography and geochemistry; Detrital-zircon geochronology; Variability of ENd values; Focused erosion; Himalaya-Karakorum; Kohistan Arc; Indus River, Delta, and Fan.

\section{Highlights:}

The Thal Desert is an inland archive of Indus sand from the western Himalaya syntaxis

Sand stored in the Thal dunefield reveals major detrital supply from the Kohistan arc

High variability of $\varepsilon_{\mathrm{Nd}}$ values is controlled by minimal changes in monazite content

The Thal Desert formed in a dry landscape between the LGM and the wet early Holocene 


\begin{abstract}
As a latest Pleistocene repository of Indus River sand at the entry point to the Himalayan foreland basin, the Thal dune field in northern Pakistan stores crucial information that can be used to reconstruct the erosional evolution of the Himalayan-Karakorum orogen and the changes in the foreland-basin landscape that took place between the Last Glacial Maximum and the early Holocene. This comprehensive provenance study of Thal Desert sand integrates previously existing petrographic, heavy-mineral, mineral-chemical, isotopic, and geochronological databases with original bulksediment geochemistry, zircon-age, and Nd-isotope data. Dune sand is low in quartz and rich in feldspars, volcanic, metavolcanic and metabasite grains, contains a very rich transparent heavymineral suite including hypersthene and common zircon grains dated as Late Cretaceous to early Paleogene, and is characterized by high $\mathrm{Mg}, \mathrm{Sc}, \mathrm{V}, \mathrm{Co}, \mathrm{Ni}, \mathrm{Cu}$ concentrations and by $\varepsilon_{\mathrm{Nd}}$ values as high as -3.5 . Together, these data indicate that $\sim 40 \%$ of Thal dune sand was supplied by erosion of the Kohistan arc, a proportion that far exceeds the one assessed for modern Upper Indus sand. Greater detrital supply from the Kohistan arc indicates notably different conditions of sediment generation, during a period in which the sediment-transport capacity of the Upper Indus in the dry lowlands was reduced and volumes of sand were extensively reworked by wind and accumulated in dune fields across the foreland basin. In the early Holocene, the renewed strength of the South Asian monsoon and consequently markedly increased water and sediment discharge led to incision of the Thal and Thar dune fields by the Indus River and its Punjab tributaries draining the Himalayan front directly hit by heavy monsoonal rains.
\end{abstract}




\section{Introduction}

The western Himalaya and Karakorum Ranges (in Sanskrit: hima = snow, alayah = abode; in Uyghur Turkic: $k a r a=$ black, korum $=$ gravel) drained by the Indus River provide a spectacular example of an orogenic belt produced by continental collision (Searle, 2013). Ongoing indentation between the Indian and Asian continents since 60-58 Ma (Garzanti et al., 1987; Beck et al., 1995; Hu et al., 2015; Najman et al., 2017) and accelerated rock uplift associated with ultra-rapid exhumation of crystalline basement rocks since the Neogene (Rolland et al., 2001; Zeitler et al., 2001) resulted in extreme relief and erosion rates around the western Himalayan syntaxis (Burbank et al., 1996a; Shroder and Bishop, 2000).

An important contribution to a better understanding of the tectonic growth and erosional evolution of such a complex orogenic region, where geological processes are so intense, is given by provenance analysis of detritus carried by the precursors of the Indus River and stored through time in adjacent sedimentary basins (Critelli et al., 1990; Garzanti et al., 1996; Qayyum et al., 1997; Clift et al., 2001). Numerous studies of Himalayan foreland-basin strata have been devoted to understanding how the Indus River system has formed and evolved (e.g., Cerveny et al., 1989; Critelli and Garzanti, 1994; Najman et al., 2003; Downing and Lindsay 2005; Roddaz et al., 2011; Chirouze et al., 2015; Zhuang et al., 2015). Crucial information is stored in the thick sediment pile accumulated in the Indus Fan, cored so far around its southeastern and western edges during Ocean Drilling Program (ODP) Leg 23 in 1972 (Jipa and Kidd, 1974; Mallik, 1978; Suczek and Ingersoll, 1985) and more recently during International Ocean Discovery Program (IODP) Expedition 355 to the Laxmi Basin in 2014 (Clift et al., 2019). Turbidites of proven Himalayan provenance recovered from both ODP Leg 23 and IODP Expedition 355 are however mostly late Miocene or younger in age, and much thus remains to be understood regarding earlier phases of orogenic erosion (Pandey et al., 1996). 
While plunging deeper in time, paleogeographic reconstructions have to face an increasing number of unknowns, not only because of subsequent accretion and exhumation of diverse geological units but also because repeated modifications of the drainage system have occurred even in the recent past (e.g., Burbank et al., 1996b; Clift et al., 2012). Moreover, the compositional fingerprints of ancient siliciclastic strata reflect a distorted image of the lithological structure of source terranes because of selective diagenetic dissolution of less durable detrital components (Garzanti, 2019a).

The safest way to proceed is to start from the knowledge of the modern sediment-routing system, where everything is in principle known or knowable (Garzanti et al., 2005; Alizai et al., 2011, 2016; East et al., 2015; Zhuang et al., 2018) and to extend that knowledge to the recent and less recent past (Clift et al., 2010; Garzanti et al., 2020). In this regard, a particularly interesting repository of clastic sediments is represented by the Thal Desert, a small dune field occupying a dry area just south of the Salt Range, the Pliocene thrust belt representing the front of the Himalayan orogen in central northern Pakistan (Fig. 1).

Thal Desert dunes consist of wind-reworked sediment entirely supplied by the Indus River upstream of the orogenic front (henceforth named "Upper Indus") that provides us with a precise compositional signature of detritus dominantly generated by the rapid erosion of the western Himalayan syntaxis in the latest Quaternary. The Jhelum River and other large left-bank tributaries draining the southern flank of the Himalaya and flowing across the Punjab plains convey their sediments to the Indus River only downstream of the Thal Desert, and their contribution to this dune field is negligible, as documented by the peculiar compositional signatures of eolian sands (Liang et al., 2019). On the contrary, it is the Thal dunes that, eroded all along the western side of the desert, contribute sand to the Jhelum River and to the Panjnad River downstream (Fig. 2; Garzanti et al., 2005).

The Upper Indus compositional signature preserved in the Thal dune field is exempt from any anthropic modification that had occurred in the region (e.g., Tarbela Dam) and can be compared with sand composition in the Lower Indus River, Delta, and Fan. This allows us to calculate the 
relative amount of sediment shed from diverse upstream sources around the syntaxis versus those derived from the southern side of the Himalaya and/or the Sulaiman-Kirthar Ranges of western Pakistan. By applying the same principle to older deposits, we can explore how erosional patterns have varied through time and reveal how the interplay between tectonic and climatic processes has governed the shift of erosional foci in the past (Clift, 2017; Clift et al., 2019).

The aim of the present study is to document in detail the diverse compositional fingerprints of Thal Desert sand by applying multiple analytical techniques, including high-resolution bulk-sediment petrography and geochemistry, heavy minerals and heavy-mineral chemistry, detrital-zircongeochronology, and $\mathrm{Nd}$ isotopes. This integrated dataset is employed to discuss the erosional evolution of the western Himalaya and the sedimentary evolution of the Indus River, Delta and Fan through the latest Cenozoic.

\section{The Thal Desert}

Pakistan is an arid to semi-arid subtropical country including the large Thar Desert $\left(\sim 175,000 \mathrm{~km}^{2}\right)$ straddling the political border with India in the southeast (Singh et al., 1990; Enzel et al., 1999; Singhvi and Kar, 2004; Singhvi et al., 2010; East et al., 2015). In the north, the much smaller and much less well studied, $300 \mathrm{~km}$-long and $100 \mathrm{~km}$-wide Thal Desert is located between about $30^{\circ}$ and $32^{\circ} 30^{\prime} \mathrm{N}$ and between about $71^{\circ}$ and $72^{\circ} \mathrm{E}$ (Fig. 1). This triangular-shaped desert occupies the Thal or Sind-Sagar Doab (in Farsi: $d o a b=$ two waters, or land between two adjacent rivers), the region extending between the course of the Indus River in the west and the Punjab plain in the east, built by the Jhelum, Chenab, Ravi, and Beas-Sutlej Rivers (in Farsi: punj $a b=$ five waters, or land of the five rivers).

The Thal Desert, located between the Indus and Jhelum Rivers, is delimited by the Salt Range foothills in the north, whereas the Indus floodplain is bounded by the Sulaiman Range in the west. Exposed in the Salt Range are Neoproterozoic evaporites overlain by a fossiliferous Cambrian to Cenozoic succession (Shah, 1977). The Sulaiman fold-thrust belt includes largely shelfal upper 
Paleozoic to Eocene strata, Neogene molasse, and deep-water turbidites underlain by ophiolitic complexes (Jadoon et al., 1994). The Punjab plains are underlain by up to $450 \mathrm{~m}$ of Quaternary alluvium and eolian deposits lying over semiconsolidated Cenozoic rocks or directly over Precambrian crystalline basement, which crops out in the Kirana Hills straddling the Chenab River course and represents the topographic culmination of the NW/SE-trending Delhi-Sargodha ridge (Greenman et al., 1967; Kadri, 1995).

\subsection{Geomorphology}

Different physiographic units can be distinguished in the Thal Desert, which lies at altitudes above sea-level decreasing from $\sim 200 \mathrm{~m}$ in the north to $\sim 120 \mathrm{~m}$ in the south. The piedmont area transitional to the Salt Range foothills hosts alluvial fans consisting of detritus reworked and deposited during sheet floods, and fining downstream over distances of $\sim 10 \mathrm{~km}$. The desert area to the south, covered by low sand dunes or rolling sand plains alternating with narrow valleys of cultivable land, is underlain by Quaternary fluvial and eolian deposits more than 350 m-thick in southern areas, but even thicker in the central part of the desert (Nickson et al., 2005). The recent finding of Mesolithic artefacts at the top of sand dunes indicates that the accumulation of eolian sand pre-dates the Holocene (Biagi et al., 2019). The last episode of dune growth may thus be related to large sediment fluxes released during glacier retreat following the Last Glacial Maximum (LGM) in the latest Pleistocene (Clift and Giosan, 2014).

The underlying alluvium mostly consists of laterally continuous bodies of fine to coarse sand, with minor gravel and isolated mud lenses. Coarser deposits occur in the north closer to the Salt Range, but otherwise the distribution of grain sizes is irregular, largely reflecting original deposition by the constantly shifting paleo-Indus and/or adjacent tributaries. The presently active Indus River floodplain reaches $>20 \mathrm{~km}$ in width in the south. The abandoned floodplain is even wider and includes areas of higher ground. These bar uplands are actively eroded by the Jhelum River in the 
105

northeastern part of the desert, forming up to $10 \mathrm{~m}$-high scarps facing the floodplain (Greenman et al., 1967).

\subsection{Climate}

Summers are very hot in the Thal Desert with average temperatures around $35^{\circ} \mathrm{C}$ in June to July, dropping to $\sim 10^{\circ} \mathrm{C}$ in December to January. Average annual temperatures increase from $\sim 24^{\circ} \mathrm{C}$ in the north and west to $\sim 28^{\circ} \mathrm{C}$ in the south. Most of the region receives less than $350 \mathrm{~mm}$ of rain per year. Annual rainfall progressively decreases from the northern $(617 \mathrm{~mm}$ on average recorded from 1991 to 2013 in the Mianwali meteorological station; Shah and Ahmad, 2015) to the southern edges of the desert (150 mm; Greenman et al., 1967). Today, cold dry winds blow from the north in winter, whereas hot rain-bearing winds blow from the south in summer, with an average speed of several km per hour. Between March and April, hailstorms generated by air turbulence owing to the high temperature difference between the warm surface and the cold upper atmosphere may cause major damage to crop and buildings (Gosal, 2004). In the summer, dust storms are fostered by unsteady thermal conditions and north/south temperature gradients (Hussain et al., 2005).

\subsection{Sediment flux}

The upper course of the Indus River, sourced in the Tibetan Plateau (Fig. 2), drains the Ladakh arc and forearc basin together with the northern side of the Himalaya (Garzanti and Van Haver, 1988; Henderson et al., 2010; Munack et al., 2014). Next, it cuts a deep gorge through the Nanga Parbat crystalline massif and receives detritus from the Karakorum Range and Kohistan Arc (Gaetani et al., 1990; Treloar et al., 1996; Searle et al., 1999; DiPietro and Pogue, 2004; Pêcher et al., 2008; Burg, 2011). Further downstream, it flows across the Himalayan belt and Potwar Plateau (Khan et al., 1997a), where it joins with the Kabul River draining the Hindukush Range (Hildebrand et al., 2001), crosses the Salt Range to eventually reach the lowlands where it flows southward confined between the front of the Sulaiman Range in the west and the Thal Desert in the east (Fig. 1). After closure of the Chashma Dam at the northwestern corner of the Thal Desert in 1971, and of the 
134 Tarbela Dam $200 \mathrm{~km}$ to the north in 1976, most of the sediment carried by the Indus River has $\frac{1}{25}$ been trapped in artificial reservoirs. The suspended sediment flux upstream of Tarbela Dam was

3 136 5 $1 \frac{6}{7} 7$ 8 198 10 gauged as between 176-200 $\cdot 10^{6}$ t/a (Tate and Farquharson, 2000; Ali and De Boer, 2007, 2008) and 218,235 , or $287 \cdot 10^{6}$ t/a (Rehman et al., 1997), whereas estimates of total sediment delivery to the Arabian Sea before the Anthropocene range widely between $100 \cdot 10^{6} \mathrm{t} / \mathrm{a}$ and $675 \cdot 10^{6} \mathrm{t} / \mathrm{a}$ (Ali and De Boer, 2007). Suspended load of the Kabul River was measured as $36.6 \cdot 10^{6}$ t/a (i.e. $17 \pm 3 \%$ that of the Indus upstream of Tarbela Dam; Rehman et al., 1997)

The Thal Doab aquifer, consisting of Quaternary alluvial and eolian deposits with local mud lenses, is recharged rapidly from river water and rainfall. The Indus River and its Punjab tributaries give rise to one of the largest irrigation systems in the world, including the Chashma-Jhelum link canal supplied with Indus waters and built between 1967 and 1971. A network of dams, barrages and canals aims to convert the Thal Desert, where the water table lies between 9 and $0.5 \mathrm{~m}$ from ground surface, into cultivable land (Shah and Ahmad, 2016; Hussain et al., 2017).

The main tributaries joining the Indus River downstream of the Thal Desert drain the Himalayan belt (Fig. 2). Since the 1960 Indus Waters Treaty gave rights to the entire flow of the Indus, Jhelum, and Chenab Rivers to Pakistan, and of the Ravi, Beas, and Sutlej Rivers to India, all Himalayan tributaries of the Punjab have been dammed and linked by canals to irrigate the arid plains and compensate for lost waters in eastern Pakistan. Water discharge dropped sharply from $\geq 100 \mathrm{~km}^{3} / \mathrm{a}$ to $\leq 60 \mathrm{~km}^{3} / \mathrm{a}$, and flow in the Ravi and Sutlej Rivers ceased except during monsoon floods. The Mangla Dam, completed in 1967, has reduced sediment load of the Jhelum River from $45 \cdot 10^{6}$ t/a to $<0.5 \cdot 10^{6}$ t/a (Milliman et al., 1984; Meadows and Meadows, 1999; Giosan et al., 2006a). The main right-bank (western) tributaries of the Indus River draining the Sulaiman Ranges are the Gomal River (basin area 36,000 $\mathrm{km}^{2}$ ), characterized by extreme concentration of suspended solids (42 g/l) and high sediment load (30 $\left.10^{6} \mathrm{t} / \mathrm{a}\right)$, and the Kurram River $\left(3 \cdot 10^{6} \mathrm{t} / \mathrm{a}\right.$; Rehman et al., 1997). Other rivers are minor and mostly flow during flash floods.

\section{Methods}


162 This study, focusing on fine-grained sand of eolian dunes sampled in February 2001 from the Thal

Desert, provides geochemical and geochronological data on sand collected between 2001 and 2011

\subsection{Sand petrography and heavy minerals}

A quartered aliquot of each bulk-sand sample of Thal Desert dunes was impregnated with araldite epoxy, cut into a standard thin section stained with alizarine red to distinguish dolomite and calcite, and analysed by counting 400 points by the Gazzi-Dickinson method (Ingersoll et al., 1984). Sand classification was based on the relative abundance of the three main groups of components $(\mathrm{Q}=$ quartz; F = feldspars; $\mathrm{L}=$ lithic fragments), considered where exceeding 10\%QFL. According to standard use, the less abundant component goes first, the more abundant last (e.g., in a lithofeldspatho-quartzose sand Q > F > L > 10\%QFL; Garzanti, 2019b). Metamorphic grains were classified by protolith composition and metamorphic rank; average rank of rock fragments in each sample was expressed by the metamorphic indices $\mathrm{MI}$ and $\mathrm{MI}^{*}$, ranging respectively from 0 (detritus from sedimentary and volcanic rocks) or 100 (detritus from very low-grade metamorphic rocks) to 500 (detritus from high-grade metamorphic rocks; Garzanti and Vezzoli, 2003). Median grain size was determined in thin section by ranking the samples from coarsest to finest followed by visual comparison with in-house standards sieved at $0.25 \phi$ interval. 
187 Heavy minerals were separated in sodium polytungstate (density $\sim 2.90 \mathrm{~g} / \mathrm{cm}^{3}$ ), using the $63-250 \mu \mathrm{m}$ $\frac{1}{188}$ fraction obtained by sieving and treated with oxalic and acetic acids. Analyses were carried out first

3 189 5 190 8 $19) 1$ 10

by counting 200-225 transparent heavy minerals on grain mounts by the area method (Mange and Maurer, 1992). Next, in order to obtain an accurate estimate of volume percentages of each dense detrital component (Galehouse, 1971), between 275 and 1300 dense grains per sample (700 on average) were point-counted on a polished thin section by semi-automated analysis with a Raman spectrometer (Andò and Garzanti, 2014; Lünsdorf et al., 2019).

Transparent heavy-mineral assemblages, called for brevity "tHM suites" throughout the text, are defined as the spectrum of detrital extrabasinal minerals with density $>2.90 \mathrm{~g} / \mathrm{cm}^{3}$ identifiable under a transmitted-light microscope. According to the volume percentage of transparent heavy minerals in the sample (tHMC), tHM suites are defined as "poor" (tHMC $<1)$, "moderately poor" $(1 \leq$ tHMC < 2), "moderately rich" $(2 \leq \mathrm{tHMC}<5)$, "rich" $(5 \leq \mathrm{tHMC}<10)$, "very-rich" $(10 \leq \mathrm{tHMC}<$ 20), or "extremely rich" (20 < tHMC < 50) (Garzanti and Andò, 2007, 2019). The sum of zircon, tourmaline and rutile over total transparent heavy minerals (ZTR index of Hubert, 1962) estimates the durability of the tHM suite (i.e., extent of recycling; Garzanti, 2017). Detrital components are listed in order of abundance (high to low) throughout the text. The complete petrographic and heavy-mineral datasets are provided in Appendix Tables A2, A3, A4, and A5. Further information on the chemical composition of detrital amphiboles, garnets, epidote-group minerals, and pyroxenes is provided in Liang et al. (2019).

\subsection{U-Pb zircon geochronology}

Detrital zircons were identified by Automated Phase Mapping (Vermeesch et al., 2017) with a Renishaw inVia ${ }^{\mathrm{TM}}$ Raman microscope on the heavy-mineral separates of 14 samples (three from the Thal Desert, two from the Upper Indus, and nine from diverse end-member sources). U-Pb zircon ages were determined at the London Geochronology Centre using an Agilent 7700x LA-ICP-MS (laser ablation-inductively coupled plasma-mass spectrometry) system, employing a NewWave 
214 NWR193 Excimer Laser operated at $10 \mathrm{~Hz}$ with a $20 \mu \mathrm{m}$ spot size and $\sim 2.5 \mathrm{~J} / \mathrm{cm}^{2}$ fluence. No

cathodo-luminescence imaging was done, and the laser spot was always placed "blindly" in the middle of zircon grains in order to treat all samples equally and avoid bias in intersample comparison ("blind-dating approach" as discussed in Garzanti et al., 2018). Data reduction was performed using GLITTER 4.4.2 software (Griffin et al., 2008). We used ${ }^{206} \mathrm{~Pb} /{ }^{238} \mathrm{U}$ and ${ }^{207} \mathrm{~Pb} /{ }^{206} \mathrm{~Pb}$ ages for zircons younger and older than $1100 \mathrm{Ma}$, respectively. No common $\mathrm{Pb}$ correction was applied. Grains with $>+5 /-15 \%$ age discordance were discarded, and 1392 concordant ages were obtained overall. The full geochronological dataset is provided in Appendix B.

\subsection{Bulk chemistry and Nd isotopes}

Chemical analyses of 23 sand samples (four from the Thal Desert, eight from diverse end-member sources, three from the Upper Indus, four from Punjab tributaries, and four from the Lower Indus and Delta) were carried out at Bureau Veritas Mineral Laboratories (Vancouver) on a split aliquot of the 63-2000 $\mu \mathrm{m}$ fraction obtained by wet sieving. Major oxides were determined by ICP-ES and trace elements by ICP-MS, following a lithium metaborate/tetraborate fusion and nitric acid digestion. A separate split was digested in aqua regia and analysed for $\mathrm{Mo}, \mathrm{Cu}, \mathrm{Ag}, \mathrm{Au}, \mathrm{Zn}, \mathrm{Cd}, \mathrm{Hg}$, $\mathrm{Tl}, \mathrm{Pb}, \mathrm{As}, \mathrm{Sb}, \mathrm{Bi}$ and $\mathrm{Se}$, but the concentration of these elements is generally underestimated because of incomplete leaching of refractory minerals. For further information on adopted procedures, geostandards used, and precision for various elements see http://acmelab.com (code LF200). The geochemical dataset is provided in Appendix Table A6.

For each of the four Thal Desert samples, several grams of the bulk sand were powdered to ensure a good average composition. Samples were then dissolved, and the Nd separated using standard column extraction techniques. $\mathrm{Nd}$ isotopic compositions were determined on VG354 mass spectrometer at Woods Hole Oceanographic Institution. ${ }^{143} \mathrm{Nd} /{ }^{144} \mathrm{Nd}$ values were normalized to ${ }^{146} \mathrm{Nd} /{ }^{144} \mathrm{Nd}=0.7219$ and relative to 0.511847 for the La Jolla standard. We calculated the parameter $\varepsilon_{\mathrm{Nd}}$ (DePaolo and Wasserburg, 1976) using a ${ }^{143} \mathrm{Nd} /{ }^{144} \mathrm{Nd}$ value of 0.512638 for the Chondritic 
241 Uniform Reservoir (Hamilton et al., 1983). Original data and a compilation of literature data are provided in Appendix Tables A7 and A8.

\subsection{Statistical/graphical displays}

Zircon-age data, plotted using the provenance package of Vermeesch et al. (2016), are visualized as kernel density estimates (KDE) with a nominal bandwidth of 40 Ma (Vermeesch, 2012). Statistical techniques used to illustrate our datasets also include the compositional biplot (Gabriel, 1971) and multidimensional scaling (MDS; Vermeesch, 2013; Vermeesch and Garzanti, 2015).

The biplot, drawn using CoDaPack software by Comas-Cufí and Thió-Henestrosa (2011), allows discrimination among multivariate observations (points) while shedding light on the mutual relationships among variables (rays). The length of each ray is proportional to the variance of the corresponding variable in the dataset. If the angle between two rays is close to $0^{\circ}, 90^{\circ}$ or $180^{\circ}$, then the corresponding variables are directly correlated, uncorrelated, or inversely correlated, respectively.

MDS produces a map of points in which the distance among samples is approximately proportional to the Kolmogorov-Smirnov dissimilarity of their compositional or chronological signatures. Closest and second-closest neighbours are linked by solid and dashed lines, respectively, and the goodness of fit is evaluated using the "stress" value of the configuration $(0.2=$ poor; $0.1=$ fair; $0.05=$ good; Kruskal, 1964; table 1 in Vermeesch, 2013; 2018).

\section{Compositional fingerprints of Thal Desert sand}

\subsection{Petrography and heavy minerals}

Three Thal dune samples are litho-feldspatho-quartzose sands and one is quartzo-feldspatho-lithic (average composition Q37 F34 L29; Fig. 3A). Quartz is mostly monocrystalline. K-feldspar and plagioclase occur in subequal amounts. The rock-fragment population includes metasedimentary (paragneiss, schist, slate, calcschist, phyllite, metasandstone), metabasite (prasinite, chloritoschist, 
amphibolite), carbonate (limestone, dolostone), other sedimentary (shale, siltstone, minor chert), granitoid, felsic to mafic volcanic and metavolcanic, and minor ultramafic (serpentineschist, cellular serpentinite) grains (MI 209-290, MI* 273-317). A few muscovite and biotite flakes are present. The very rich tHM suite is dominated by mainly blue-green amphiboles associated with epidote, garnet, green to colourless clinopyroxene, and hypersthene. Titanite, staurolite, kyanite, zircon, tourmaline, rutile, sillimanite, olivine, and chloritoid also occur $($ ZTR $\leq 4)$. Detrital amphiboles include mainly hornblende, subordinate pargasite, actinolite, hastingsite, and minor tschermakite. Detrital garnet is mostly almandine with minor grossular, pyrope, spessartine, and andradite (mostly Bi grains with minor $\mathrm{Ci}, \mathrm{Bii}, \mathrm{A}$, and a few $\mathrm{D}$ grains according to the classification of Mange and Morton, 2007). Epidote-group minerals are mainly clinozoisite and epidote. Detrital pyroxene is mainly diopside with common orthopyroxene and minor augite (Liang et al., 2019).

\subsection{Detrital-zircon geochronology}

The three Thal samples analysed yielded 103 concordant ages overall, including early Miocene (22 Ma; n=3), Eocene (38-53 Ma; n=15), latest Cretaceous/Paleocene (61-84 Ma; n=19), midCretaceous (98-110 Ma; n=10), Orosirian (1.82-1.87 Ga; n=15), and earliest Paleoproterozoic clusters (2.32-2.39 Ga; $n=4)$. Other ages are spread in the Mesozoic $(n=6)$, Paleozoic $(n=6)$, Neoproterozoic $(n=13)$, late Mesoproterozoic $(n=4)$, Paleoproterozoic $(n=4)$, and earliest Paleoproterozoic to late Neoarchean $(n=4)$.

\subsection{Sand geochemistry}

Despite their homogenous provenance, local selective-entrainment effects account for a difference in heavy-mineral concentration by a factor of two in our Thal Desert sand samples. This corresponds to a difference by factors of between 2.5 and 5 of elements preferentially hosted in the densest rock-forming minerals such as opaque Fe-Ti-Cr oxides, monazite, zircon, and to a lesser extent rutile and garnet (i.e., Fe, Ti, Mn, Y, REE, Th, U, Zr, Hf, V, Nb, Ta and Cr). The europium anomaly $\mathrm{Eu} / \mathrm{Eu}^{*}$ varies from 0.74 in the less heavy-mineral rich sample S1474 (Zr $106 \mathrm{ppm}$ ) to 0.46 
299 in the sample richest in heavy minerals $\mathrm{S} 1470$ (Zr $524 \mathrm{ppm}$ ) and is 0.62-0.64 in the other two

samples S1462 and S1463 (Zr 195-213 ppm). The composition of Thal Desert sand compares remarkably well with the Upper Continental Crust standard (UCC; Taylor and McLennan, 1995; Rudnick and Gao, 2003), but with twice as much Th and $\mathrm{Cr}, \sim 50 \%$ more $\mathrm{Ca}, \mathrm{Y}, \mathrm{REE}$, and $\mathrm{Zr}$, and $\sim 50 \%$ less $\mathrm{K}, \mathrm{Rb}$, and $\mathrm{Ba}$, differences all largely accounted for by the strong local concentration of densest minerals by selective-entrainment effects.

\subsection{Nd isotopes}

Neodymium isotope ratios range widely in the studied Thal Desert sand samples. All four samples are fine sands, but coarser samples characterized by higher heavy-mineral concentration and more volcanic, metavolcanic, and metabasite rock fragments have less negative $\varepsilon_{\mathrm{Nd}}(2.0-2.2 \phi$; tHMC 18$19 ; \varepsilon_{\mathrm{Nd}}-3.5$ and -8.7$)$ than finer-grained samples (2.3-2.7 $\phi ;$ tHMC 10-15; $\varepsilon_{\mathrm{Nd}}-10.9$ and -13.2$)$. Because their bulk-sediment mineralogy is homogeneous overall, indicating notably constant provenance, such a marked variability is dominantly controlled by local factors including grain size and concentration of densest minerals by selective entrainment of less dense grains by wind deflation.

\section{Compositional fingerprints of sand sources}

All geological domains drained by the Upper Indus, including the Ladakh and Kohistan arcs, the Karakorum and Hindukush Ranges, the Himalayan belt, and the Nanga Parbat massif are detrital sources of Thal Desert dunes (Fig. 4). The mineralogical signatures of modern sand carried by tributaries draining each geological domain, summarized here below, are illustrated in detail in Garzanti et al. (2005) and Liang et al. (2019).

\subsection{Petrography and heavy minerals}


Indus tributaries draining the Ladakh arc carry quartzo-feldspathic to feldspar-rich feldspathoquartzose plutoniclastic sand with a rich to very rich tHM suite dominated by amphibole (mostly hornblende), with minor epidote, titanite, apatite, and clinopyroxene (mainly diopside). Hypersthene or allanite are found locally.

River sand from the Kohistan arc ranges in composition from feldspatho-quartzo-lithic to lithoquartzo-feldspathic metamorphiclastic with common prasinite and epidote-amphibolite grains and a very rich to extremely rich tHM suite dominated by amphibole (mainly hornblende or pargasite associated with actinolite or hastingsite and rare tschermakite). Epidote-group minerals (mostly clinozoisite) and pyroxene (diopside, pigeonite, augite, and hypersthene) are common, whereas mostly Ca-rich or Mg-rich garnet is rare.

Indus tributaries draining the Karakorum carry sand ranging in composition from quartzofeldspatho-lithic sedimentaclastic (North Karakorum) to quartzo-feldspathic plutoniclastic (Central Karakorum) or litho-feldspatho-quartzose metamorphiclastic with marble grains (South Karakorum). Mainly moderately rich tHM suites include mostly amphibole (mainly hornblende with pargasite, hastingstite, or actinolite), epidote-group minerals (epidote, clinozoisite, and allanite), mostly Bi-type garnet, titanite, mostly diopsidic clinopyroxene, and minor kyanite, staurolite and sillimanite. A similar composition characterizes feldspatho-quartzo-lithic sedimentaclastic sand of the Kabul River upstream of the Swat confluence.

Detritus from the Greater Himalaya, contributed by the Zanskar River and by minor rivers in northern Pakistan, is litho-feldspatho-quartzose metamorphiclastic with a moderately rich tHM suite including amphibole (pargasite and hornblende with minor hastingsite), mostly Bi-type garnet, fibrolitic sillimanite, kyanite, epidote-group minerals (epidote, clinozoisite, minor allanite), and pyroxene (diopside, augite, and locally hypersthene).

Sand supplied by tributaries draining the Nanga Parbat massif is mainly feldspar-rich feldspathoquartzose with an up to very rich tHM suite dominated by amphibole (mainly hornblende with 
352 common tschermakite and minor pargasite). Garnet (mainly $\mathrm{Ci}$ and minor Bii types), pyroxene $\frac{1}{25} 3$ (diopside with rare augite), epidote, clinozoisite, and sillimanite occur.

3 354 5

The Soan River, mostly recycling Cenozoic foreland-basin strata, carries feldspatho-litho-quartzose sedimentaclastic sand with a moderately rich, epidote-dominated tHM suite with garnet, hornblende, and tourmaline.

As far as REE-rich minerals are concerned, allanite is invariably common (2-3 tHM\%) in sand carried by the Hushe, Braldu, Hispar, and Hunza Rivers draining the Karakorum Range. Karakorum-derived sand contains two to five times more allanite than sand shed by the Greater Himalaya and Nanga Parbat, and one order of magnitude more allanite than sand shed by the Ladakh and Kohistan arcs. Monazite is rarer and was detected in sand derived from the Karakorum and in Zanskar sand.

\subsection{Detrital-zircon geochronology}

\subsubsection{Ladakh and Kohistan arcs}

Modern river sand derived from the Transhimalayan arcs yielded simple zircon-age spectra (Fig. 5), reflecting peaks of magmatic activity in the Ladakh (50-70 Ma, Weinberg and Dunlap, 2000; 58-60 Ma, Singh et al., 2007; 50-67 Ma, Ravikant et al., 2009; 47-58 Ma, St-Onge et al., 2010) and Kohistan arc (82-99 Ma, Schaltegger et al., 2002; 42-85 Ma, Jagoutz et al., 2009).

Sand of the Domkar stream draining the Ladakh arc shows a dominant Eocene-Paleocene peak (49$65 \mathrm{Ma} ; \mathrm{n}=34)$ with a younger age at $46 \mathrm{Ma}$ and a Late Cretaceous cluster (78-87 Ma; n=7). Kandia and Swat sands derived from the Kohistan arc display a Late Cretaceous peak (73-95 Ma; $\mathrm{n}=54$ ) with two younger ages at $56 \mathrm{Ma}$ and $69 \mathrm{Ma}$ and three older ages at $716 \mathrm{Ma}, 1086 \mathrm{Ma}$, and $2545 \mathrm{Ma}$. A younger spectrum, very similar to Domkar sand, was obtained by Zhuang et al. (2018) from Dir River sand, which displays a prominent Eocene-Paleocene peak (43-65 Ma; n=76), several Cretaceous aged grains (76-118 Ma; $n=14)$, and a few older grains (196-821 Ma; $n=4)$.

\subsubsection{Karakorum Range}


The four samples of Karakorum river sand yielded 576 concordant ages overall (Fig. 5), including prominent peaks in the early Miocene/latest Oligocene (16-26 Ma; n=19), late Eocene (35-43 Ma; $\mathrm{n}=51$ ), Paleocene (57-66 Ma; $n=10)$, and mid-Cretaceous (99-130 Ma; $n=184$ ), with sparse ages in the Rupelian (31 Ma), early Eocene (48 Ma), Campanian (73 Ma and $76 \mathrm{Ma}$ ), and Turonian (91-92 Ma; $n=4)$. Older ages are irregularly spread between the earliest Cretaceous and the Ordovician (134-484 Ma; $\mathrm{n}=47$ ), form a broad cluster ranging between the Cambrian and the latest Mesoproterozoic (490-1026 Ma; n=201), are again sparsely spread through the Mesoproterozoic and Paleoproterozoic (1050-2448 Ma; n=34), and form a cluster straddling the Proterozoic/Archean boundary (2468-2535 Ma; n=15) with a few older Archean grains (2553-3568 Ma; n=7). Most ages from our Upper Hunza River sample combined with that from the same site analysed by Zhuang et al. (2018) outline two dominant young clusters at 48-74 Ma (n=51) and 101-122 Ma (n=81) with other sparse ages at $44 \mathrm{Ma}, 82-93 \mathrm{Ma}(\mathrm{n}=4), 126-130 \mathrm{Ma}(\mathrm{n}=3)$, and $239 \mathrm{Ma}$. All older ages (377$893 \mathrm{Ma} ; \mathrm{n}=7$ ) are from our sample.

Zircon ages in Karakorum-derived sand correspond closely with the ages of igneous and metamorphic rocks exposed in the range. The early Miocene peak found in zircons from Hushe (19$26 \mathrm{Ma} ; \mathrm{n}=9 / 55)$ and Braldu (16-25 Ma; $\mathrm{n}=10 / 124)$ sands reflects the age of high-grade metamporphism, crustal melting and emplacement of the Baltoro granite (21-26 Ma; Schärer, et al., 1990; 13-26 Ma, Searle et al., 2010; 15-26 Ma, Mahar et al., 2014). The Eocene peak found in Hispar sand (35-42 Ma; $n=48 / 359)$ reflects the age of upper-amphibolite-facies metamorphism in the South Karakorum belt (44-64 Ma, Fraser et al., 2001; 37-55 Ma, Rolland et al., 2001). The Lower Cretaceous peak is prominent in all samples (100-125 Ma; $n=120 / 359$ in Hispar sand, $\mathrm{n}=29 / 124$ in Braldu sand, and $\mathrm{n}=15 / 55$ in Hushe sand) and reflects the emplacement age of the central Karakorum batholith (95-110 Ma, Debon et al., 1987; 95-115 Ma, Crawford and Searle, 1992). Whereas earliest Cretaceous to Silurian zircons are few and possibly recycled from sedimentary and low-grade metasedimentary rocks, ages between the Ordovician and the latest Mesoproterozoic are common in all samples, and reflect the Pan-African orogenic event widely 
408

4) 9

3

410

5

491

482

4913

1994

11

得

14

1456

16

47
18

19

2018

21

24 9

detected in the Himalayas (Garzanti et al., 1986; DeCelles et al., 2000; Miller et al., 2001; Gehrels et al., 2003). Older zircons, mostly represented in Hispar and Braldu sands with ages clustering around $2.5 \mathrm{Ga}$, may be largely recycled from sedimentary and metasedimentary units.

\subsubsection{Hindukush Range and Kabul River}

In a sand sample analysed by Zhuang et al. (2018) from the Chitral-Kunar River, which drains both Hindukush and Karakorum Ranges, half of the zircon ages are spread between the Cambrian and the Tonian (486-976 Ma; $\mathrm{n}=61 / 126)$, whereas minor clusters are documented at $62-70 \mathrm{Ma}(\mathrm{n}=8)$, 102-114 Ma (n=16), 1851-1891 Ma (n=6), and 2467-2515 Ma (n=4).

The zircon age-spectrum obtained by Zhuang et al. (2018) on a sand sample from the Kabul River downstream is notably different, with a younger peak at 31-38 Ma $(\mathrm{n}=12)$, a Cretaceous cluster at 75-113 Ma (n=39), a small peak at 191-204 Ma $(n=10)$ - a Cimmerian age characteristic of Hindukush igneous and metamorphic rocks (Hildebrand et al., 2001) -, a broad Cambrian-Tonian spread (495-986 Ma; n=28), and a few Orosirian (1841-1847 Ma; n=3) and older ages (2074-2592 Ma; $n=7)$. Ages were recorded also at 46-71 Ma (n=3), 123-179 Ma (n=7), 211-482 Ma (n=7), and $1011-1419 \mathrm{Ma}(\mathrm{n}=4)$.

\subsubsection{Nanga Parbat}

The Astor River sand derived from the Nanga Parbat massif yielded a unimodal earliest StatherianOrosirian peak at $1787-1941 \mathrm{Ma}(\mathrm{n}=98)$ consistent with the age of the gneissic basement $(\sim 1850$ Ma; Zeitler et al., 1993; Whittington et al., 2000; Schneider et al., 2001). This major episode of crustal growth is widely recognized in the Lesser Himalaya (e.g., Miller et al., 2000; Singh et al., 2009; Gehrels et al., 2011; “Ulleri-Wangtu” event of Prasad et al., 2011). Older Paleoproterozoic ages (1964-2494 Ma; n=14) and one latest Carboniferous age also occur (Fig. 5). No grain younger than $47 \mathrm{Ma}$ was found, and the few early Eocene to Late Cretaceous zircons (47-88 Ma; n=7) may be derived from the Ladakh arc drained in the upper course.

\subsubsection{Greater Himalaya}


Nandihar River sand derived from the Greater Himalaya in Pakistan yielded mainly early-middle Neoproterozoic ages (740-989 Ma; n=20), with sparse Carboniferous to Ediacaran ages (345-547 $\mathrm{Ma} ; \mathrm{n}=11)$ and a few younger (105 Ma and $216 \mathrm{Ma}$ ) and older grains (1700 Ma, $1803 \mathrm{Ma}$, and 2400 Ma) (Fig. 5). A similar spectrum was obtained by Jonell et al. (2017a) from Zanskar River sand, with better defined Cryogenian-Tonian (751-856 Ma; $\mathrm{n}=44)$ and Carboniferous-Ordovician clusters (337-476 Ma; n=27), and sparse younger (58 Ma, $246 \mathrm{Ma}$, and $301 \mathrm{Ma}$ ) and older ages (1040-3117 $\mathrm{Ma} ; \mathrm{n}=17)$

\subsection{Sand geochemistry}

The provenance-discrimination power of bulk-sediment geochemistry is limited, because the same chemical elements are hosted in different minerals found in a wide range of rocks and because element concentrations are severely affected by grain-size and hydraulic-sorting effects (Garzanti, 2016). Nevertheless, some remarkable differences are noted among sands derived from different geological domains surrounding the western Himalayan syntaxis (Fig. 6A).

Sand derived from the Kohistan arc is enriched 1.5-2 times in $\mathrm{Fe}, \mathrm{Mg}, \mathrm{Ca}, \mathrm{Sc}, \mathrm{Ti}, \mathrm{V}$ and $\mathrm{Cr}$ relatively to the UCC standard, and depleted by $\sim 50 \%$ or more in $\mathrm{K}, \mathrm{Rb}, \mathrm{Ba}, \mathrm{LREE}, \mathrm{Th}, \mathrm{U}, \mathrm{Zr}, \mathrm{Hf}$, $\mathrm{Nb}$, Ta and Sn, reflecting the mainly intermediate to mafic character of calc-alkaline magmatic source-rocks. Domkar sand derived from the Ladakh arc is notably different and much closer to the UCC standard, although depleted by $50 \%$ or more in $\mathrm{Mg}, \mathrm{Nb}, \mathrm{Ta}, \mathrm{Cr}$ and $\mathrm{Co}$, which reflects the more felsic character of the largely granodioritic calc-alkaline source rocks.

Hispar River sand derived from the Central and South Karakorum is enriched by factors of 2-3 relative to the UCC standard in REE, U, Zr and Hf, and by factors of 5-10 in Th, W and As. This may be ascribed to selective entrainment of less dense detrital components in the river channel and consequent concentration of densest minerals probably including monazite and scheelite. Elements most depleted relative to the UCC are $\mathrm{Mg}, \mathrm{V}$, Co and Ni. 
465 Himalayan-derived sand displays overall homogeneous character. Most elements - excepting Si,

$\frac{1}{466}$ 3 467 5 6
468 8 469 10

170 13 147 1 15

162 18 $149 / 3$ 20

274 23 245 25

246 27
287 $249 / 8$ 3099 32 $3+80$ 34 3581

Ca, LREE and Th - are slightly depleted relatively to the UCC standard, which is typical of sand including detritus recycled from sedimentary and metasedimentary rocks. Large differences in Ca and to a lesser extent $\mathrm{Sr}$ reflect varying amounts of carbonate detritus, which is particularly abundant in sand of the Zanskar River cutting across the Tethys Himalaya zone (Blöthe et al., 2014; Jonell et al., 2017a). Zanskar and Astor sands are the closest to UCC composition: Zanskar sand is markedly depleted in V, Cr, Co and $\mathrm{Ni}$, and Astor sand slight enriched in $\mathrm{Rb}$ and $\mathrm{Th}$ and markedly depleted in $\mathrm{Nb}$, Ta and Ni. Soan sand is more depleted (by $\sim 50 \%$ ) in $\mathrm{Na}$ and other mobile alkalic and alkaline-earth metals excepting $\mathrm{Ca}$ and $\mathrm{Sr}$, suggesting weathering inherited from recycling of Cenozoic Himalayan molasse exposed within and around the Potwar Plateau (Garzanti and Resentini, 2016).

\subsection{Nd isotopes}

The ${ }^{143} \mathrm{Nd} /{ }^{144} \mathrm{Nd}$ isotopic ratio provides a useful means to discriminate among different source-rock domains in the Himalayan-Karakorum orogen (e.g., Clift et al., 2002; Chirouze et al., 2015; Zhuang et al., 2015) (Appendix Tables A7 and A8). Juvenile values characterize the Ladakh and Kohistan $\operatorname{arcs}\left(\varepsilon_{\mathrm{Nd}}\right.$ mostly from 0 to +8 ; Petterson et al., 1993; Khan et al., 1997b; Rolland et al., 2002; Jagoutz et al., 2019), whereas the most radiogenic values identify the gneissic basement of the Nanga Parbat massif ( $\varepsilon_{\mathrm{Nd}}$ from -18 to -30; Whittington et al., 1999; Argles et al., 2003). Values are very negative also in Lesser Himalayan rocks $\left(\varepsilon_{\mathrm{Nd}}\right.$ mainly from -19 to -26$)$, but less negative for the Tethyan and Greater Himalaya ( $\varepsilon_{\mathrm{Nd}}$ mainly from -13 to -20; Parrish and Hodges, 1996; Whittington et al., 1999; Ahmad et al., 2000). Values intermediate between the Himalayan belt and Transhimalayan arcs characterize the Karakorum $\left(\varepsilon_{\mathrm{Nd}}\right.$ mainly from -6 to -12 ; Schärer et al., 1990; Mahéo et al., 2009). 


\section{Compositional fingerprints of Indus sand from the mountains to the deep sea}

\subsection{Petrography and heavy minerals}

The modern Upper Indus River carries feldspatho-litho-quartzose sand to the foreland basin, including a variety of sedimentary and metamorphic rock fragments, and a rich hornblendedominated tHM suite with epidote, garnet, and minor clinopyroxene, hypersthene, staurolite, titanite, kyanite, and sillimanite (Fig. 3B). In the mid-Miocene, the Burdigalian-Langhian (18-14 Ma) Kamlial Formation, exposed in the Potwar Plateau and inferred to have been largely deposited by a paleo-Indus River, contains feldspatho-quartzo-lithic sandstones including sedimentary as well as volcanic, metavolcanic, and metabasite rock fragments (Najman et al., 2003). This may represent the time when a drainage system similar to the present one was first established. The existence and compositional fingerprints of a paleo-Indus at older times remain loosely constrained (Clift et al., 2000; Roddaz et al., 2011; Zhuang et al., 2015).

Himalayan tributaries in the Punjab region carry feldspatho-litho-quartzose sand with varied sedimentary and metamorphic rock fragments and mainly moderately rich epidote-amphibolegarnet tHM suites including dravitic tourmaline, kyanite, fibrolitic sillimanite, and staurolite (Fig. 3C). Right-bank tributaries draining the sedimentary succession of the Sulaiman-Kirthar Ranges as well as Indian basement rocks of the Spinghar Crystalline (Badhsah et al., 2000) and the Waziristan, Zhob and Muslimbagh ophiolites (Gnos et al., 1997) - carry feldspatho-quartzo-lithic sedimentaclastic to lithic carbonaticlastic sand yielding very poor to moderately rich tHM suites with epidote, amphibole, clinopyroxene, and garnet. Minor ophiolitic detritus includes serpentinite grains, enstatite, olivine, and Cr-spinel.

The Lower Indus River carries feldspatho-litho-quartzose sand with mostly sedimentary and metamorphic rock fragments, and a rich amphibole-epidote-garnet tHM suite with minor clinopyroxene, titanite, tourmaline, kyanite, staurolite, hypersthene, and sillimanite (Fig. 3D). LGM to Holocene Delta sand has a very similar composition (Clift et al., 2010), with differences mostly 
518 accounted for by hydraulic-sorting effects (more micas, less heavy minerals, and especially less

high-density garnet; Fig. 3E).

Plio-Quaternary Indus Fan turbidites reported from ODP Sites 221 and 222 are more feldspathic (Q49 F31 L20; Suczek and Ingersoll, 1985) than modern Lower Indus River (Q48 F21 L31; Garzanti et al., 2005) and LGM to Holocene Delta sands (Q49 F26 L25; Clift et al., 2010). Recent data from upper Miocene to lower Pleistocene Indus Fan turbidites (Q52 F24 L25; Garzanti et al., 2020), however, indicate that their main composition is quite similar to that of the modern Lower Indus River and LGM to Holocene Delta sands (Fig. 3F), only with more abundant micas in finergrained overbank deposits (Andò et al., 2019).

\subsection{Detrital-zircon geochronology}

Zircon ages from two Upper Indus samples collected between the Kabul confluence and the Salt Range front, combined with data from one sample analysed by Zhuang et al. (2018), cluster mainly between 33 and $124 \mathrm{Ma}(\mathrm{n}=248)$. The youngest cluster occurs at 17-21 Ma (n=5) with another young age at $30 \mathrm{Ma}$ and older ages spread in the Early Cretaceous to Jurassic (127-170 Ma; n=14), Triassic to Permian (205-290 Ma; n=16), and Carboniferous to Ordovician (302-482 Ma; n=17). Zircon grains yielded common Cambrian to Neoproterozoic (485-1000 Ma; n=139) and earliest Statherian-Orosirian ages (1788-1948; n=39), and fewer Mesoproterozoic to late Statherian (1008$1669 \mathrm{Ma} ; \mathrm{n}=24)$ and earliest Orosirian to late Siderian ages (2018-2441 Ma; n=20). The oldest cluster occurs at 2449-2491 Ma (n=9) and several Archean ages were also obtained (2520-3508; $\mathrm{n}=11$ ). Such a composite age spectrum reflects the many distinct geological events that affected the diverse source-rock domains. Age spectra do not change significantly downstream of the confluence with the Soan River, a minor tributary largely recycling Himalayan molasse exposed within and around the Potwar Plateau (Critelli and Garzanti, 1994; Critelli and Ingersoll, 1994).

Sand carried by the Himalayan tributaries of the Punjab (Jhelum, Chenab, Ravi, Beas, and Sutlej samples combined; data after Alizai et al., 2011) include only a few young grains (1 late Oligocene, 
5457 Lutetian-Ypresian, 13 Mesozoic, 1 Carboniferous) and common mid-early Paleozoic (9 Devonian,

13 Silurian, 48 Ordovician, 25 Cambrian) and Neoproterozoic zircons (18 Ediacaran, 32 Cryogenian, 116 Tonian). Mesoproterozoic zircons are much less common (26 Stenian, 7 Ectasian,

9 Calymmian) than Paleoproterozoic zircons (28 Statherian, 110 Orosirian, 22 Rhyacian, 14 Siderian), and 15 Neoarchean, 4 Mesoarchean, and 3 Paleoarchean grains also occur (Appendix Table A9).

Sands in the Lower Indus River, Delta, and Fan display complex zircon-age distributions that reflect all components present in the huge catchment. The age spectrum obtained by combining data on eight modern fluvial and LGM to Holocene deltaic sands (n=766; Clift et al., 2004, 2008, 2010) reveals a marked change in age proportions relative to modern Upper Indus sand. The percentage of Eocene-Cretaceous ages is notably lower, whereas a few more Miocene-Oligocene ages and many more Silurian-Ordovician, Tonian-Stenian, and mid-Paleoproterozoic ages occur. The age spectrum obtained by combining data on five Plio-Quaternary Indus Fan sands ( $\mathrm{n}=624$; Clift et al., 2019) is quite similar, with an even lower percentage of Eocene-Cretaceous ages (Appendix Table A9).

Sand in the Indus Delta and Fan contains zircons as young as 11.3-11.7 Ma (Clift et al., 2010, 2019), which are notably younger than the youngest zircon grain found so far in the Upper Indus catchment (i.e., 15.9 Ma in Braldu sand). Zircon grains even as young as 4.4 Ma have been detected in the Indus Canyon ( $\mathrm{Li}$ et al., 2019). In this regard, it is noteworthy that such very young grains are found only in silt samples with modal grain size $\leq 40 \mu \mathrm{m}$, whereas the youngest zircon in the only sand sample analysed so far is dated as 14.2 Ma. Because such young ages were never obtained from the core of sand-sized zircon grains, it is likely that they correspond to small fragments chipped off the rim of zircon grains with an older core. In the same way, the notably greater abundance of relatively young lower Mesozoic to upper Paleozoic ages in Indus Canyon samples might reflect the greater frequency of zircon rims recording thermal events that followed the PanAfrican orogeny. The other peculiar features of Indus Canyon zircons (spectrum of 988 ages combined from ten medium silts to fine sands deposited in the last $50 \mathrm{ka}$; Li et al., 2019) are the 
much smaller population of Orosirian aged grains and the disappearance of the minor cluster around $2.5 \mathrm{Ga}$, which also may be explained by a greater frequency of analysed small grains, originally representing younger rims surrounding older crystal cores.

\subsection{Sand geochemistry}

Upper Indus sand is similar to the UCC standard, apart from a moderate enrichment in elements preferentially concentrated in densest minerals such as zircon and monazite ( $\mathrm{Zr} 254-323$ ppm, $\mathrm{Eu} / \mathrm{Eu}^{*}$ 0.51-0.61) and a depletion in $\mathrm{Na}, \mathrm{K}, \mathrm{Rb}$ and Ba preferentially hosted in alkali feldspars.

In sand carried by the Himalayan tributaries of the Punjab, most elements - except $\mathrm{Si}$, and $\mathrm{Ca}$ in Jhelum and Sutlej sands - are depleted relatively to the UCC standard (Fig. 6B), which is typical of sand including detritus recycled from sedimentary and metasedimentary rocks. Elements preferentially hosted in densest minerals are slightly enriched in the Sutlej (Zr 281 ppm, Eu/Eu* 0.43) and Jhelum samples ( $\mathrm{Zr} 230 \mathrm{ppm}, \mathrm{Eu} / \mathrm{Eu}^{*}$ 0.60) and slightly depleted in the Chenab sample (Zr $123 \mathrm{ppm}, \mathrm{Eu} / \mathrm{Eu}^{*}$ 0.72) owing to local differences in heavy-mineral concentration possibly caused by moderate selective-entrainment processes.

Relatively to Upper Indus sand, Lower Indus sand is depleted in most elements except $\mathrm{Si}, \mathrm{Ca}$, and P. This reflects major additional contribution from metamorphic and siliciclastic rocks richer in quartz. Relatively to Lower Indus River sand, LGM to Holocene deltaic sediments are instead enriched in most elements but $\mathrm{Si}, \mathrm{Y}, \mathrm{REE}, \mathrm{Zr}$ and $\mathrm{Hf}$, and especially in $\mathrm{Al}, \mathrm{Fe}, \mathrm{Mg}, \mathrm{K}, \mathrm{Rb}, \mathrm{V}, \mathrm{Co}$, $\mathrm{Ni}, \mathrm{Cu}$, and loss on ignition (Fig. 6B), which is chiefly ascribed to their finer average grain size and higher phyllosilicate content.

\subsection{Nd isotopes}

In modern Indus sand, $\varepsilon_{\mathrm{Nd}}$ values have been shown to decrease progressively from -8.4 upstream of the western syntaxis to -10.8 upstream of Tarbela Dam, and to -15.0 upstream of the delta, documenting a progressive dilution of less radiogenic and unradiogenic sediment generated in the 
Karakorum and Transhimalayan arcs by more radiogenic sediment derived from the Nanga Parbat massif and Himalayan belt (Clift et al., 2002). In LGM to Holocene sand of the Indus Delta, $\varepsilon_{\mathrm{Nd}}$ varies between -11 and -15 (Clift et al., 2010; Jonell et al., 2018), whereas in turbidites of the Indus Fan $\varepsilon_{\mathrm{Nd}}$ values remained mostly between -8.5 and -11.5 until 5.7 Ma, after which they declined to between -9 and -12 until 3 Ma and finally to between -11 and -14 thereafter (Clift et al., 2019).

\section{Provenance of Thal Desert sand}

Based on the detailed compositional information on end-member sources illustrated above, the relative contributions from each geological domain to eolian sand of the Thal Desert can be calculated by forward mixing models according to the method illustrated in Garzanti et al. (2012) and Resentini et al. (2017). These calculations are non-unique and uncertain, being affected by various sources of error including the imprecise assessment of end-member sources owing to a limited number of samples and locally significant hydraulic-sorting effects. The calculations also depend on a variety of premises that are never strictly verified, including the assumption that selective mechanical or chemical breakdown of detrital components is negligible. The accuracy of the results thus needs to be increased by performing several independent tests according to different criteria for each dataset (i.e., petrography and heavy minerals, geochemistry, zircon age spectra, and $\mathrm{Nd}$ isotopes), keeping in mind that each estimate thus obtained refers only to the investigated set of components and grain-size range (i.e., sand, transparent heavy minerals, zircon, and Nd-rich phases; Garzanti, 2016). Extrapolating such diverse and not necessarily identical or even similar provenance budgets to the entire sediment flux, which is a necessary step to calculate sediment yields and erosion rates in different parts of the catchment, is a challenging endeavour fraught with uncertainties, which requires careful consideration of mineral fertilities in each source-rock domain (Malusà et al., 2016).

\subsection{Petrography and heavy minerals}


627 The provenance budget based on integrated petrographic and heavy-mineral data from the Upper

Indus catchment and obtained after numerous sets of independent calculations indicated that bedload sand upstream of Tarbela Dam is predominantly derived from the Karakorum Range

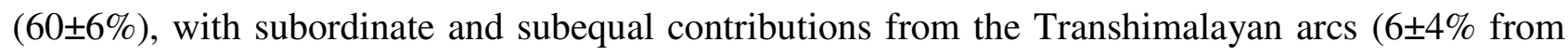
the Ladakh Arc and South Tibet; $14 \pm 4 \%$ from the Kohistan Arc) and Himalayan units (Nanga

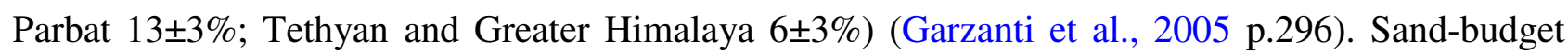
estimates are far less precise downstream of Tarbela Dam, because sediment discharge has been profoundly modified by human activities. Because of effective sediment sequestration in the Tarbela reservoir, the composition of Indus sand downstream of the Kabul confluence is very close to Kabul sand, and modern sand at the Salt Range front was estimated to be derived in significant

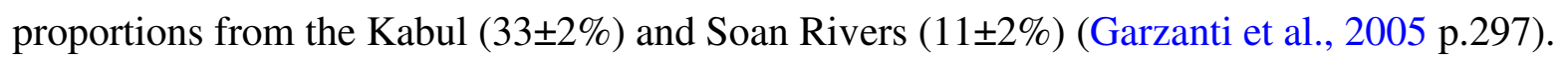

Compared to modern Upper Indus sand, Thal Desert dunes are notably poorer in quartz and sedimentary to low-rank metasedimentary rock fragments, and richer in feldspars, volcanic, metavolcanic and metabasite rock fragments, heavy minerals and especially hypersthene, documenting a significantly greater contribution from the Kohistan arc (Fig. 4). Although precise estimates are hard to obtain because of strong local selective-entrainment effects caused by wind deflation and partial overlap among end members, detrital modes of Thal dune sand can be satisfactorily reproduced as a 36:64 mixture of Kohistan and Upper Indus sand. Thal dune sand is thus assessed to be derived from the Transhimalayan arcs (40-45\%, predominantly from the Kohistan arc), the Karakorum-Hindukush Ranges (40-50\%, at least a third of which via the Kabul River according to suspended-load data of Rehman et al., 1997), the Nanga Parbat massif (<10\%), and the Himalayan belt $(<10 \%$, including detritus recycled by the Soan River).

Further clues are obtained from electron-microprobe mineral-chemical data, which showed that the Kohistan arc played the principal role as a source of the most common groups of transparent heavy minerals, especially pyroxene and epidote (Fig. 7). The South Karakorum gneiss domes undergoing fast exhumation, and to a lesser extent the Nanga Parbat massif, represent important additional 
653

$\frac{1}{624}$ 3 695 5 6,56 687 658 10 12 1650 14

$\frac{15}{16} 1$ 17 1562 19

2063 22 2064 24 2555 26 31

sources of amphibole, garnet and zircon, whereas the contribution from other Himalayan domains is major only for Lower Indus sand downstream of the Thal Desert (Lee et al., 2003; Alizai et al., 2016).

\subsection{Detrital-zircon geochronology}

In the Upper Indus catchment, Miocene grains were found only in sand of the Braldu and Hushe Rivers draining the Baltoro granite. The youngest age population found in Thal Desert (22 Ma; $3 \%$ of total zircons) and Upper Indus sand (17-21 Ma; $1 \%$ of total zircons) are thus most likely derived from the Karakorum. Oligocene to Aptian grains (46\% of total zircons in both Thal Desert and Upper Indus sand) are predominantly derived from the Karakorum Range (peaks at 24-43 Ma and 99-130 Ma) and Transhimalayan arcs (43-96 Ma). Paleozoic and Neoproterozoic grains (18\% and $30 \%$ of total zircons in Thal dunes and Upper Indus sand) are contributed by both Karakorum and Himalayan sources, whereas Orosirian grains (peak at $1.85-1.86 \mathrm{Ga} ; 16 \%$ and $7 \%$ of total zircons in Thal dunes and Upper Indus sand) are chiefly derived from the Nanga Parbat massif (Fig. 5).

A set of simple forward mixing calculations based on age groups defined by different criteria and choosing different bandwidths indicate that zircons in Thal dune sand are largely derived from the Transhimalayan arcs (34-40\%), Karakorum-Hindukush Ranges (28-34\%), Nanga Parbat massif (2021\%), and Himalayan belt (11-12\%) (Fig. 8A). Instead, zircon grains in modern Upper Indus sand are mostly derived from the Karakorum-Hindukush Ranges (60-66\%) and Transhimalayan arcs (1724\%), with minor contributions from the Nanga Parbat massif (9\%) and the Himalayan belt (7-8\%). The percentages of zircon grains supplied via the Kabul River draining both the KarakorumHindukush Ranges and the Kohistan arc cannot be estimated accurately, but is most probably significant (10-20\%), as revealed by the greater percentage of Jurassic/Triassic ages in both Upper Indus and Thal Desert sands than in any studied catchment upstream of Tarbela Dam.

\subsection{Sand geochemistry}


681 The composition of Thal Desert sand compares well with that of modern Upper Indus sand (Fig.

6A), confirming that they share the same provenance with insignificant supply from the Jhelum River or other Himalayan tributaries of the Punjab. Approximate forward mixing calculations based on bulk-sediment geochemistry suggest that $\sim 50 \%$ of the sand in the Thal dune field may be derived from the Karakorum Range, 40\% from the Kohistan arc, and only 10\% from diverse Himalayan sources. This indicates that the Kohistan arc contributed more at those times, and the Himalayan belt less, than at present.

\subsection{Nd isotopes}

The great intersample variability of $\varepsilon_{\mathrm{Nd}}$ values observed in Thal Desert sand - even in samples collected less than $30 \mathrm{~km}$ apart in the middle of the dune field - cannot be explained by differences in provenance. This is thus an exemplary case that highlights the difficulties of decoding the provenance signal carried by $\mathrm{Nd}$ isotopes, which requires full understanding of the detrital components that control the Nd budget as well as of hydraulic-sorting processes (Garçon et al., 2014). Moreover, if detritus is derived from multiple tectonic domains with overlapping signatures, as it is the case in a large river system such as the Indus draining a complex orogenic belt, then the same isotopic ratio can be produced by several different combinations of detrital sources and is therefore unable to provide an unequivocal answer (Garzanti, 2016).

Based on bulk-sand provenance budgets discussed above in subsections 7.1 and 7.3 and on average $\varepsilon_{\mathrm{Nd}}$ values given in Zhuang et al. (2015) for the Karakorum (-9.6), Ladakh-Kohistan arc (+4.9), Greater Himalaya (-14.7) and Nanga Parbat massif (-25; Clift et al., 2002), the expected $\varepsilon_{\mathrm{Nd}}$ in Thal sand would range between -3.5 and -5.5 (versus observed values between -3.5 and -13.2 ), whereas that of Indus sand upstream of Tarbela Dam would be close to -9 (versus an observed value of 10.8; Clift et al., 2002). Observed values more negative than expected - outside the $\pm 1 \varepsilon_{\mathrm{Nd}}$ uncertainty estimated by Jonell et al. (2018) - call for an explanation. 
Studies of sand generated in the Himalayan orogen have shown that $80-90 \%$ of their $\mathrm{Nd}$ is

contained in transparent heavy minerals, mostly in allanite and monazite and subordinately in titanite, apatite, other epidote-group minerals, and amphibole (Garzanti et al., 2010, 2011). The $\mathrm{Nd}$ isotopic signature of orogenic sediment is thus markedly affected by the presence of REE-rich monazite and allanite grains even where their concentration is very low (Garçon et al., 2014; Jonell et al., 2018; Garzanti et al., 2019).

High-resolution heavy-mineral data obtained with semi-automated Raman spectroscopy (Appendix Table A4) indicate that REE-rich allanite is most abundant by far in Karakorum-derived sand, minor in sand from the Greater Himalaya, and rare in sand from the Transhimalayan arcs and Nanga Parbat massif (Liang et al., 2019), whereas monazite was detected only in sand generated in the Karakorum and Greater Himalaya. The average $\varepsilon_{\mathrm{Nd}}$ value carried by monazite grains is therefore predicted to be more negative than that carried by allanite. This is corroborated by semi-automated Raman-point-counting heavy-mineral analysis, which detected significant monazite (0.3 tHM\%) and a little allanite $(0.1 \mathrm{tHM} \%)$ in sample S1462 yielding the most strongly negative $\varepsilon_{\mathrm{Nd}}$ value (13.2), a little monazite ( $0.1 \mathrm{tHM} \%)$ and no allanite in sample S1474 yielding the other strongly negative $\varepsilon_{\mathrm{Nd}}$ value (-10.9), and some allanite (0.1 and $\left.0.6 \mathrm{tHM} \%\right)$ but no monazite in samples S1470 and S1463 yielding the least negative $\varepsilon_{\mathrm{Nd}}$ values (-8.7 and -3.5$)$.

The results of heavy-mineral point-counting cannot be very precise in this regard, because the amount of monazite in our sand samples is exceedingly small. Moreover, Nd-bearing minerals may be present as undetected tiny inclusions in other detrital grains. Nevertheless, because every 100 ppm of monazite hosting $\sim 10^{5} \mathrm{ppm}$ of Nd contributes $\sim 10 \mathrm{ppm}$ of $\mathrm{Nd}$ to the bulk sand, our results suggest that most of the $\mathrm{Nd}$ in sample S1462 (containing $30 \mathrm{ppm}$ of Nd overall) and much of the $\mathrm{Nd}$ in sample S1474 (containing only 19 ppm overall) may well be provided by monazite of Greater Himalayan provenance with an $\varepsilon_{\mathrm{Nd}}$ value of $\sim 15$ (Cottle et al., 2019), thus resulting in unexpectedly low bulk-sand $\varepsilon_{\mathrm{Nd}}$ values of -13.2 and -10.9. A few monazite (or allanite) grains from the Nanga 
1 733 3 4 754 6 735 9 प्रक 6 11 12,37 14 1,538 16

Parbat massif may also be responsible for such a sharp local drop in $\varepsilon_{\mathrm{Nd}}$ values. These observations indicate that REE-rich monazite (or allanite) grains carrying a strongly negative $\varepsilon_{\mathrm{Nd}}$ fingerprint, even in amounts so small that seriously challenge the resolution power of current analytical methods, can produce an unexpectedly strong local decrease in $\varepsilon_{\mathrm{Nd}}$ values. The uncertainties of provenance budgets based on bulk-sand $\mathrm{Nd}$ isotopes are consequently increased.

\section{Provenance of Lower Indus, Indus Delta, and Indus Fan sand}

\subsection{Petrography and heavy minerals}

In the Lower Indus catchment, where the sediment flux has been profoundly modified by man, sediment-budget calculations are affected by large uncertainties. Big dams and link canals, built along both the trunk river and Punjab tributaries since Pakistan's independence in 1947 and especially after the Indus Waters Treaty in 1960, have greatly hampered sediment transit across the Punjab plains. The entire water discharge of the Ravi and Sutlej Rivers has been retained upstream in India except during monsoon floods, triggering sediment reworking and erratic mixing and blurring of provenance signals in Pakistan downstream. All along the eastern edge of the Thal Desert, changes in composition observed in sand of the Jhelum River and downstream of the Jhelum-Chenab confluence reveal fluvial reworking of Thal dune sand, which may locally represent up to more than $20 \%$ of river bedload (Garzanti et al., 2005 p.297). Forward mixing calculations based on the integrated petrographic and mineralogical dataset tentatively indicated a $39 \pm 4 \%$ contribution from the Himalayan tributaries of the Punjab to Lower Indus sand of ( $15 \pm 6 \%$ of which from the Jhelum, $33 \pm 7 \%$ from the Chenab, $4 \pm 4 \%$ from the Ravi, $40 \pm 8 \%$ from the Sutlej, and 9 $\pm 3 \%$ from reworking of Thal dunes; Garzanti et al., 2005 p.297-298).

Provenance budgets thus suggest relative supply from the Upper Indus and Himalayan tributaries of the Punjab in proportion 60:40, with very minor additional detritus from the Sulaiman-Kirthar Ranges in the west. These figures are notably similar to what is observed on the eastern side of 
peninsular India, where sediments in the Bengal Delta and Bengal Fan are assessed to be derived $\geq$ $60 \%$ from the Brahmaputra River draining the eastern Himalayan syntaxis and $\leq 40 \%$ from the Ganga River chiefly draining the Himalayan belt, with very minor additional detritus from the IndoBurman Ranges in the east (Lupker et al., 2013; Borromeo et al., 2019; Garzanti et al., 2019). A remarkable symmetry in the proportion of sediment generated from the Himalayan belt and carried by rivers draining the Himalaya exclusively or dominantly (e.g., Punjab rivers and Ganga) versus rivers sourced in Tibet and cutting across the western and eastern syntaxes (e.g., Indus and Brahmaputra) is thus observed on opposite sides of the India-Asia collision system (figure 5 in Garzanti et al., 2005).

Given the overall similarity in composition (Fig. 9A), sand budgets based on petrographic and heavy-mineral data are not drastically different for the modern Lower Indus, the LGM to Holocene Delta, and the early Pleistocene Indus Fan. However, a subtle compositional shift in detrital modes from Miocene-Pleistocene deep-sea-fan turbidites to Holocene and modern fluvio-deltaic sands points to progressively increasing relative supply from the Himalayan belt (light grey arrow in Fig. 9B), which is consistent with decreasing $\varepsilon_{\mathrm{Nd}}$ values and increasing relative abundance of zircon grains older than 300 Ma observed in Indus Fan turbidites since the latest Miocene (Clift et al., 2019). At even earlier, mid-Miocene times (18-14 Ma), a sudden influx of volcanic detritus to the foreland basin testifies to the onset of rapid exhumation of the Kohistan arc in the western Himalaya syntaxis (Kamlial Formation in Fig. 9A; Najman et al., 2003), which is consistent with increasing $\varepsilon_{\mathrm{Nd}}$ values recorded by Indus Fan turbidites from $17 \mathrm{Ma}$ to $9.5 \mathrm{Ma}$ (Clift et al., 2019).

\subsection{Detrital-zircon geochronology}

Data from Clift et al. $(2004,2008,2019)$ show that zircon grains younger than $125 \mathrm{Ma}$ - which account for $47-49 \%$ of the zircon population in Upper Indus and Thal Desert sands - are still common in LGM to Holocene sand of the Indus Delta (34\%) downstream. Young grains are also found in the Plio-Quaternary Indus Fan (17\%), although they are few in sand carried by Himalayan 
tributaries of the Punjab $(\sim 3 \%)$. This indicates that detrital zircon in the modern Lower Indus River, LGM to Holocene Delta, and Plio-Quaternary Fan is derived from the Upper Indus and Punjab tributaries in roughly similar proportions (Fig. 8B), with notable short-term variations in space and time (Clift et al., 2008, 2019; Li et al., 2019). Despite a zircon-age dataset that has been rapidly expanded in the last decade, estimates of zircon contributions from various parts of the catchment still vary widely. Alizai et al. (2011, their table 7 and figure 12A) estimated that two-thirds of zircon grains in the modern delta are supplied by the Himalayan tributaries of the Punjab (two-thirds of which by the Sutlej River), which is largely explained by the high zircon fertility of Himalayan rocks. Our set of forward mixing calculations, based on age groups defined by diverse criteria, suggest that the Upper Indus may have supplied on average $45-48 \%$ of detrital zircon to the PlioQuaternary Fan and up to 55-67\% of detrital zircon to the LGM-Holocene Delta. Similar, but less robust estimates are obtained from Indus Canyon zircon-age data (Li et al., 2019), which is largely ascribed to the finer grain-size of the analysed zircons and short timescale variability. The different proportions of original cores and rims of zircon grains in samples of markedly different grain size may explain the notable variability observed even at the centennial to millennial time scale, which may be at least partly caused by the variable grain size of the studied samples rather than by provenance changes.

\subsection{Sand geochemistry}

The geochemical composition of modern Lower Indus sand indicates a much higher percentage of Himalayan detritus than in Thal Desert and Upper Indus River sands (Fig. 6B). Forward mixing calculations, affected by the same uncertainties discussed for the petrographic-mineralogical sand budget illustrated in subsection 8.1 above, suggest that the Upper Indus and the Himalayan tributaries of the Punjab provide sand in roughly equal amounts to the Lower Indus and LGM to

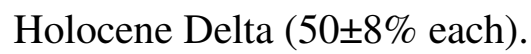

\subsection{Nd isotopes}


814

815

2

816 4

5 8617 7 8918 10 P19 12 1820 14

15 17

$\mathrm{Nd}$ isotopes have long been used to identify sediment sources and to trace erosion patterns in the huge Indus drainage basin. In modern Indus River sand, the sharp decrease in $\varepsilon_{\mathrm{Nd}}$ values across the foreland basin documents the progressive dilution of detritus shed from more juvenile Karakorum and Transhimalayan arc sources by more radiogenic Himalayan detritus supplied by the Punjab tributaries in the lower course (Clift et al., 2002). Values as negative as -15.4 in the modern delta contrast with less negative values measured from Pleistocene Indus Fan sediments cored at ODP Site $720\left(\varepsilon_{\mathrm{Nd}}-12.5\right.$ and -14.0; Clift et al., 2001) and IODP Sites U1456 and U1457 ( $\varepsilon_{\mathrm{Nd}}-9.5$ and 13.0; Clift et al., 2019; Yu et al., 2019). Although this discrepancy may partly result from reduced sediment flux from the Upper Indus after the closure of the Tarbela Dam, Indus Delta sediments do document a progressive increase of detrital supply from the radiogenic Lesser Himalaya since the Last Glacial Maximum (LGM), with relatively reduced contributions from Transhimalayan and Karakorum sources. The $\varepsilon_{\mathrm{Nd}}$ values decreased from -11 to -12 between the LGM and the beginning of the Younger Dryas $(\sim 12.7 \mathrm{ka})$, to reach -15 around $-8.7 \mathrm{ka}$, a change ascribed to enhanced erosion along the southern Himalayan front caused by the increasing intensity of summer monsoon rains (Clift et al., 2008, 2010).

Upper Miocene to Pleistocene Indus Fan sediments recently drilled by IODP Expedition 355 to the Laxmi Basin also show less radiogenic $\varepsilon_{\mathrm{Nd}}$ values than recent sediments in the Indus Delta, with a pronounced decline throughout the Pliocene ascribed to an accelerated exhumation of the Lesser Himalaya and, to a lesser extent, of the Nanga Parbat massif (Clift et al., 2019). Laxmi Basin sediments deposited during the last $600 \mathrm{ka}$ yielded less radiogenic $\varepsilon_{\mathrm{Nd}}$ values mostly between -9.5 and -13.0, which however reflects mixing of sediment supplied not only by the Indus River but also by rivers draining Deccan Trap basalts in Peninsular India (Yu et al., 2019), as independently documented by heavy-mineral data (Garzanti et al., 2020).

\section{Climatic control on latest Quaternary erosion patterns}


841 In provenance studies, each one of the many different possible approaches adds useful

2

complementary information but hardly ever provides a sharp univocal response. Among bulksediment methods, petrographic analysis applies to bedload sand only and geochemistry has limited discrimination power with the notable exception of mafic source rocks. Heavy-mineral suites are strongly affected by hydraulic sorting and selective chemical dissolution during the successive stages of a sedimentary cycle. Age spectra of detrital zircon are strongly distorted by fertility effects and heavily biased in favour of felsic igneous and metaigneous sources; moreover, grains recycled even several times from siliciclastic covers cannot be distinguished from first-cycle grains derived directly from basement rocks. $\mathrm{Nd}$ isotopic ratios suffer from overlap among the fingerprints of diverse source-rock domains, are strongly influenced by grain size and hydraulic-sorting effects, and are highly dependent on rare minerals very rich in REE such as monazite, which can control the Nd budget even if present in amounts so small that can hardly be assessed precisely enough by current techniques.

Nevertheless, the evidence provided by these different methods combined, as illustrated in Sections 4, 5 and 6 and discussed in Sections 7 and 8, indicates robustly enough that the Thal dune field was fed entirely by the paleo-Upper Indus at a time when erosion was focused to the north of the Himalayan belt, and specifically in the Kohistan arc and Karakorum Range. All provenance budgets based on integrated petrographic-mineralogical data, bulk-sediment geochemistry, age spectra of detrital zircon, and $\mathrm{Nd}$ isotope ratio converge to indicate that Thal Desert sand was originally derived $\sim 40 \%$ from erosion of the Kohistan arc, up to $50 \%$ from the Karakorum Range, and only in minor amount from diverse Himalayan sources. Instead, $\sim 60 \%$ of modern Indus sand upstream of Tarbela Dam is assessed to be derived from the Karakorum, the rest being supplied in subequal amounts by the Transhimalayan arcs and the Himalayan belt.

In Thal Desert sand, the low abundance of quartz and high abundance of feldspars and volcanic, metavolcanic and metabasite rock fragments, the very rich tHM suites including common 
866

1 867 3 868 6 869 8 890 10 11 82 13 1842 15

363 88/4

195 2176 22

hypersthene, the common zircon grains of Late Cretaceous to early Paleogene age, and the $\varepsilon_{\mathrm{Nd}}$ values less negative than those of Upper Indus sand and as high as -3.5 are all clear evidence of major contribution from the Kohistan arc. Notably greater detrital supply from juvenile sources lying to the north of the Himalayan belt than in the modern Upper Indus system indicates markedly different conditions of sediment generation at a time when the paleo-Upper Indus delivered to the foreland basin volumes of sand to be subsequently reworked by wind and accumulated in the Thal dune field.

\subsection{Eolian sedimentation in the dry latest Pleistocene}

A precise chronology of the evolution of the Thal Desert has not been established yet, whereas thermoluminescence dating of eolian sediments in the Thar Desert of southern Pakistan has revealed multistep phases of dune accretion through the last $200 \mathrm{ka}$ alternating with precessiondriven interludes of wetter climate (Singhvi et al., 2010). The last major phase of dune growth in the eastern Thar Desert took place under a transitional climate, when SW monsoon winds were being re-established following a peak in aridity during the LGM characterized by a very weak SW monsoon. Sand aggradation in the eastern desert took place between $17 \mathrm{ka}$ and $14 \mathrm{ka}$ and lasted until $9 \mathrm{ka}$, at the onset of the early Holocene wet stage (Dhir et al., 2010; Singhvi et al., 2010). In contrast, the western Thar Desert has been supplied by sediment from the Indus Delta since the onset of the wetter Holocene and expanded further west as the climate dried after the mid-Holocene (East et al., 2015). The recent finding of Mesolithic artefacts dated as the first millennia of the Holocene on top of sand dunes of both Thar and Thal Deserts (Biagi et al., 2019), suggests that a chronology similar to the eastern Thar Desert may be extrapolated to the Thal Desert.

The compositional fingerprints of Thal dunes indicate that detritus was largely generated by erosion in the high Karakorum and Kohistan Ranges in the northern part of the western Himalayan syntaxis (Fig. 9A). During deglaciation following the LGM, sediment fluxes were augmented by incision of moraines and fluvial terraces in the mountains (Clift and Giosan, 2014; Blöthe et al., 2014; Jonell et 
al., 2017b). In this latest Pleistocene period of weak summer monsoonal rains, meltwater fluxes

from shrinking mountain glaciers were insufficient to guarantee a constant full sediment-transport capacity to the paleo-Upper Indus River, fluvial sediments were dumped and extensively reworked by wind in the lowlands, and sand blown by progressively strengthening winds accumulated in dune fields all across the dry foreland basin (Fig. 10A).

In the Indus Delta, a ravinement surface formed at this time of sea-level rise, as documented by a hiatus separating sand deposited during the LGM (radiocarbon ages $28.7 \mathrm{ka}$ and $38.9 \mathrm{ka}$ ) from the overlying sediments deposited since $\sim 15 \mathrm{ka}$ and documenting sustained progradation since $\sim 12 \mathrm{ka}$ (Clift et al., 2008, 2010). Sediments deposited during and immediately after the LGM carry a notably less negative isotopic signature $\left(\varepsilon_{\mathrm{Nd}}-11\right.$ to -12$)$ than more recent deposits, which confirms a greater contribution from juvenile Transhimalayan sources at those times (Fig. 8B). The $\varepsilon_{\mathrm{Nd}}$ values started to decrease with the beginning of the Younger Dryas, a consequence of increasingly focalized erosion along the southern Himalayan front (Clift et al., 2010). Changing climatic conditions since the LGM have certainly contributed to such a prominent shift in erosion patterns and accelerated erosional denudation of the Himalayan belt (Clift et al., 2008, 2019).

\subsection{Changing landscapes in the Holocene}

Global warming and intensification of the South Asian monsoon led to much wetter conditions in the early Holocene, when water and sediment discharge from the Himalayan orogen very markedly increased, fuelled by heavier monsoonal rains. This is documented by notably enhanced freshwater influx peaking around $10.8 \mathrm{ka}$, as recorded by low $\delta^{18} \mathrm{O}$ in foraminifera off the coast of Pakistan (Staubwasser et al., 2002) and by progradation of the Indus Delta even at a time of rapid sea-level rise, fostered by augmented sediment delivery between $13 \mathrm{ka}$ and $9.5 \mathrm{ka}$ (Giosan et al., 2006b). On the opposite side of Peninsular India, the strengthened early Holocene monsoon is held responsible for greatly increased sediment supply to the Bengal Delta between $\sim 11 \mathrm{ka}$ and $7 \mathrm{ka}$ (Goodbred and Kuehl, 2000). This wet period fostered the formation of lakes in the Thar Desert from $\sim 7$ ka to $\sim 5$ 

1
921 3 ${ }_{5}^{4} 2$ 6 923 8

ka (Enzel et al. 1999; Roy et al., 2009). Lakes desiccated at the onset of a new arid phase at $\sim 4 \mathrm{ka}$ (Giosan et al., 2012; Dixit et al., 2014), which was followed by several other wet events of shorter duration and smaller magnitude (Prasad and Enzel, 2006).

The Thal Desert, therefore, testifies to the markedly different landscape that preceded the wet early Holocene, when strongly enhanced water discharge led to incision and reworking of the Thal and Thar dune fields by the Indus and its Punjab tributaries draining the Himalayan front, directly and most strongly hit by the heavy rains brought in by the renewed strength of the South Asian monsoon (Fig. 10B).

\section{Conclusions}

The distinctive petrographic, heavy-mineral, mineral-chemical, U-Pb zircon-age, geochemical, and Nd-isotope fingerprints of Thal Desert sand reveal that this dune field was fed entirely by the paleoUpper Indus at a time when erosion was focused in the Kohistan arc and Karakorum Range to the north of the Himalayan belt. Thermoluminescence chronology and artefacts dated at the first millennia of the Holocene found on top of sand dunes of both Thal and Thar Deserts indicate that these dune fields expanded in semi-dry climate during the latest Pleistocene. In this period, global warming and glacial retreat following the Last Glacial Maximum fostered enhanced detrital supply from the high Kohistan and Karakorum Ranges of the western Himalayan syntaxis. When meltwater fluxes from shrinking mountain glaciers were reduced, at a time of weak monsoonal rains, the sediment-transport capacity of the paleo-Upper Indus River was also reduced. Fluvial sediments were dumped and extensively reworked by wind in the lowlands, and sand accumulated in dune fields across the dry foreland basin. Sand stored in the Thal dune field thus testifies to a major change in Himalayan landscape and erosion patterns that took place at a time of rapid climatic transition from dry periglacial settings during the Last Glacial Maximum to wet conditions in the early Holocene, when markedly enhanced river water and sediment discharge was fuelled by intensified monsoonal rainfall. 


\section{ACKNOWLEDGMENTS}

Heartfelt thanks to Giacomo Ghielmi and Filippo Lazzati, who collected sand samples in the Thal

Desert and around the western Himalayan syntaxis, and to Henry Munack and Jan Blöthe who

1952 11

123 14

1554 16

7755 19 256 21

provided samples from Ladakh. The Braldu and Hushe samples were collected and kindly provided by Mike Searle. Guido Pastore helped with several geochronological analyses. This study was supported financially by Projects MIUR-PRIN 2015EC9PJ5 "The subduction and exhumation of the continental lithosphere: their effects on the structure and evolution of the orogens" and MIUR Dipartimenti di Eccellenza 2018-2022, Department of Earth and Environmental Sciences, University of Milano-Bicocca. We warmly thank ESR Editor Chris Fielding and an anonymous reviewer for their useful comments and constructive advice.

\section{SUPPLEMENTARY MATERIALS}

Supplementary data associated with this article, to be found in the online version at http://dx.doi.__ , include information on sampling sites (Table A1), together with the complete datasets on sand petrography (Table A2), heavy minerals (Table A3), heavy-mineral point-counting by semi-automated Raman spectroscopy (Table A4), percentages of amphibole, garnet, epidote, and pyroxene varieties in each source-rock domain (Table A5), sand geochemistry (Table A6), and $\mathrm{Nd}$ isotopes (Table A7). A compilation of $\mathrm{Nd}$ isotope values from bedrocks and sediments from the Himalayan-Karakorum orogen is shown in Table A8 and original and literature data on zircon-age distributions are summarized in Table A9, whereas the full original detritalzircon geochronology dataset is illustrated in Appendix B. The Google-Earth ${ }^{\mathrm{TM}}$ map of sampling sites Thal Review.kmz is also provided. 


\section{FIGURE CAPTIONS}

Figure 1. The Thal Desert is situated where the Upper Indus reaches the foreland basin to the south of the western Himalayan syntaxis (WHS) and to the west of the Punjab plain. Location of the four studied Thal dune samples is indicated by orange stars. Inset shows area enlarged in the Google Earth $^{\mathrm{TM}}$ image; the white circle indicates the Indus Canyon, and the white star the location of the Laxmi Basin targeted by IODP Expedition 355. Ga and $\mathrm{Br}=$ Ganga and Brahmaputra Rivers.

Figure 2. Geological map of the Indus catchment (mod. after Garzanti et al., 2005) indicating the studied Indus tributaries and sampling sites. Blue stars in the Indus Delta indicate location of the Thatta (T), Jati (J), and Keti Bandar (K) cores.

Figure 3. Sand petrography. Thal Desert sand is enriched in plagioclase, volcanic to metabasite rock fragments, and pyroxenes (A; S1462) relative to Upper Indus sand (B; S1447). Sand supplied by Punjab tributaries downstream of the Thal Desert includes abundant metasedimentary detritus from the Himalaya (C; S1424). Sands in the Lower Indus River (D; S1487), Holocene Delta (E; sample TH10_8 in Clift et al., 2010) and lower Pleistocene Fan (F; sample U1456 39F1W130/132, collected during IODP Expedition 355; Pandey et al., 2016) are notably poorer in feldspars and richer in quartz, metasedimentary rock fragments and micas relatively to Thal dunes. All samples with crossed polarizers; blue bar for scale $=100 \mu \mathrm{m}$.

Figure 4. Detrital modes of Thal Desert dunes compared with sand carried by the Upper Indus and its tributaries draining the diverse geological domains of the western Himalayan syntaxis (QFL and LmLvLs diagrams after Ingersoll et al., 1984). Thal dune sand contains more feldspars, more volcanic, metavolcanic, and metabasite rock fragments, more heavy minerals, and more hypersthene than modern Upper Indus sand, indicating greater contribution from the Kohistan arc. 
$999 \mathrm{Q}=$ quartz; $\mathrm{F}=$ feldspar; $\mathrm{L}=$ lithic grains $(\mathrm{Lm}=$ metamorphic $; \mathrm{Lv}=$ volcanic; $\mathrm{Ls}=$ sedimentary $)$;

$10 \frac{1}{2} 0$ other parameters as in Table 1. Data in the LmLvLs and heavy-mineral triangular diagrams are 3 centered to allow better visualization (von Eynatten et al., 2002).

1092

Figure 5. U-Pb age spectra of detrital zircons in Thal dunes and in sands carried by the Upper Indus and its tributaries. Zanskar data after Jonell et al. (2017a); Dir and most Upper Hunza ages after Zhuang et al. (2018). Main events of crustal growth in the western Himalayas are indicated. The multimodal spectrum of Thal sand indicates dominant zircon supply from the western Himalayan syntaxis, including the Karakorum Range (Baltoro granite, South Karakorum gneiss domes, and central batholith) and Transhimalayan arcs (ages from 20 to $130 \mathrm{Ma}$ ), together with the Nanga Parbat massif (sharp $1.85 \mathrm{Ga}$ peak). Contribution from the Greater and Tethys Himalaya is subordinate (mostly Neoproterozoic ages).

Figure 6. Sedimentary geochemistry. Elements are arranged following the periodic table group by group and data are normalized to the median composition of average Upper Indus (A) and Lower Indus sand (B) (Appendix Table A6). A) Note: i) similar composition of Thal Desert and Upper Indus sands, which have higher concentration in most chemical elements relatively to Himalayanderived sand; ii) peculiar composition of Kohistan sand, with high $\mathrm{Mg}, \mathrm{Sc}, \mathrm{V}, \mathrm{Co}, \mathrm{Ni}$ and $\mathrm{Cu}$, and low $\mathrm{Th}, \mathrm{U} \mathrm{Nb}$, Ta, and $\mathrm{Eu}$ anomaly; iii) low $\mathrm{Cr}$ and $\mathrm{Ni}$ in Ladakh sand; iv) heavy-mineral enrichment and strongly negative $\mathrm{Eu}$ anomaly in Hispar sand, owing to a local selectiveentrainment effect. B) Note: i) both Thal Desert and Upper Indus sands have higher concentration in most chemical elements than Himalayan-derived sand of Punjab tributaries; ii) high K, Rb, V, Ni and $\mathrm{Cu}$ in finer-grained sediments of the LGM to Holocene Indus Delta (data after Clift et al., 2010); iii) markedly variable Eu anomaly in both Thal Desert and Punjab tributary sands chiefly controlled by local selective-entrainment effects (Garzanti et al., 2010). 
1025 Figure 7. MDS maps based on electron-microprobe chemical analyses of amphibole, garnet,

1026 3 1027 5 $10 \frac{1}{8} 8$ 8 1029 10 1030 12 13 1041 15 17932 17 11833 20 18134 22 12335 25 12636 27 14837 30 13038 32 13339 34 35 350 37 13841 39

1442 42 140843 44 14544 47 14845 49 15946 51 52 15037 54 $15 \sqrt{48}$ 56 1574 59 1650 61

epidote, and pyroxene (mod. after figure 7 in Liang et al., 2019). The Kohistan arc is indicated as the main supplier of epidote $(\mathbf{A})$ and pyroxene $(\mathbf{B})$, whereas amphibole $(\mathbf{C})$ and garnet $(\mathbf{D})$ were largely derived from the Karakorum Range (Hispar River), Nanga Parbat massif, and Himalayan belt.

Figure 8. MDS maps based on U-Pb age spectra of detrital zircons highlight focused erosion of the western Himalayan syntaxis at LGM times and increasing contributions from the Himalayan belt in the Holocene. A) Thal dunes show a greater affinity with Transhimalayan arcs than Upper Indus sand. Zanskar data after Jonell et al. (2017a); Dir, Kabul, and most Upper Hunza ages after Zhuang et al. (2018). B) Sands of the Lower Indus, Thar dunes, and Pleistocene Fan plot close to Himalayan tributaries of the Punjab, showing strong Himalayan influence. Instead, Holocene and especially LGM Delta sands display closer affinity to sands of the Upper Indus, Thal dunes, and Transhimalayan arcs. Data sources: Punjab tributaries and Thar Desert (Alizai et al., 2011); Lower Indus River (Clift et al., 2004); LGM to Holocene Indus Delta (Clift et al., 2008, 2010; 4 samples combined from Thatta, Jati, and Keti Bandar cores, age 6.6-9.7 ka, n=288; 2 samples combined from Keti Bandar core, age 28.7 ka, n=229); Indus Canyon (Li et al., 2019; 6 samples combined, age 0.4-6.7 ka, n=507); Indus Fan (Clift et al., 2019; sample U1456A-11H-6 60/69, age 0.9 ka). Eastern Karakorum: Hushe + Braldu samples; western Karakorum: Upper Hunza + Hispar samples.

Figure 9. Petrography and heavy minerals in Indus River sands, from the western Himalayan syntaxis to the deep sea. A) Quartz increases downstream of the Thal Desert because of major supply from Punjab tributaries draining the Himalayan belt. Rock fragments are dominantly sedimentary in sand from the Kirthar Range but locally include volcanic/metavolcanic and ultramafic types shed by the Waziristan and Zhob ophiolites in sand from the Sulaiman Range. Otherwise, modern sand in the Indus sedimentary system includes a variety of sedimentary and 
1051 metamorphic grains with subordinate volcanic/metavolcanic types. Volcanic rock fragments are $10 \frac{1}{2} 2$ most abundant in the Kamlial Formation, reflecting incipient dissection of the Kohistan arc at mid3 1053 5 1054 8 1055 10 1056 12 13 1.057 15 17538 17 17959 20 18160 22

Miocene times (Najman et al., 2003). B) A progressive shift in detrital modes indicates increasing contribution from Himalayan tributaries of the Punjab from Miocene-Pleistocene fan turbidites to Holocene deltaic and modern Lower Indus fluvio-deltaic sands (light grey arrow). Q = quartz; F = feldspar; L = lithic grains; Ky = kyanite; Sil = sillimanite; Sp = Cr-spinel; St = staurolite; other parameters as in Table 1. Data sources: modern sand (Garzanti et al., 2005), LGM to Holocene Delta (Clift et al., 2010), Upper Miocene-Pleistocene Fan, IODP sites U1456 and U1457 (Garzanti et al., 2020).

Figure 10. Drastically changing landscapes in the western Himalayan foreland basin driven by latest Quaternary climate change. Pictures in rectangles aim at representing natural sceneries and life conditions at the time, from mountain higlands to the coastal plain. Circles represent rough proportions of detritus contributed by the Upper Indus (orange dots) versus the Himalayan tributaries of the Punjab (blue dots). A) In the dry latest Pleistocene, during deglaciation following the LGM, sediment fluxes were largely generated by incision of moraines and fluvial terraces in the high Kohistan and Karakorum Ranges surrounding the western Himalayan syntaxis. B) In the wet early Holocene, water and sediment fluxes were instead largely fuelled by heavy rainfall along the southern front of the Himalayan belt directly hit by humid air masses brought in by the intensified summer monsoon.

Table 1. Petrographic and heavy-mineral signatures of Thal Desert sand compared with sands carried by the Indus River and its tributaries draining different source-rock domains. Data sources: Miocene Kamlial Formation (Najman et al., 2003); Indus Delta cores (Clift et al., 2010); modern Indus sands and Neogene Indus Fan turbidites (Garzanti et al., 2005, 2020). Q = quartz; F = feldspars $(\mathrm{KF}=\mathrm{K}$-feldspar; $\mathrm{P}=$ plagioclase $; \mathrm{L}=$ lithic grains $(\mathrm{Lvm}=$ volcanic and metavolcanic; $\mathrm{Lc}$ 
1077 = carbonate and metacarbonate Lh = chert Lsm = shale, siltstone, slate, and metasiltstone; $\mathrm{Lmf}=$

$10 \frac{1}{2} 8$ felsic metamorphic; $\mathrm{Lmb}=$ metabasite; $\mathrm{Lu}=$ ultramafic); $\mathrm{HM}=$ heavy minerals; $\mathrm{MI}^{*}=$ 3

1079 Metamorphic Index; tHMC $=$ transparent heavy-mineral concentration. ZTR $=$ zircon + tourmaline 5

$10 \frac{8}{8} 0$ + rutile; Ttn = titanite; Ep = epidote-group minerals; Grt = garnet; SKS = staurolite + kyanite + 8

1081 sillimanite; Amp = amphibole; $\mathrm{Px}=$ pyroxene $(\mathrm{Cpx}=$ clinopyroxene Opx $=$ orthopyroxene, mostly 10

10 hypersthene); \&tHM = other transparent heavy minerals (apatite, chloritoid, Cr-spinel, olivine, 11383 prehnite, pumpellyite, brookite, andalusite, barite).

17884

17 
1085

$10 \frac{1}{2} 6$

1087

1088

6

7

1089

1090 11

${ }_{13}^{12} 1$

1 (1) 2

15

16

11)93

18

1094

2095 22

10396

12857

26

27

1288

29

13099

13100

1331

35

$1316) 2$

37

1318)

39

1404

$14 \sqrt{4} 25$

43

1,106

$1_{47}^{4} 907$

48

141908

50

15109

52

15130

54

1551

${ }_{58}^{57}$

15913

16114

62

63

64

65

\section{REFERENCES}

Ahmad, T., Harris, N., Bickle, M., Chapman, H., Bunbury, J., Prince, C., 2000. Isotopic constraints on the structural relationships between the Lesser Himalayan Series and the High Himalayan Crystalline Series, Garhwal Himalaya. Geological Society of America Bulletin, 112, 467-477.

Ali, K.F., De Boer, D.H., 2007. Spatial patterns and variation of suspended sediment yield in the upper Indus River basin, northern Pakistan. Journal of Hydrology, 334, 368-387.

Ali, K.F., De Boer, D.H., 2008. Factors controlling specific sediment yield in the upper Indus River basin, northern Pakistan. Hydrological Processes, 22, 3102-3114.

Alizai, A., Carter, A., Clift, P.D., Van Laningham, S., Williams, J.C., Kumar, R., 2011. Sediment provenance, reworking and transport processes in the Indus River by U-Pb dating of detrital zircon grains. Global and Planetary Change, 76, 33-55.

Alizai, A., Clift, P.D., Still, J., 2016. Indus Basin sediment provenance constrained using garnet geochemistry. Journal of Asian Earth Sciences, 126, 29-57.

Andò, S., Garzanti, E., 2014. Raman spectroscopy in heavy-mineral studies. In: Scott, R.A., Smyth, H.R., Morton, A.C., Richardson, N. (Eds.), Sediment Provenance Studies in Hydrocarbon Exploration and Production. Geological Society: London, UK, Special Publication 386, pp. 395412 .

Andò, S., Aharonovich, S., Hahn, A., George, S.C., Clift, P.D., Garzanti, E., 2019. Integrating heavy-mineral, geochemical, and biomarker analyses of Plio-Pleistocene sandy and silty turbidites: a novel approach for provenance studies (Indus Fan, IODP Expedition 355). Geological Magazine, https://doi.org/10.1017/S0016756819000773

Argles, T., Foster, G., Whittington, A., Harris, N., George, M., 2003. Isotope studies reveal a complete Himalayan section in the Nanga Parbat syntaxis. Geology, 31(12), 1109-1112.

Badshah, M.S., Gnos, E., Jan, M.Q., Afridi, M.I., 2000. Stratigraphic and tectonic evolution of the northwestern Indian plate and Kabul Block. Geological Society, London, Special Publications, $170,467-476$.

Beck, R.A., Burbank, D.W., Sercombe, W.J., Riley, G.W., Barndt, J.K., Berry, J.R., Afzal, J., Khan, A.M., Jurgen, H., Metje, J., Cheema, A., Shafique, N.A., Lawrence, R.D., Khan, M.A., 1995. Stratigraphic evidence for an early collision between Northwest India and Asia. Nature, 373 (6509), 55-58. 
1115 Biagi, P., Starnini, E., Ghauri, Z.S., 2019. Mahi Wala 1 (MW-1): a Mesolithic site in the Thal desert 1116 of Punjab (Pakistan). Asian Archaeology, https://doi.org/10.1007/s41826-019-00024-z.

2

1137

$11_{6}^{5} 8$

$11_{8}^{7} 19$

9

1120

11

1121

13

1142

15

16

11723

1724

1325

22

14326

24

12527

26

12728

28

139

13130

131331

34

35

13162

13733

1394

1435

43

14146

45

1467

47

49

${ }_{51}^{5} 39$

15240

53

54

151541

56

1542

58

59

60

61

62

63

64

65

Blöthe, J.H., Munack, H., Korup, O., Fülling, A., Garzanti, E., Resentini, A., Kubik. P.W., 2014. Late Quaternary valley infill and dissection in the Indus River, western Tibetan Plateau margin. Quaternary Science Reviews, 94, 102-119.

Borromeo, L., Andò, S., France-Lanord, C., Coletti, G., Hahn, A., Garzanti, E., 2019. Provenance of Bengal Shelf Sediments: 1. Mineralogy and Geochemistry of Silt. Minerals, 9, 640, doi:10.3390/min9100640.

Burbank, D.W., Leland, J., Fielding, E., Anderson, R.S., Brozovic, N., Reid, M.R., Duncan, C., 1996a. Bedrock incision, rock uplift and threshold hillslopes in the northwestern Himalayas. Nature, 379, 505-510.

Burbank, D.W., Beck, R.A., Mulder, T., 1996b. The Himalayan foreland basin. In: Yin, A., Harrison, T.M. (Eds.), The Tectonic Evolution of Asia (World and regional geology). Cambridge University Press, Cambridge, UK, pp.149-188.

Burg, J.P., 2011. The Asia-Kohistan-India collision: review and discussion. In: Brown, D., Ryan, P.D. (Eds.), Arc-Continent Collision, Frontiers in Earth Sciences, Springer Berlin Heidelberg, pp. 279-309.

Cerveny, P.F., Johnson, N.M., Tahirkheli, R.A.K., Bonis, N.R., 1989. Tectonic and geomorphic implications of Siwalik group heavy minerals, Potwar plateau, Pakistan. In: Malinconico, L.L., Lillie, R.J. (Eds.), Tectonics of the Western Himalayas. Geological Society of America, Special Papers, 232, pp. 129-136.

Chirouze, F., Huyghe, P., Chauvel, C., van der Beek, P., Bernet, M., Mugnier, J.-L., 2015. Stable drainage pattern and variable exhumation in the Western Himalaya since the Middle Miocene. The Journal of Geology, 123, 1-20, doi.org/10.1086/679305.

Clift, P.D., 2017. Cenozoic sedimentary records of climate-tectonic coupling in the Western Himalaya. Progress in Earth and Planetary Science, 4, 39, doi10.1186/s40645-017-0151-8.

Clift, P.D., Giosan, L., 2014. Sediment fluxes and buffering in the post-glacial Indus Basin. Basin Research, 26, 369-386, doi:10.1111/bre.12038. 
1143

1144 1245 4 $1 \frac{5}{6} 6$ $11_{8}^{7} 47$ 11948 10 11 11249 1350 1,51 ${ }_{18}^{17} 752$ 19 12क 3 21 12154 23 155 25

1356 1497 29 1358 31 13159 33

1340 ${ }_{3}^{3} 61$ 13882 39 14163 41 141264 43 1445 45

14966 1487 15168 51 52 15169 54 1550 56 1587 15192 60 61 62

Clift, P., Shimizu, N., Layne, G., Gaedicke, C., Schlter, H.U., Clark, M., Amjad, S., 2000. Fifty-five million years of Tibetan evolution recorded in the Indus Fan. Eos, Transactions American Geophysical Union, 81, 277-281.

Clift, P.D., Shimizu, N., Layne, G., Blusztajn, J.S., Gaedicke, C., Schluter, H.-U., Clark, M.K., Amjad, S., 2001. Development of the Indus Fan and its significance for the erosional history of the Western Himalaya and Karakoram. Geological Society of America Bulletin, 113, 1039-1051.

Clift, P.D., Lee, J.I., Hildebrand, P., Shimizu, N., Layne, G.D., Blusztajn, J., Blum, J.D., Garzanti, E., Khan, A.A., 2002. Nd and Pb isotope variability in the Indus River System: implications for sediment provenance and crustal heterogeneity in the Western Himalaya. Earth and Planetary Science Letters, 200(1-2), 91-106.

Clift, P.D., Campbell, I.H., Pringle, M.S., Carter, A., Zhang, X., Hodges, K.V., Khan, A.A., Allen, C.M., 2004. Thermochronology of the modern Indus River bedload: New insight into the controls on the marine stratigraphic record. Tectonics, 23(5), doi:10.1029/2003TC001559.

Clift, P., Giosan, L., Blusztajn, J., Campbell, I.H., Allen, C., Pringle, M., Tabrez, A.R., Danish, M., Rabbani, M.M., Alizai, A., Carter, A., Lückge, A., 2008. Holocene erosion of the Lesser Himalaya triggered by intensified summer monsoon. Geology, 36, 79-82, doi: 10.1130/G24315A.1.

Clift P.D., Giosan L., Carter A., Garzanti E., Galy V., Tabrez A.R., Pringle M., Campbell I.H., France-Lanord C., Blusztajn J., Allen C., Alizai A., Lückge A., Danish M., Rabbbani M.M., 2010. Monsoon control over erosion patterns in the Western Himalaya: possible feed-backs into the tectonic evolution. In: Clift P.D., Tada R. and Zheng H. (Eds.), Monsoon evolution and tectonic-climate linkage in Asia, Geological Society London, Special Publication 342, pp. 185218

Clift, P.D., Carter, A., Giosan, L., Durcan, J., Duller, G.A., Macklin, M.G., Alizai, A., Tabrez, A.R., Danish, M., Van Laningham, S., Fuller, D.Q., 2012. U-Pb zircon dating evidence for a Pleistocene Sarasvati River and capture of the Yamuna River. Geology, 40(3), 211-214.

Clift, P.D., Zhou, P., Stockli, D.F., Blusztajn, J., 2019. Regional Pliocene exhumation of the Lesser Himalaya in the Indus drainage. Solid Earth, 10, 647-661.

Comas-Cufí, M., Thió-Henestrosa, F.S., 2011. CoDaPack 2.0: a stand-alone, multi-platform compositional software. 
1173 Cottle, J., Lederer, G., Larson, K., 2019. The monazite record of pluton assembly: Mapping 11174 Manaslu using petrochronology, Chemical Geology, 530, 119309,

$1 \frac{2}{13} 5$ 4

$11 \frac{5}{6} 6$ 1177 1198 10

117 129 https://doi.org/10.1016/j.chemgeo.2019.119309.

Crawford, M.B., Searle, M.P., 1992. Field relationships and geochemistry of pre-collisional (IndiaAsia) granitoid magmatism in the central Karakoram, northern Pakistan. Tectonophysics, 206, 171-192.

Critelli, S., Garzanti, E., 1994. Provenance of the Lower Tertiary Murree redbeds (Hazara-Kashmir syntaxis, Pakistan) and initial rising of the Himalayas. Sedimentary Geology, 89, 265-284.

Critelli, S., Ingersoll, R.V., 1994. Sandstone petrology and provenance of the Siwalik Group (northwestern Pakistan and western-southeastern Nepal). Journal of Sedimentary Research, A64, 815-823.

Critelli, S., De Rosa, R., Platt, J.P., 1990. Sandstone detrital modes in the Makran accretionary wedge, southwest Pakistan: Implications for tectonic setting and long-distance turbidite transportation. Sedimentary Geology, 68, 241-260.

Debon, F., Le Fort, P., Dautel, D., Sonet, J., Zimmermann, J.L., 1987. Granites of western Karakorum and northern Kohistan (Pakistan): A composite Mid-Cretaceous to upper Cenozoic magmatism. Lithos, 20(1), 19-40.

DeCelles, P., Gehrels, G.E., Quade, J., LaReau, B., Spurlin, M., 2000. Tectonic implications of U$\mathrm{Pb}$ zircon ages of the Himalayan orogenic belt in Nepal. Science, 288, 497-499, doi: 10.1126/science.288.5465.497.

DePaolo, D.J., Wasserburg, G.J., 1976. Nd isotopic variations and petrogenetic models. Geophysical Research Letters, 3, 249-252.

DiPietro, J.A., Pogue, K.R., 2004. Tectonostratigraphic subdivisions of the Himalaya: A view from the west. Tectonics, 23, TC5001, doi:10.1029/2003TC001554.

Dixit, Y., Hodell, D.A., Petrie, C.A., 2014. Abrupt weakening of the summer monsoon in northwest India 4100 yr ago. Geology, 42(4), 339-342, doi:10.1130/G35236.1.

Dhir, R.P., Singhvi, A.K., Andrews, J.E., Kar, A., Sareen, B.K., Tandon, S.K., Kailath, A., Thomas, J.V., 2010. Multiple episodes of aggradation and calcrete formation in late Quaternary aeolian sands, central Thar Desert, Rajasthan, India. Journal of Asian Earth Sciences, 37, 10-16. 
1202

1203

126) 4

4

1255

12706

1207

10

11

1208

1309

155

17

1281

19

12012

21

12213

23

124 14

1295

28

1296

30

13217

32

1328

34

1359

1320

39

1421

41

1422

43

1223

45

$1 \frac{42}{4} 4$

14225

50

15226

52

1527

54

${ }_{56}^{53} 8$

523
58

15930

60

$12 B 1$

62

63

64

65

Downing, K.F., Lindsay, E.H.., 2005. Relationship of Chitarwata Formation paleodrainage and paleoenvironments to Himalayan tectonics and Indus River paleogeography. Palaeontologia Electronica, 8, 1; 20A, 12 p.

East, A.E., Clift, P.D., Carter, A., Alizai, A., Van Laningham, S., 2015. Fluvial-eolian interactions in sediment routing and sedimentary signal buffering: an example from the Indus Basin and Thar Desert. Journal of Sedimentary Research, 85, 715-728.

Enzel, Y., Ely, L.L., Mishra, S., Ramesh, R., Amit, R., Lazar, B., Rajaguru, S.N., Baker, V.R., Sandler, A., 1999. High-resolution Holocene environmental changes in the Thar Desert, northwestern India. Science, 284, 125-128.

Fraser, J.E., Searle, M.P., Parrish, R.R., Noble, S.R., 2001. Chronology of deformation, metamorphism, and magmatism in the southern Karakoram Mountains. Geological Society of America Bulletin, 113 (11), 1443-1455-

Gabriel, K.R., 1971. The biplot graphic display of matrices with application to principal component analysis. Biometrika, 58, 453-467.

Gaetani, M., Garzanti, E., Jadoul, F., Nicora, A., Tintori, A., Pasini, M., Kanwar, S.A.K., 1990, The north Karakorum side of the Central Asia geopuzzle. Geological Society of America Bulletin, $102,54-62$.

Galehouse, J.S., 1971. Point counting, In: Carver, R.E. (ed.), Procedures in sedimentary petrology, New York, Wiley, pp. 385-407.

Garçon, M., Chauvel, C., France-Lanord, C., Limonta, M., Garzanti, E., 2014. Which minerals control the Nd-Hf-Sr-Pb isotopic compositions of river sediments? Chemical Geology, 364, 4255.

Garzanti, E., 2016. From static to dynamic provenance analysis-Sedimentary petrology upgraded. Sedimentary Geology, 336, 3-13.

Garzanti, E., 2017, The maturity myth in sedimentology and provenance analysis. Journal of Sedimentary Research, 87, 353-365.

Garzanti, E., 2019a. The Himalayan foreland basin from collision onset to the present: a sedimentary-petrology perspective. In: Treloar, P., Searle, M.P. (Eds.), Himalayan tectonics: a modern synthesis. Geological Society London, Special Publication 483, 65-122, doi.org: 10.1144/SP483.17 
1232 Garzanti, E., 2019b. Petrographic classification of sand and sandstone. Earth-Science Reviews, 192,

$12 B 3$

2

$12 \frac{3}{4} 4$

$12 \frac{5}{6} 5$

7

12836

1 1DO37

11

12

11238

$1, \frac{1}{12} 39$

16

$1 \frac{17}{18} 40$

12941

20

21

12242

1243 25

$\frac{1394}{27}$

12845

29

30

13446

32

$13-37$

1348 36

1349

38

13250

40

14251

42

1252

$1 \frac{453}{46}$

14254

48

15055

51

15256

1537

55

1558

15259 545-563.

Garzanti, E., Andò, S., 2019. Heavy Minerals for Junior Woodchucks. Minerals, 9, 148, https://doi.org/10.3390/min9030148.

Garzanti, E., Resentini, A., 2016. Provenance control on chemical indices of weathering (Taiwan river sands). Sedimentary Geology, 336, 81-95.

Garzanti, E., Van Haver, T., 1988. The Indus clastics: forearc basin sedimentation in the Ladakh Himalaya (India). Sedimentary Geology, 59(3-4), 237-249.

Garzanti, E., Vezzoli, G., 2003. A classification of metamorphic grains in sands based on their composition and grade Journal of Sedimentary Research, 73, 830-837.

Garzanti, E., Casnedi, R., Jadoul, F., 1986. Sedimentary evidence of a Cambro-Ordovician orogenic event in the northwestern Himalaya. Sedimentary Geology, 48, 237-265.

Garzanti, E., Baud, A., Mascle, G., 1987. Sedimentary record of the northward flight of India and its collision with Eurasia (Ladakh Himalaya, India). Geodinamica Acta, 1, 297-312.

Garzanti, E., Critelli, S., Ingersoll, R.V., 1996. Paleogeographic and paleotectonic evolution of the Himalayan Range as reflected by detrital modes of Tertiary sandstones and modern sands (Indus transect, India and Pakistan). Geological Society of America Bulletin, 108, 631-642.

Garzanti, E., Vezzoli, G., Andò, S., Paparella, P., Clift, P.D., 2005. Petrology of Indus River sands: a key to interpret erosion history of the Western Himalayan Syntaxis. Earth and Planetary Science Letters, 229, 287-302.

Garzanti, E., Andò, S., France-Lanord, C., Vezzoli, G., Najman, Y., 2010. Mineralogical and chemical variability of fluvial sediments. 1. Bedload sand (Ganga-Brahmaputra, Bangladesh). Earth Planetary Science Letters, 299, 368-381.

Garzanti, E., Andò, S., France-Lanord, C., Galy, V., Censi, P., Vignola, P., 2011. Mineralogical and chemical variability of fluvial sediments. 2. Suspended-load silt (Ganga-Brahmaputra, Bangladesh). Earth and Planetary Science Letters, 302, 107-120.

Garzanti, E., Resentini, A., Vezzoli, G., Andò, S., Malusà, M., Padoan, M., 2012. Forward compositional modelling of Alpine orogenic sediments. Sedimentary Geology, 280, 149-164. 
1260 Garzanti, E., Vermeesch, P., Rittner, M. and Simmons, M., 2018. The zircon story of the Nile: 1261 Time- structure maps of source rocks and discontinuous propagation of detrital signals. Basin

Garzanti, E., Andò, S., France-Lanord, C., Limonta, M., Borromeo, L., Vezzoli, G., 2019. Provenance of Bengal Shelf Sediments. 2. Petrology of sand. Minerals, 9, 642; doi:10.3390/min9100642.

Garzanti, E., Andò, S., Vezzoli, G., 2020. Provenance of Cenozoic Indus Fan sediments (IODP Sites U1456 and U1457). Journal of Sedimentary Research, in press.

Gehrels, G.E., DeCelles, P.G., Martin, A., Ojha, T.P., Pinhassi, G., Upreti, B.N., 2003. Initiation of the Himalayan Orogen as an early Paleozoic thin-skinned thrust belt. GSA Today, 13(9), 4-9.

Gehrels, G., Kapp, P., DeCelles, P., Pullen, A., Blakey, R., Weislogel, A., Ding, L., Guynn, J., Martin, A., McQuarrie, N., Yin, A., 2011. Detrital zircon geochronology of pre- Tertiary strata in the Tibetan- Himalayan orogen. Tectonics, 30, TC5016, doi:10.1029/2011TC002868.

Giosan, L., Constantinescu, S., Clift, P.D., Tabrez, A.R., Danish, M., Inam, A., 2006a. Recent morphodynamics of the Indus delta shore and shelf. Continental Shelf Research, 26, 1668-1684.

Giosan, L., Clift, P.D., Blusztajn, J., Tabrez, A., Constantinescu, S., Filip, F., 2006b. On the control of climate- and human-modulated fluvial sediment delivery on river delta development: The Indus. Eos, Transactions, American Geophysical Union, 87, AGU Fall Meeting Abstracts, OS14A-04.

Giosan, L., Clift, P.D., Macklin, M.G., Fuller, D.Q., Constantinescu, S., Durcan, J.A., Stevens, T., Duller, G.A.T., Tabrez, A.R., Gangal, K., Adhikari, R., Alizai, A., Filip, F., Van Laningham, S., Syvitski, J.P.M., 2012. Fluvial landscapes of the Harappan civilization. Proceedings of the National Academy of Sciences, 109, 1688-1694, doi/10.1073/pnas.1112743109.

Gnos, E., Immenhauser, A., Peters, T.J., 1997. Late Cretaceous/early Tertiary convergence between the Indian and Arabian plates recorded in ophiolites and related sediments. Tectonophysics, 271, $1-19$.

Goodbred, S.L., Kuehl, S.A., 2000. Enormous Ganges-Brahmaputra sediment discharge during strengthened early Holocene monsoon. Geology, 28, 1083-1086.

Gosal, G., 2004. Physical geography of the Punjab. Journal of Punjab Studies, 11, 19-37. 
1289

1290

12. 1

1292

6

1293

1294

10

1205

12

1296

14

${ }_{16}^{15} 7$

$1 \frac{13}{18}$

1129) 9

20

21

12300

23

1352

13303

29

1304

31

13205

33

13466

35

$1_{37}^{36} 7$

13308

39

40

14109

42

14310

1431

46

13712

1493

50

51

1524

53

1545

1356

$1_{58}^{57} 17$

59

60

61

62

63

64

65

Greenman, D.W., Swarzenski, W.V., Bennett, G.D., 1967. Ground-water hydrology of the Punjab, West Pakistan, with emphasis on problems caused by canal irrigation. United States Government Printing Office, Washington, United Stated Geological Survey, Water-supply paper 1608H, 166.

Griffin, W.L., Powell, W.J., Pearson, N.J., O'Reilly, S.Y., 2008. GLITTER: data reduction software for laser ablation ICP-MS. In: Sylvester, P. (Ed.), Laser ablation-ICP-MS in the earth sciences: current practices and outstanding issues. Mineralogical Association of Canada, Short Course 40, pp. 204-207.

Hamilton, P.J., O'Nions, R.K., Bridgwater, D., Nutman, A.P., 1983. Sm-Nd studies of Archaean metasediments and metavolcanics from west Greenland and their implications for the Earth's early history. Earth and Planetary Science Letters, 62, 263-272.

Henderson, A.L., Najman, Y., Parrish, R., BouDagher- Fadel, M., Barford, D., Garzanti, E., Andò, S., 2010. Geology of the Cenozoic Indus Basin sedimentary rocks: Paleoenvironmental interpretation of sedimentation from the western Himalaya during the early phases of India- Eurasia collision. Tectonics, 29(6), TC6015, doi:10.1029/2009TC002651.

Hildebrand, P.R., Noble, S.R., Searle, M.P., Waters, D.J., Parrish, R.R., 2001. Old origin for an active mountain range: Geology and geochronology of the eastern Hindu Kush, Pakistan. Geological Society of America Bulletin, 113, 625-639.

Hu, X., Garzanti, E., Moore, T., Raffi, I., 2015. Direct stratigraphic dating of India-Asia collision onset at the Selandian (middle Paleocene, 59 \pm 1 Ma). Geology, 43(10), 859-862.

Hubert, J.F., 1962. A zircon-tourmaline-rutile maturity index and the interdependence of the composition of heavy minerals assemblages with the gross composition and texture of sandstones. Journal of Sedimentary Petrology, 32, 440-450.

Hussain, A., Mir, H., Afzal, M., 2005. Analysis of dust storms frequency over Pakistan during 1961-2000. Pakistan Jounal of Meteorology, 2, 49-68.

Hussain, Y., Ullah, S.F., Hussain, M.B., Aslam, A.Q., Akhter, G., Martinez-Carvajal, H., CárdenasSoto, M., 2017. Modelling the vulnerability of groundwater to contamination in an unconfined alluvial aquifer in Pakistan. Environmental Earth Sciences, 76, 84, doi:10.1007/s12665-0176391-5. 
1318 Ingersoll, R.V., Bullard, T.F., Ford, R.L., Grimm, J.P., Pickle, J.D., Sares, S.W., 1984. The effect of 13119 grain size on detrital modes: a test of the Gazzi-Dickinson point-counting method. Journal of

Jadoon, I.A., Lawrence, R.D., Lillie, R.J., 1994. Seismic data, geometry, evolution, and shortening in the active Sulaiman fold-and-thrust belt of Pakistan, southwest of the Himalayas. American Association of Petroleum Geologists Bulletin, 78, 758-774.

Jagoutz, O.E., Burg, J.P., Hussain, S., Dawood, H., Pettke, T., Iizuka, T., Maruyama, S., 2009. Construction of the granitoid crust of an island arc part I: geochronological and geochemical constraints from the plutonic Kohistan (NW Pakistan). Contributions to Mineralogy and Petrology, 158, 739-755.

Jagoutz, O., Bouilhol, P., Schaltegger, U., Müntener, O., 2019. The isotopic evolution of the Kohistan Ladakh arc from subduction initiation to continent arc collision. In: Treloar, P.J., Searle, M.P. (Eds.), Himalayan Tectonics: A Modern Synthesis. Geological Society, London, Special Publications, 483, 165-182.

Jipa, D., Kidd, R.B., 1974. Sedimentation of coarser grained interbeds in the Arabian Sea and sedimentation processes of the Indus Cone. In: Whitmarsh, R.B., Weser, O.E., Ross, D.A., et al. (Eds.), Initial Report of the Deep Sea Drilling Project 219-230. Washington, D.C., US Government Printing Office, pp. 471-495.

Jonell, T.N., Carter, A., Böning, P., Pahnke, K., Clift, P.D., 2017a. Climatic and glacial impact on erosion patterns and sediment provenance in the Himalayan rain shadow, Zanskar River, NW India. Geological Society of America Bulletin, 129, 820-836.

Jonell, T.N., Owen, L.A., Carter, A., Schwenniger, J. L., Clift, P.D., 2017b. Quantifying episodic erosion and transient storage on the western margin of the Tibetan Plateau, upper Indus River. Quaternary Research, 89(1), 281-306.

Jonell, T.N., Li, Y., Blusztajn, J., Giosan, L., Clift, P.D., 2018. Signal or noise? Isolating grain size effects on $\mathrm{Nd}$ and $\mathrm{Sr}$ isotope variability in Indus delta sediment provenance. Chemical Geology, 485, 56-73.

Kadri, I.B., 1995. Petroleum Geology of Pakistan. Pakistan Petroleum Limited (275 pp.).

Khan, I.A., Bridge, J.S., Kappelman, J., Wilson, R., 1997a. Evolution of Miocene fluvial environments, eastern Potwar plateau, northern Pakistan. Sedimentology, 44, 221-251. 
1348

1349

1350

4

1351

13752

9

1Bक 3

11

1354

135

15

$1 \frac{1356}{35}$

1397

19

20

12558

22

12359

1340

26

12561

28

12362

30

13363

32

13364

34

13555

36

13366

38

13367

40

1468

42

13359

44

14570

46

1471

48

$1 \frac{49}{5} 2$

$1_{52}^{57} 3$

53

15374

55

1565

57

1536

1307

Khan, M.A., Stern, R.J., Gribble, R.F., Windley, B.F., 1997b. Geochemical and isotopic constraints on subduction polarity, magma sources and palaeogeography of the Kohistan intra-oceanic arc, northern Pakistan Himalayas. Journal of the Geological Society, London, 154, 935-946.

Kruskal, J., 1964. Multidimensional scaling by optimizing goodness of fit to a nonmetric hypothesis. Psychometrika, 29, 1-27.

Lee, J.I., Clift, P.D., Layne, G., Blum, J., Khan, A.A., 2003. Sediment flux in the modern Indus River inferred from the trace element composition of detrital amphibole grains. Sedimentary Geology, 160, 243-257.

Li, Y., Clift, P.D., O'Sullivan, P., 2019. Millennial and centennial variations in zircon U- Pb ages ìn the Quaternary Indus submarine canyon. Basin Research, 31, 155-170.

Liang, W., Garzanti, E., Andò, S., Gentile, P., Resentini, A., 2019. Multimineral fingerprinting of Transhimalayan and Himalayan sources to Indus-derived Thal Desert sand (central Pakistan). Minerals, 9, 457, doi:10.3390/min9080457.

Lünsdorf, N.K., Kalies, J., Ahlers, P., Dunkl, I., von Eynatten, H., 2019. Semi-automated heavymineral analysis by Raman spectroscopy. Minerals, 9, 385, doi.org/10.3390/min9070385.

Lupker, M., France-Lanord, C., Galy, V., Lavé, J., Kudrass, H., 2013. Increasing chemical weathering in the Himalayan system since the Last Glacial Maximum. Earth and Planetary Science Letters, 365, 243-252.

Mahar, M.A., Mahéo, G., Goodell, P.C., Pavlis, T.L., 2014. Age and origin of post collision Baltoro granites, south Karakoram, North Pakistan: Insights from in-situ U-Pb, Hf and oxygen isotopic record of zircons. Lithos, 205, 341-358.

Mahéo, G., Blichert-Toft, J., Pin, C., Guillot, S., Pêcher, A., 2009. Partial melting of mantle and crustal sources beneath South Karakorum, Pakistan: Implications for the Miocene geodynamic evolution of the India-Asia convergence zone. Journal of Petrology, 50, 427-449.

Mallik, T.K., 1978, Mineralogy of deep-sea sands of the Indian Ocean. Marine Geology, 27, 161176.

Malusà, M.G., Resentini, A., Garzanti, E., 2016. Hydraulic sorting and mineral fertility bias in detrital geochronology. Gondwana Research, 31, 1-19.

Mange, M.A., Maurer, H.F.W., 1992, Heavy minerals in colour. Chapman and Hall, London. (147 pp.). 
1378

13179

1330

4

$13 \frac{5}{6} 1$

13782

9

$1 B 83$

11

1384

1335

15

1366

13887

19

12388

21

22

12389

12300

$1_{2}^{2} 1$

1382

29

30

13293

32

13394

34
1355 36

1376

3897

40

1498

42

43

1499

14500

14701

49

15102

51

$15+23$

53

1544

15505

15406

59

60

61

62

63

64

65

Mange, M.A., Morton, A.C., 2007. Geochemistry of heavy minerals. In: Mange, M.A., Wright, D.T. (Eds.), Heavy Minerals in Use. Elsevier, Amsterdam, Developments in Sedimentology, 58, pp. 345-391.

Meadows, A., Meadows, P., 1999. The Indus River: Biodiversity, Resources, Humankind. Oxford University Press (441 pp.).

Miller, C., Klötzli, U., Frank, W., Thöni, M., Grasemann, B., 2000. Proterozoic crustal evolution in the NW Himalaya (India) as recorded by circa $1.80 \mathrm{Ga}$ mafic and $1.84 \mathrm{Ga}$ granitic magmatism. Precambrian Research, 103(3-4), 191-206.

Miller, C., Thöni, M., Frank, W., Grasemann, B., Klötzli, U., Guntli, P., Draganits, E., 2001. The early Palaeozoic magmatic event in the Northwest Himalaya, India: source, tectonic setting and age of emplacement. Geological Magazine, 138(3), 237-251.

Milliman, J.D., Quraishee, G.S. Beg, M.A.A., 1984. Sediment discharge from the Indus River to the ocean: past, present, and future. In: Haq, B.U., Milliman, J.D. (Eds.), Marine Geology and Oceanography of the Arabian Sea and Coastal Pakistan. Van Nostrand Reynolds, New York, pp. $65-70$.

Munack, H., Korup, O., Resentini, A., Limonta, M., Garzanti, E., Blöthe, J.H., Scherler, D., Wittmann, H., Kubik, P.W., 2014. Postglacial denudation of western Tibetan Plateau margin outpaced by long-term exhumation. Geological Society of America Bulletin, 126, 1580-1594.

Najman, Y., Garzanti, E., Pringle, M., Bickle, M., Stix, J., Khan, I., 2003. Early-Middle Miocene paleodrainage and tectonics in the Pakistan Himalaya. Geological Society of America Bulletin, 115, 1265-1277.

Nickson, R.T., McArthur, J.M., Shrestha, B., Kyaw-Myint, T.O., Lowry, D., 2005. Arsenic and other drinking water quality issues, Muzaffargarh District, Pakistan. Applied Geochemistry, 20, $55-68$.

Pandey, D.K., Clift, P.D., Kulhanek, D.K. \& Expedition 355 Scientists, 2016. Expedition 355 summary. Arabian Sea Monsoon. In: Pandey, D.K., Clift, P.D., Kulhanek, D.K. \& Expedition 355 Scientists (Eds.), Expedition 355 Scientific Prospectus: Arabian Sea Monsoon. Proceedings of the International Ocean Discovery Program, Volume 355. International Ocean Discovery Program, College Station, TX, 1-32, https://doi.org/10.14379/iodp.proc.355.101.2016. 
1407

1408

$\stackrel{2}{14999}$

4

$14 \frac{5}{6} 0$

$14_{8}^{71} 1$

1492

10

1 141 3

12

13

1444

$1 \frac{15}{16} 5$

14716

19

129 7

21

126ㄹ 8

23

1250

27

12821

29

30

13世区2

32

1323

34

$1 \frac{35}{36} 4$

13325

13926

40

41

14227

43

1428

1459

47

14830

49

151031

51

15632

53

1,533

15934

15835

59

161036

61

62

63

64

65

Parrish, R.R., Hodges, V., 1996. Isotopic constraints on the age and provenance of the Lesser and Greater Himalayan sequences, Nepalese Himalaya. Geological Society of America Bulletin,108, 904-911.

Pêcher, A., Seeber, L., Guillot, S., Jouanne, F., Kausar, A., Latif, M., Majid, A., Mahéo, G., Mugnier, J.L., Rolland, Y., van der Beek, P., Van Melle, J., 2008. Stress field evolution in the northwest Himalayan syntaxis, northern Pakistan. Tectonics, 27, TC6005, doi:10.1029/2007TC002252.

Petterson, M.G., M.B. Crawford, B.F. Windley, 1993. Petrogenetic implications of neodymium isotope data from the Kohistan Batholith, North Pakistan, Journal of the Geological Society, London, 150, 125-129.

Prasad, B.R., Klemperer, S.L., Rao, V.V., Tewari, H.C., Khare, P., 2011. Crustal structure beneath the Sub-Himalayan fold-thrust belt, Kangra recess, northwest India, from seismic reflection profiling: Implications for Late Paleoproterozoic orogenesis and modern earthquake hazard. Earth and Planetary Science Letters, 308(1-2), 218-228.

Prasad, S., Enzel, Y., 2006. Holocene palaeoclimates of India. Quaternary Research, 66, 442-453.

Qayyum, M., Lawrence, R.D., Niem, A.R., 1997. Discovery of the palaeo-Indus delta-fan complex. Journal of the Geological Society London, 154, 753-756, doi: 10.1144/gsjgs.154.5.0753.

Ravikant, V., Wu, F.Y., Ji, W.Q., 2009. Zircon U-Pb and Hf isotopic constraints on petrogenesis of the Cretaceous-Tertiary granites in eastern Karakoram and Ladakh, India. Lithos, 110(1-4), 153166.

Rehman, S.S., Sabir, M.A., Khan, J., 1997. Discharge characteristics and suspended load from rivers of Northern Indus Basin, Pakistan. Geological Bulletin University of Peshawar, 30, 325336.

Resentini, A., Goren, L., Castelltort, S., Garzanti, E., 2017. Partitioning the sediment flux by provenance and tracing erosion patterns in Taiwan. Journal Geophysical Research - Earth Surface, 122, 1430-1454, doi:10.1002/2016JF004026.

Roddaz, M., Said, A., Guillot, S., Antoine, P.O., Montel, J.M., Martin, F., Darrozes, J., 2011. Provenance of Cenozoic sedimentary rocks from the Sulaiman fold and thrust belt, Pakistan: implications for the palaeogeography of the Indus drainage system. Journal of the Geological Society, 168, 499-516. 
1437

$14 B 8$

1439

4

$1 \frac{54}{6} 0$

1441

1442

10

11

11243

13

1144

$\frac{15}{16} 5$

14746

19

12아7

21

121248

23

1249

25

12450

12951

29

13152

31

32

13153

$1 \frac{34}{35} 4$

13555

38

13956

40

14!57

42

1438

44

1459

14760

48

49

15151

51

15262

53

15463

55

1564

15865

Rolland, Y., Mahéo, G., Guillot, S., Pêcher, A., 2001. Tectono-metamorphic evolution of the Karakorum metamorphic complex (Dassu-Askole area, NE Pakistan): exhumation of mid-crustal HT-MP gneisses in a convergent context. Journal of Metamorphic Geology, 19, 717-737.

Rolland, Y., Picard, C., Pêcher, A., Lapierre, H., Bosch, D., Keller, F., 2002. The Cretaceous Ladakh arc of NW himalaya-slab melting and melt-mantle interaction during fast northward drift of Indian Plate. Chemical Geology, 182, 139-178.

Roy, P.D., Nagar, Y.C., Juyal, N., Smykatz-Kloss, W., Singhvi, A.K., 2009. Geochemical signatures of Late Holocene paleohydrological changes from Phulera and Pokharan saline playas near the eastern and western margins of the Thar Desert, India. Journal of Asian Earth Sciences $34,275-286$.

Rudnick, R.L., Gao, S., 2003. Composition of the continental crust. In: Rudnick, R.L., Holland, H.D., Turekian, K.K. (Eds.), Treatise on Geochemistry, The Crust. Elsevier Pergamon, Oxford, UK, Vol. 3, pp. 1-64.

Schärer, U., Copeland, P., Harrison, T. M., Searle, M.P., 1990. Age, cooling history, and origin of post-collisional leucogranites in the Karakoram Batholith; a multi-system isotope study. The Journal of Geology, 98(2), 233-251.

Schaltegger, U., Zeilinger, G., Frank, M., Burg, J.P., 2002. Multiple mantle sources during island arc magmatism: $\mathrm{U}-\mathrm{Pb}$ and $\mathrm{Hf}$ isotopic evidence from the Kohistan arc complex, Pakistan. Terra Nova, 14(6), 461-468.

Schneider, D.A., Zeitler, P.K., Kidd, W.S.F., Edwards, M.A., 2001. Geochronologic constraints on the tectonic evolution and exhumation of Nanga Parbat, western Himalaya syntaxis, revisited. The Journal of Geology, 109, 563-583.

Searle, M.P., 2013. Colliding continents: a geological exploration of the Himalaya, Karakoram, and Tibet. Oxford University Press, Oxford UK, 438 p.

Searle, M.P., Khan, M.A., Fraser, J.E., Gough, S.J., Jan, M.Q., 1999. The tectonic evolution of the Kohistan- Karakoram collision belt along the Karakoram Highway transect, north Pakistan. Tectonics, 18, 929-949.

Searle, M.P., Parrish, R.R., Thow, A.V., Noble, S.R., Phillips, R.J., Waters, D.J., 2010. Anatomy, age and evolution of a collisional mountain belt: the Baltoro granite batholith and Karakoram 
1466

1467

2

14488 5

1489

$14 \% 0$ 9
10

1표1

12

$1+432$ 14

$\frac{15}{16} 3$

1474

18

11495

20

21

12426

14 377

$1 \frac{25}{26} 8$

27

12899

29

13180

31

$13+21$

33

13482

13683

13484

39

14185

41

14286

43

14587

1488

48

1489

50

15490

52

$15+91$

54

15592

15493

15994 4

60

61

62

63

64

65

Shah, S.M.I., 1977. Stratigraphy of Pakistan. Geological Survey of Pakistan, Memoir, 12, 138 p.

Shah, Z.U.H., Ahmad, Z., 2015. Hydrochemical mapping of the Upper Thal Doab (Pakistan) using the geographic information system. Environmental Earth Sciences, 74, 2757-2773.

Shah, Z.U.H., Ahmad, Z., 2016. Hydrogeology and hydrochemistry of the Upper Thal Doab (Pakistan). Environmental Earth Sciences, 75(6), 527, doi: 10.1007/s12665-015-5211-z.

Shroder, J.F., Bishop, M.P., 2000. Unroofing of Nanga Parbat Himalaya. In: Khan M.A., Treloar P.J., Searle M.P., Jan M.Q. (Eds.), Tectonics of the Nanga Parbat Syntaxis and the Western Himalaya. Geological Society, London, Special Publication, 170, pp. 163-179.

Singh, G., Wasson, R.J., Agrawal, D.P., 1990. Vegetational and seasonal climatic changes since the last full glacial in the Thar Desert, northwestern India. Review of Palaeobotany and Palynology, 64(1-4), 351-358.

Singh, S., Kumar, R., Barley, M.E., Jain, A.K., 2007. SHRIMP U-Pb ages and depth of emplacement of Ladakh Batholith, Eastern Ladakh, India. Journal of Asian Earth Sciences, 30(34), 490-503.

Singh, S., Jain, A.K., Barley, M.E., 2009. SHRIMP U-Pb c.1860 Ma anorogenic magmatic signatures from the NW Himalaya: implications for Palaeoproterozoic assembly of the Columbia Supercontinent. In: Reddy, S.M., Mazumder, R., Evans, D.A.D., Collins, A.S. (Eds.), Palaeoproterozoic Supercontinents and Global Evolution. Geological Society, London, Special Publications, 323, 283-300.

Singhvi, A. K., Kar, A., 2004. The aeolian sedimentation record of the Thar Desert. Journal of Earth System Science, 113, 371-401.

Singhvi, A.K., Williams, M.A.J., Rajaguru, S.N., Misra, V.N., Chawla, S., Stokes, S., Chauhan, N., Francis, T., Ganjoo, R.K., Humphreys, G.S., 2010. A 200 ka record of climatic change and dune activity in the Thar Desert, India. Quaternary Science Reviews, 29, 3095-3105.

Staubwasser, M., Sirocko, F., Grootes, P.M., Erlenkeuser, H., 2002. South Asian monsoon climate change and radiocarbon in the Arabian Sea during early and middle Holocene. Paleoceanography, 17(4), 1063, doi:10.1029/2000PA000608. 
1495 St-Onge, M.R., Rayner, N., Searle, M.P., 2010. Zircon age determinations for the Ladakh batholith 1496 at Chumathang (Northwest India): Implications for the age of the India-Asia collision in the

Suczek, C.A., Ingersoll, R.V., 1985. Petrology and provenance of Cenozoic sand from the Indus Cone and the Arabian Basin, DSDP sites 221, 222, and 224. Journal of Sedimentary Petrology, 55(3), 340-346.

Tate, E.L., Farquharson, F.K., 2000. Simulating reservoir management under the threat of sedimentation: The case of Tarbela Dam on the River Indus. Water Resources Management, 14 191-208.

Taylor, S.R., McLennan, S.M., 1995. The geochemical evolution of the continental crust. Review of Geophysics, 33, 241-265.

Treloar, P.J., Petterson, M.G., Jan, M.Q., Sullivan, M.A., 1996. A re-evaluation of the stratigraphy and evolution of the Kohistan arc sequence, Pakistan Himalaya: implications for magmatic and tectonic arc-building processes. Journal of the Geological Society London, 153, 681-693.

Vermeesch, P., 2012. On the visualisation of detrital age distributions. Chemical Geology, 312, 190-194.

Vermeesch, P., 2013. Multi-sample comparison of detrital age distributions. Chemical Geology, 341, 140-146.

Vermeesch, P., 2018. Dissimilarity measures in detrital geochronology. Earth-Science Reviews, $178,310-321$.

Vermeesch, P., Garzanti, E., 2015. Making geological sense of 'Big Data' in sedimentary provenance analysis. Chemical Geology, 409, 20-27.

Vermeesch, P., Resentini, A., Garzanti, E., 2016. An R package for statistical provenance analysis. Sedimentary Geology, 336, 14-25.

Vermeesch, P., Rittner, M., Petrou, E., Omma, J., Mattinson, C., Garzanti, E., 2017. High throughput petrochronology and sedimentary provenance analysis by automated phase mapping and LAICPMS. Geochemistry, Geophysics, Geosystems, 18, 4096-4109, doi: 10.1002/2017GC007109. 
1523

$15 \mathrm{R} 4$

1525

4

$15 \frac{5}{6} 6$

1527

1598

10

11

1529

1530

15

$1 \frac{15}{17} 1$

15932

19

13033

21

12534

23

$1 \frac{24}{25} 5$

1356

15897

29

13038

31

32

13339

13540 36

13741

13942

40

1543

42

43

1544

$1 \frac{45}{46}$

4746
48

15947

50

51

15248

53

1549

1550

15751

59

1552

61

62

63

64

65

Von Eynatten, H., Pawlowsky-Glahn, V., Egozcue, J.J., 2002. Understanding perturbation on the simplex: A simple method to better visualize and interpret compositional data in ternary diagrams. Mathematical Geology, 34(3), 249-257.

Weinberg, R.F., Dunlap, W.J., 2000. Growth and deformation of the Ladakh Batholith, Northwest Himalayas: implications for timing of continental collision and origin of calc-alkaline batholiths. The Journal of Geology, 108, 303-320.

Whittington, A., Foster, G., Harris, N., Vance, D., Ayres, M., 1999. Lithostratigraphic correlations in the western Himalaya; an isotopic approach. Geology 27, 585-588.

Whittington, A., Harris, N.B.W., Ayres, M.W., Foster, G., 2000. Tracing the origins of the western Himalaya: an isotopic comparison of the Nanga Parbat massif and Zanskar Himalaya. In: Khan, M.A., Treloar, P.J., Searle, M.P., Jan, M.Q. (Eds.), Tectonics of the Nanga Parbat Syntaxis and the Western Himalaya. Geological Society, London, Special Publications, 170, pp. 201-218.

Yu, Z., Colin, C., Wan, S., Saraswat, R., Song, L., Xu, Z., Clift, P.D., Lu, H., Lyle, M., Kulhanek, D., Hahn, A., Tiwari, M., Mishra, R., Miska, S., Kumar, A., 2019. Sea level-controlled sediment transport to the eastern Arabian Sea over the past 600 kyr: Clay minerals and SrNd isotopic evidence from IODP site U1457. Quaternary Science Reviews, 205, 22-34.

Zeitler, P.K., Chamberlain, C.P., Smith, H.A., 1993. Synchronous anatexis, metamorphism, and rapid denudation at Nanga Parbat (Pakistan Himalaya). Geology, 21, 347-350.

Zeitler, P.K., Meltzer, A.S., Koons, P.O., Craw, D., Hallet, B., Chamberlain, C.P., Kidd, W.S., Park, S.K., Seeber, L., Bishop, M., Shroder, J., 2001. Erosion, Himalayan geodynamics, and the geomorphology of metamorphism. GSA Today, 11, 4-9.

Zhuang, G., Najman, Y., Guillot, S., Roddaz, M., Antoine, P.O., Métais, G., Carter, A., Marivaux, L., Solangi, S.H., 2015. Constraints on the collision and the pre-collision tectonic configuration between India and Asia from detrital geochronology, thermochronology, and geochemistry studies in the lower Indus basin, Pakistan. Earth and Planetary Science Letters, 432, 363-373.

Zhuang, G., Najman, Y., Tian, Y., Carter, A., Gemignani, L., Wijbrans, J., Jan, M.Q., Khan, M.A., 2018. Insights into the evolution of the Hindu Kush-Kohistan-Karakoram from modern river sand detrital geo-and thermochronological studies. Journal of the Geological Society London, 175(6), 934-948. 
1553

1

2

3

4

7

8

10

11

12

13

14

15

16

17

18

19

20

21

22

23

24

25

26

27

28

29

30

31

32

33

34

35

36

37

38

39

40

41

42

43

44

45

46

47

48

49

50

51

52

53

54

55

56

57

58

59

60

61

62

63

64

65 


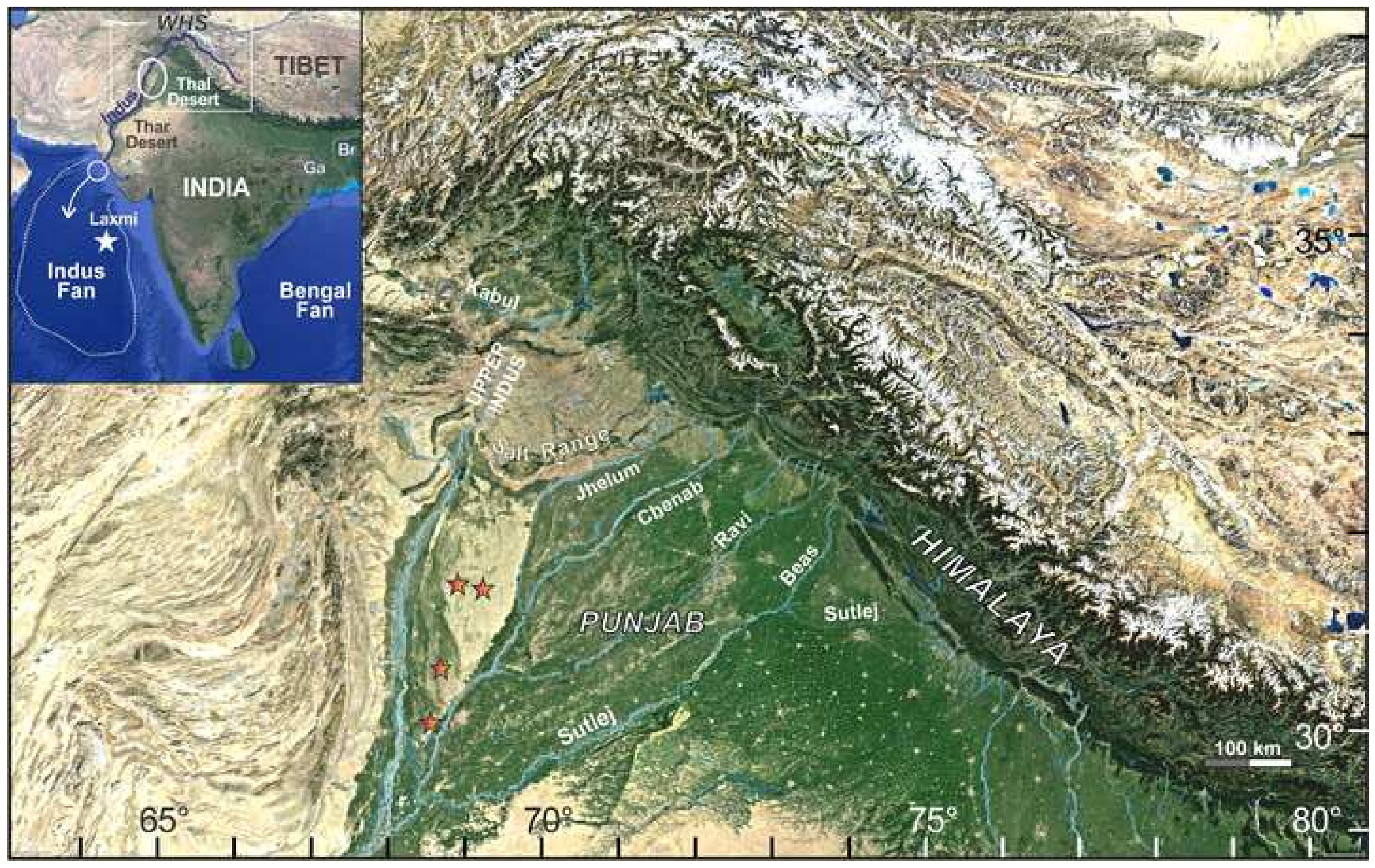




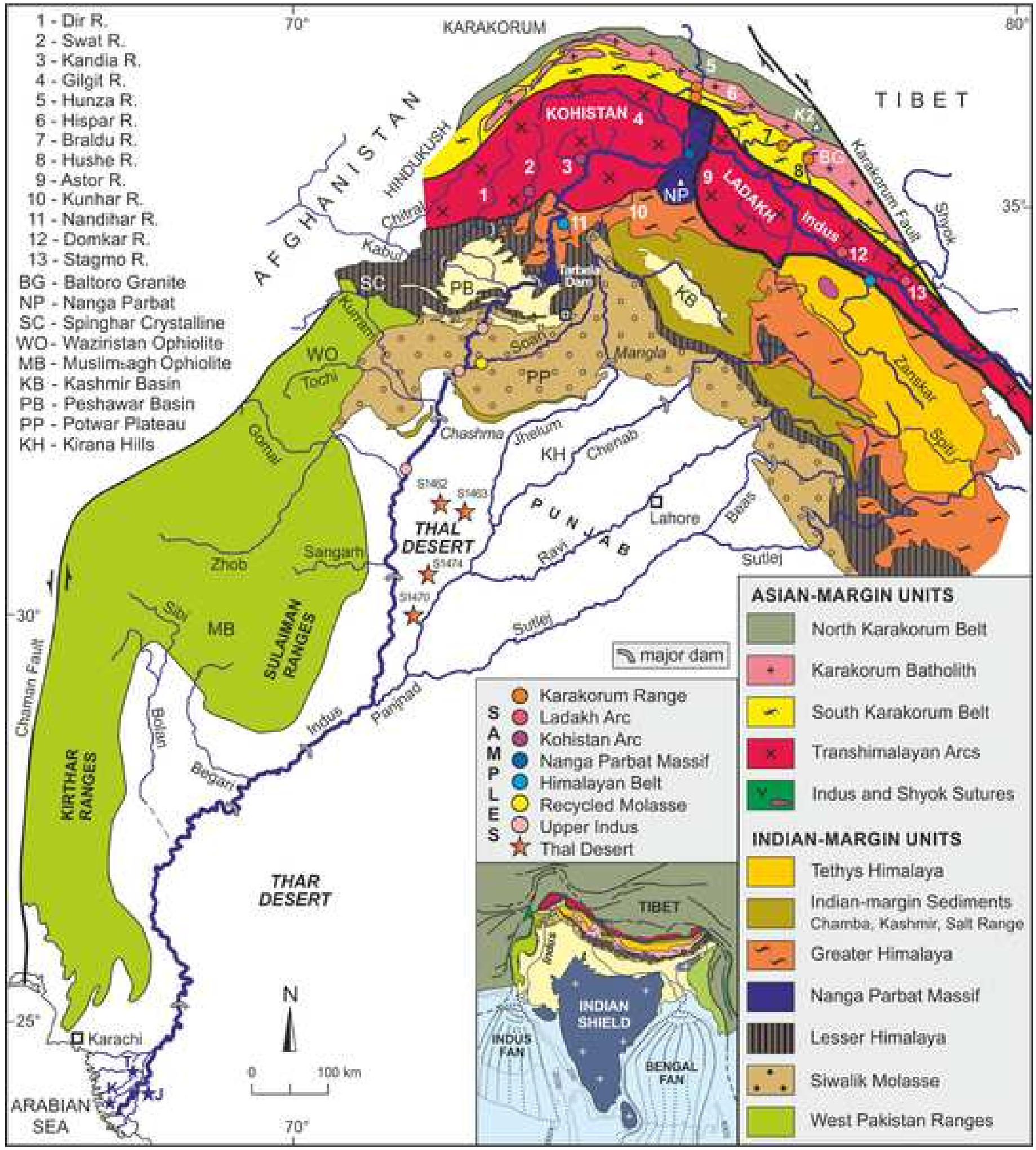



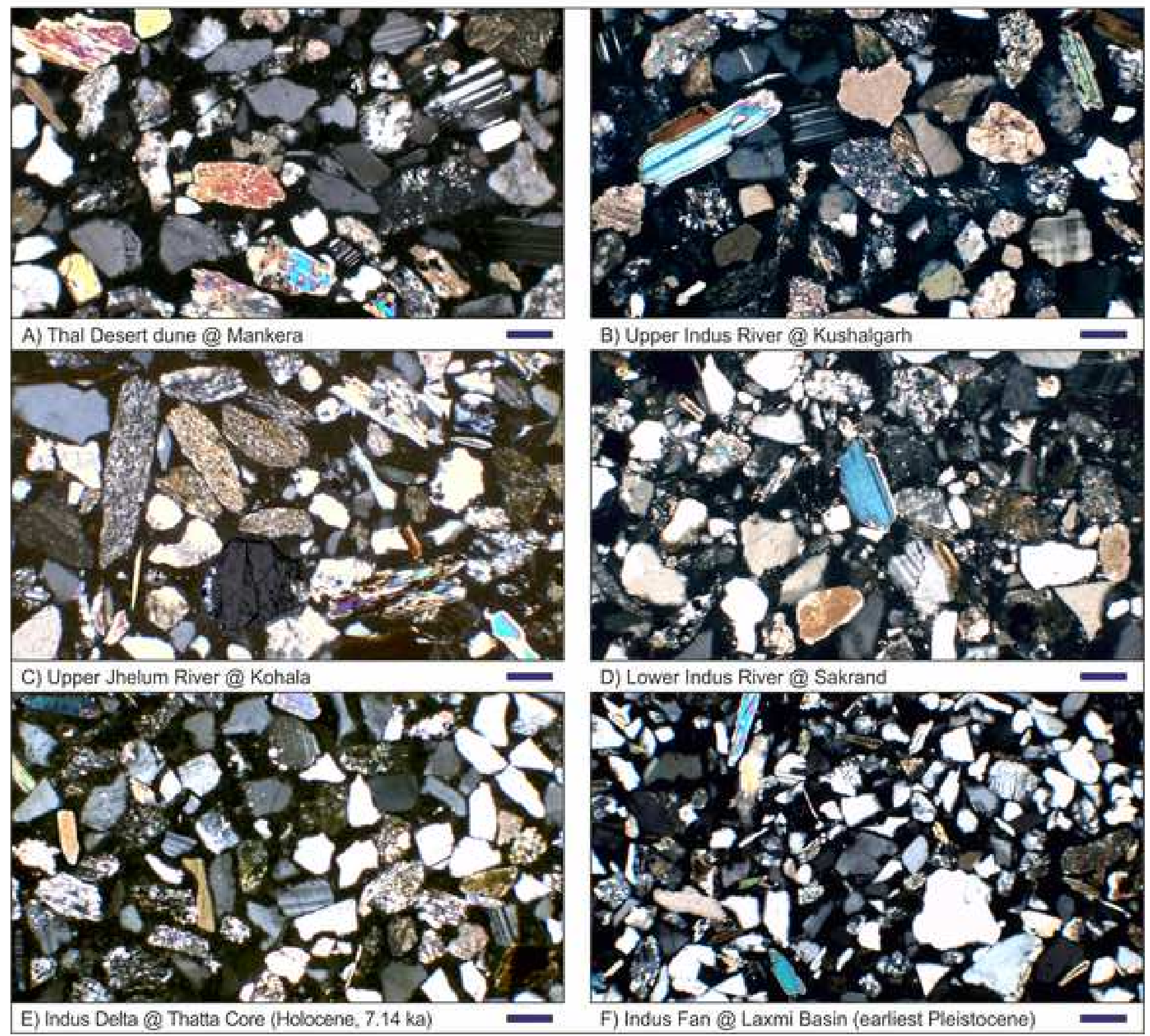


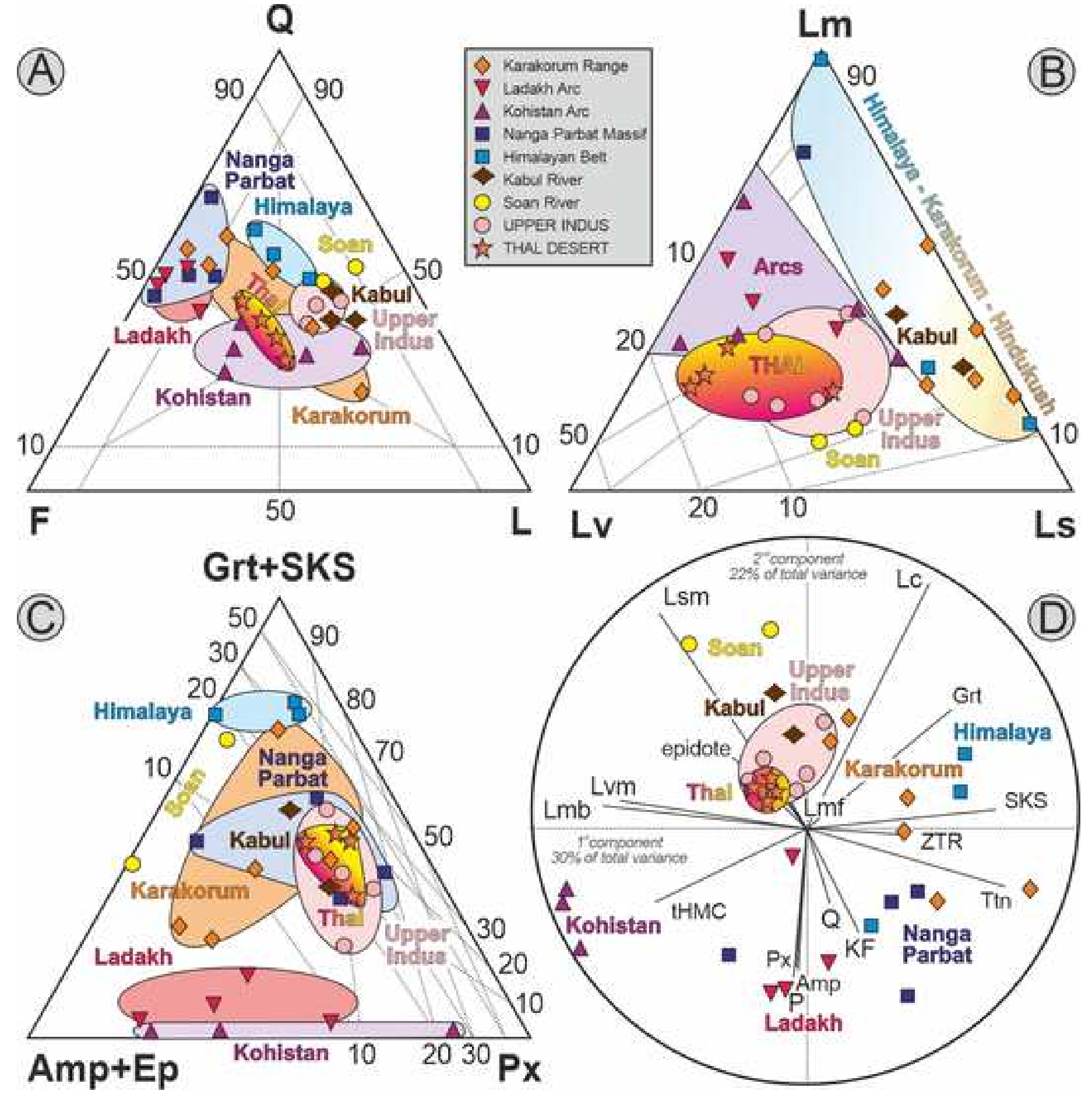




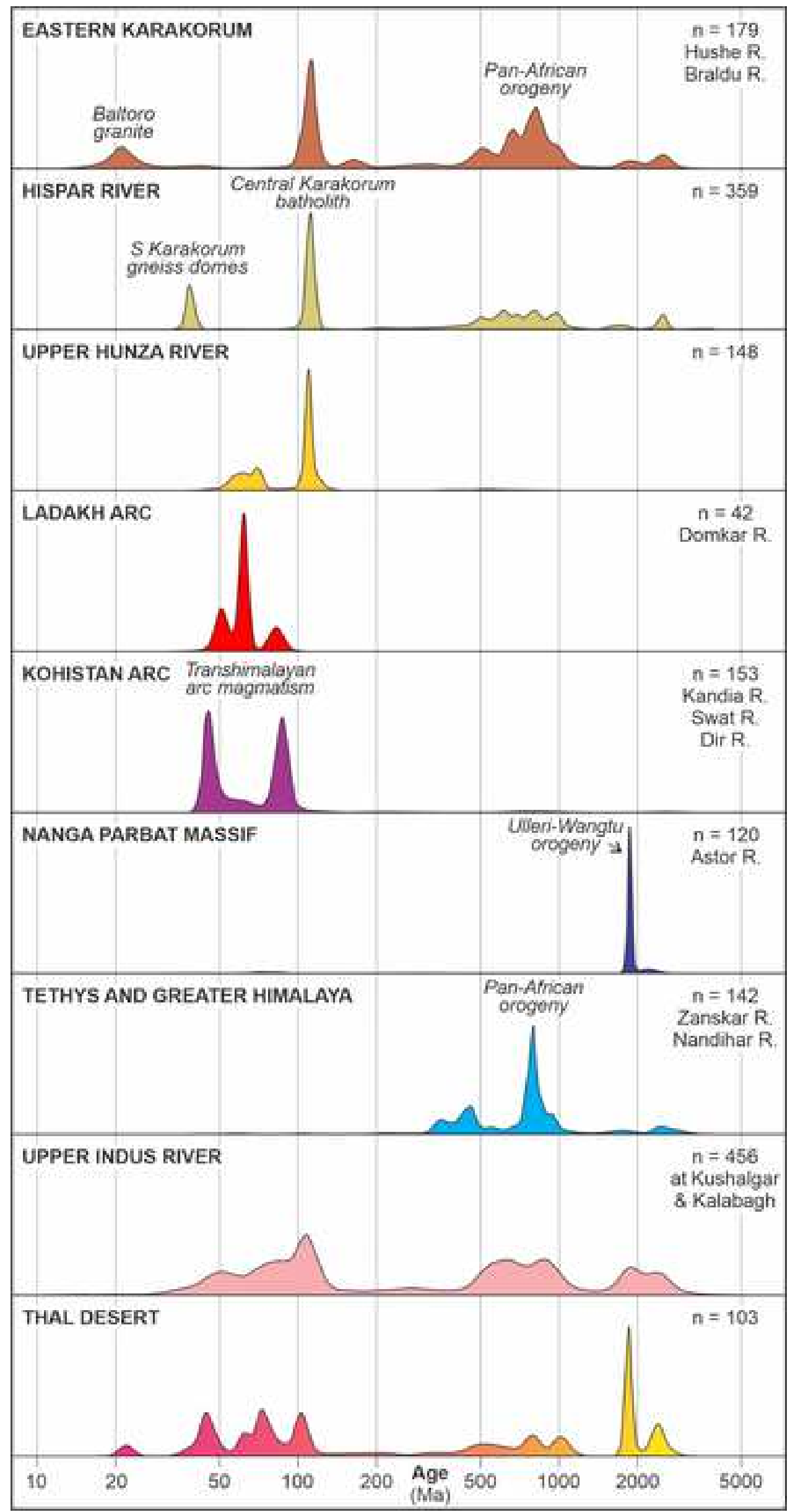




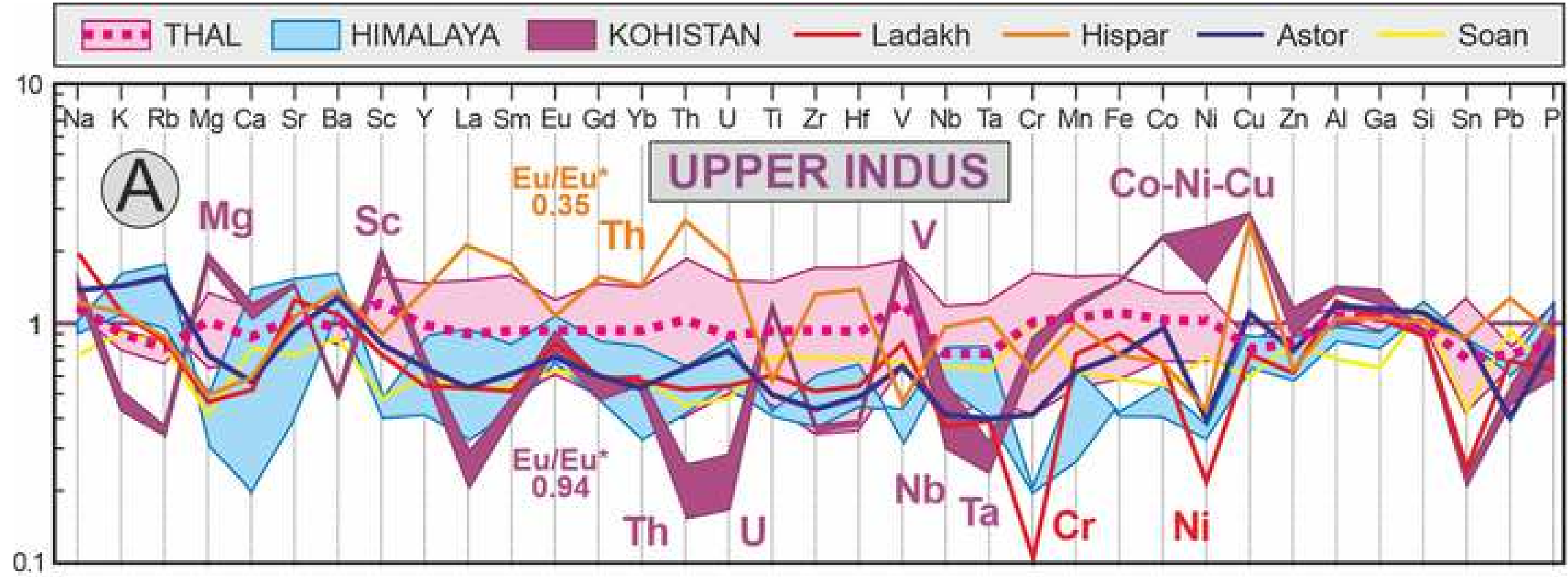

1

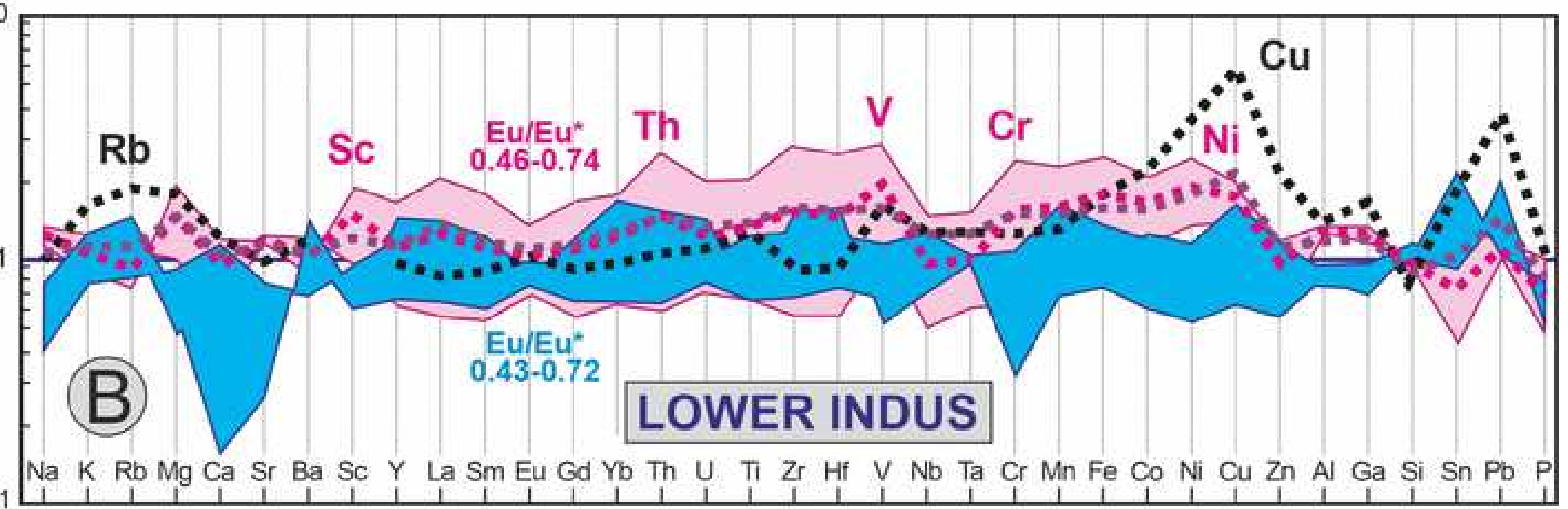

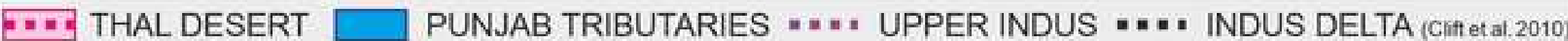




\section{EPIDOTE}

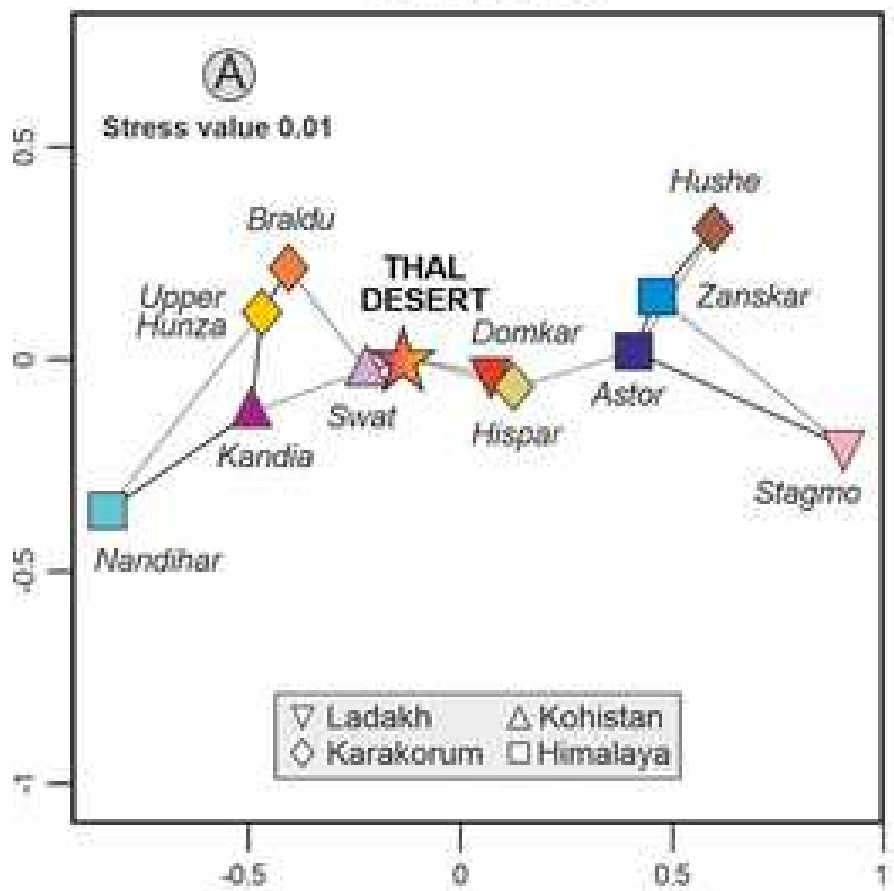

AMPHIBOLE

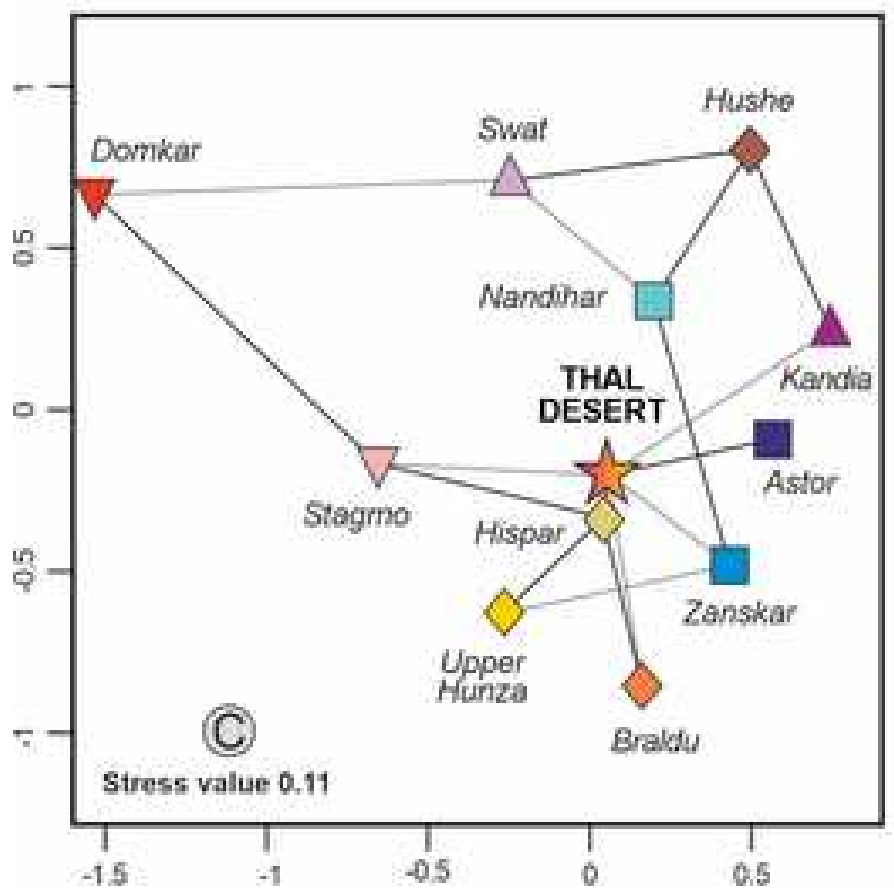

PYROXENE

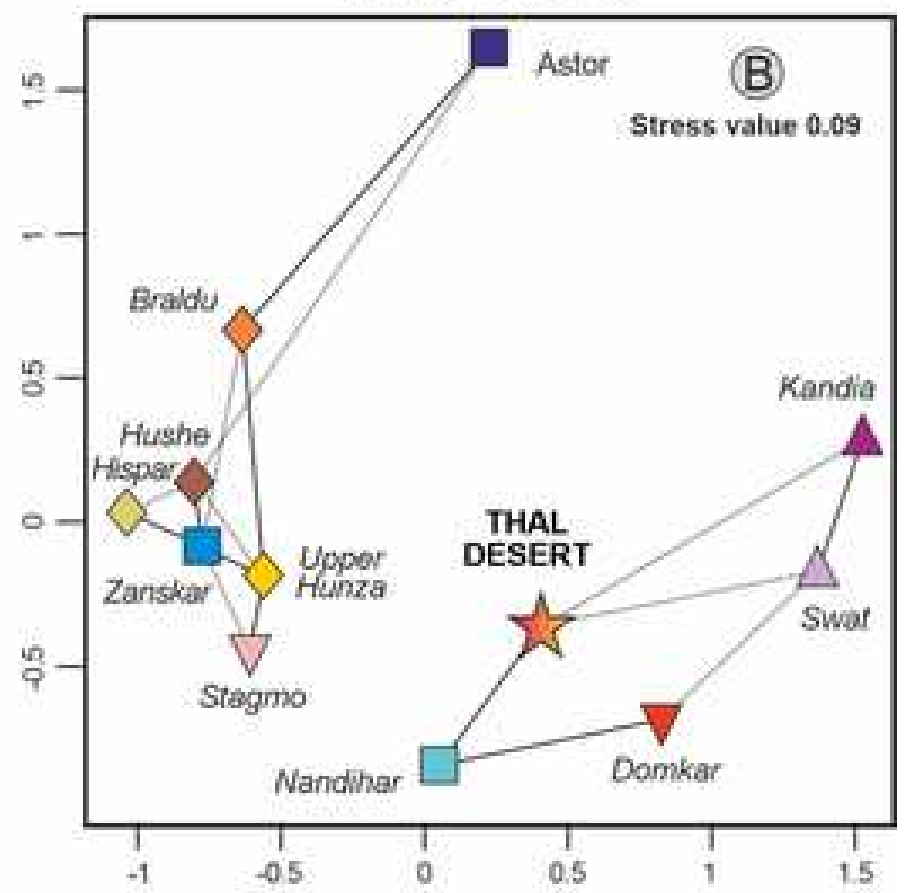

GARNET

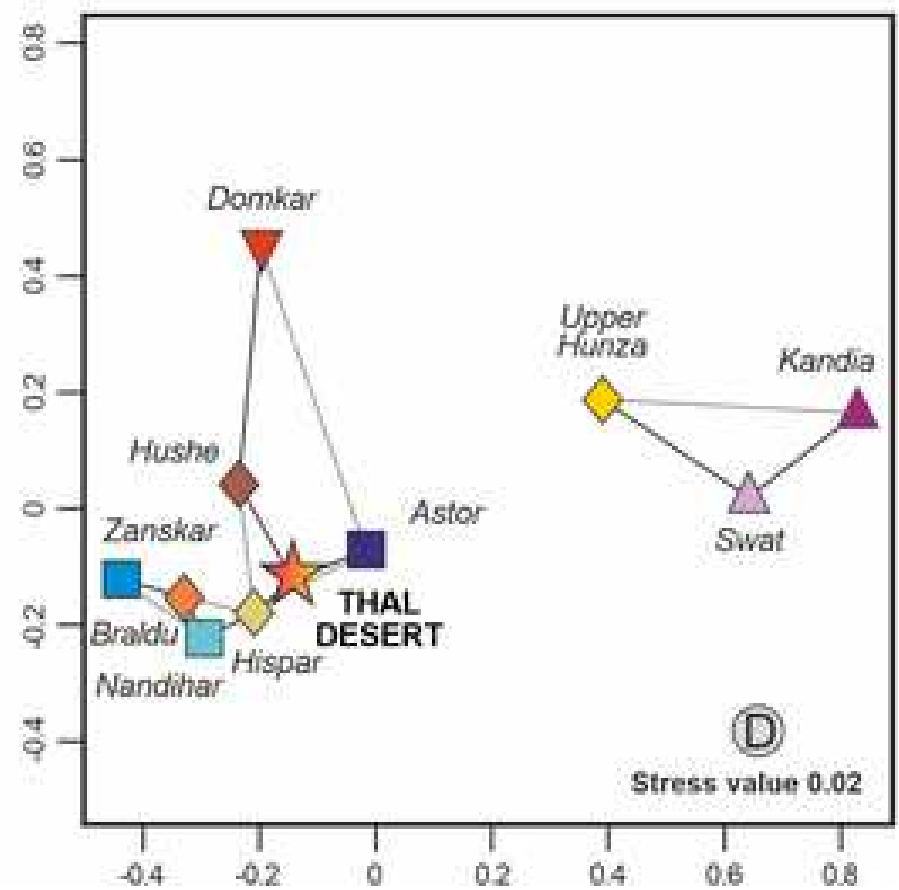



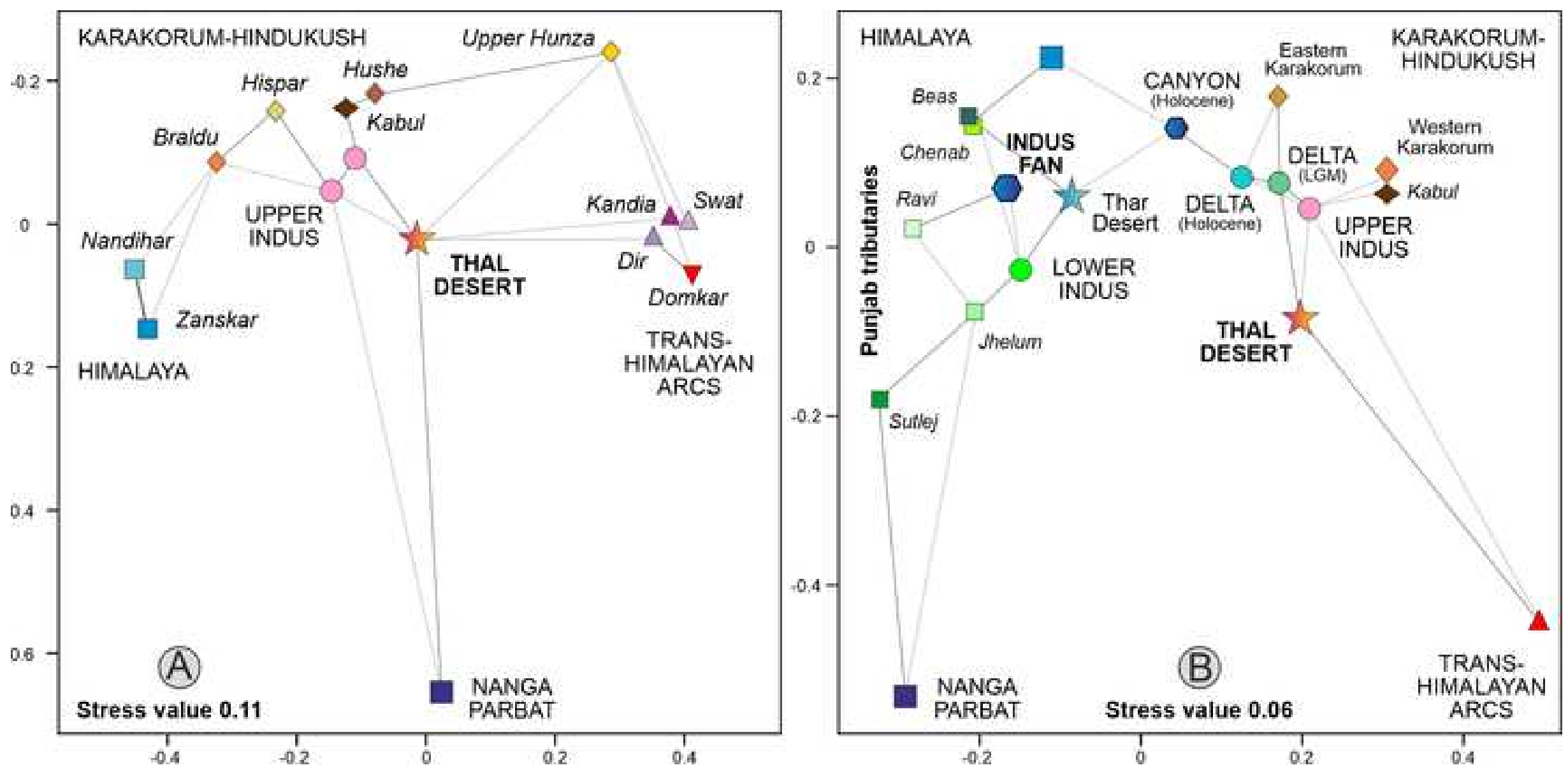

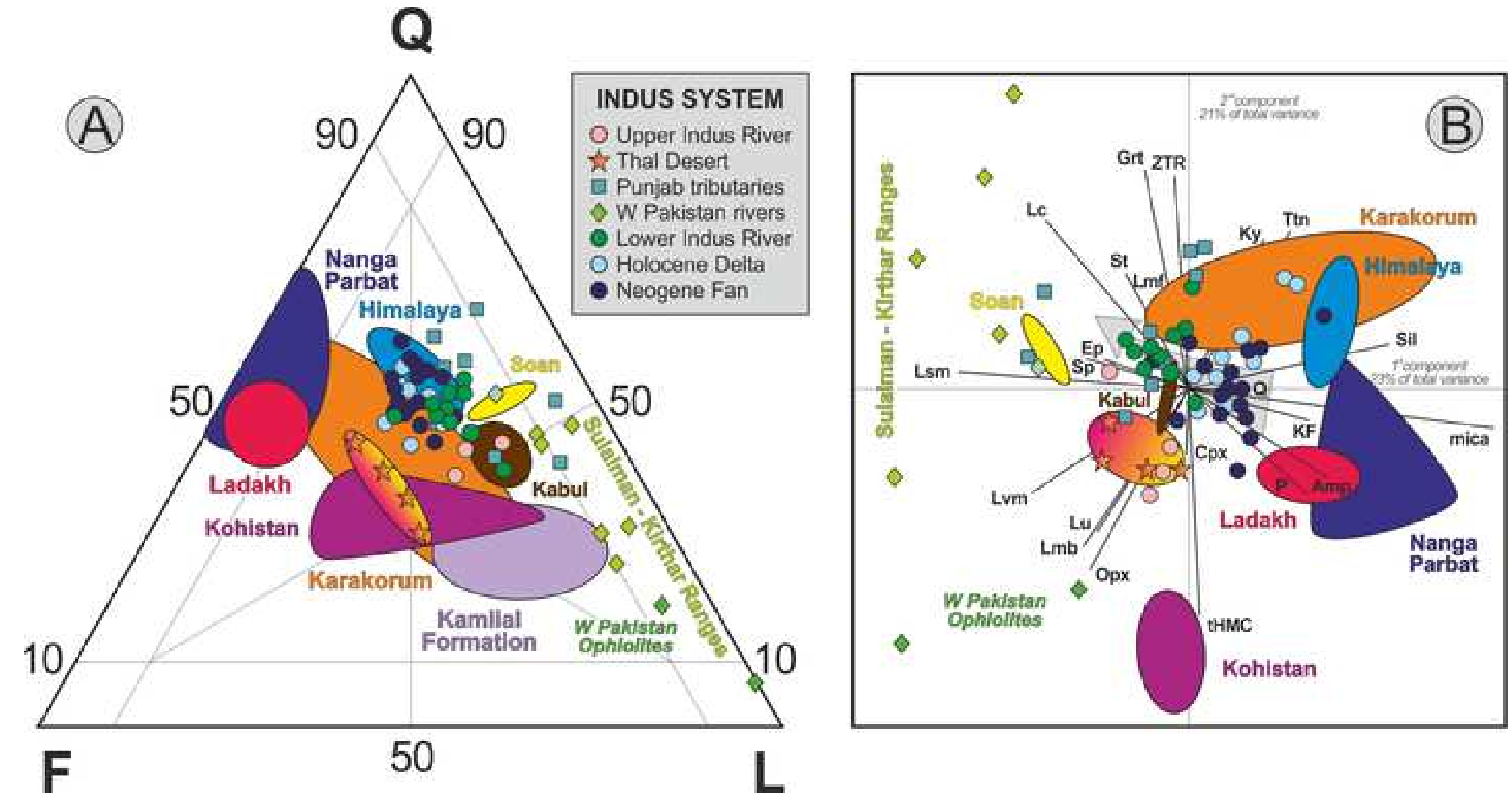

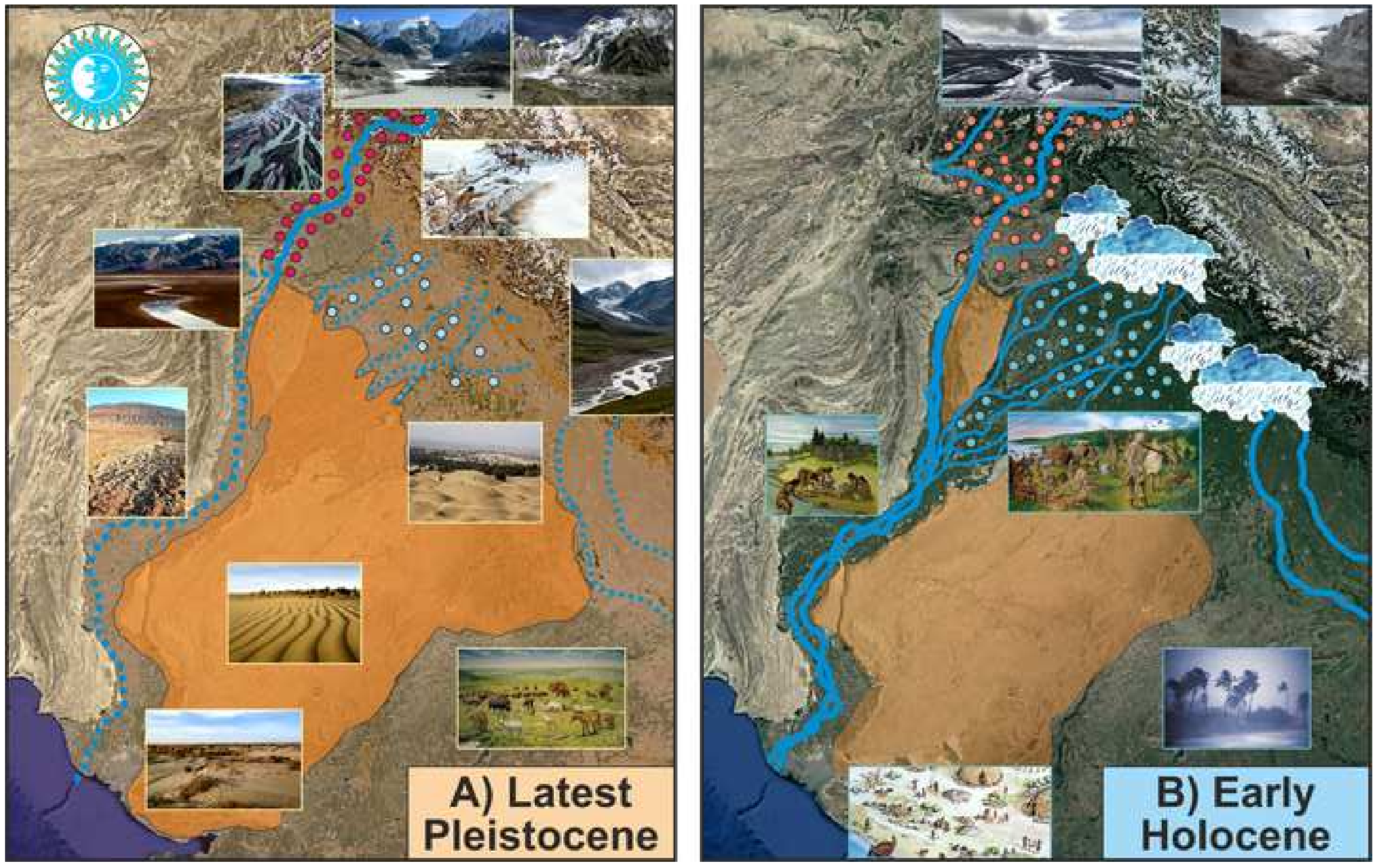